\title{
Fee Sharing Between Lawyers and Public Interest Groups
}

\author{
Roy D. Simon, Jr.†
}

Table of Contents

INTRODUCTION

I. History and Scope of the Rule Against FeE SHARING

A. History of the Rule Against Fee Sharing 1076

B. Scope of the Rule Against Fee Sharing 1083

C. Exceptions to the Rule

1. Are Public Interest Groups "Law Firms"?

2. Compensation Plans for Nonlawyer Employees

3. Referral Fees

II. The Effect of the Federal Fee-Shifting Statutes 1091

A. The Supremacy Clause 1091

B. Separate Litigation Funds 1095

1. National Treasury Employees Union and Its Progeny 1095

2. Evaluating the Separate Litigation Fund Concept

3. Opinions Going Beyond NTEU 1101

III. Should the Bar Greate an Exception? 1104

A. The State's Interests: The Seven Deadly Sins 1105

1. Eliminating Incentives for Nonlawyers to Stir Up Litigation 1105

2. Preventing Improper Methods of Solicitation by Nonlawyers

3. Preventing Unauthorized Practice of Law 1107

† Associate Professor of Law, Washington University in St. Louis. The author is grateful to his Washington University colleagues Lee Benham, Merton Bernstein, Dan Ellis, Jules Gerard, Mike Greenfield, Bill Jones, Bruce La Pierre, Steve Legornsky, Ron Levin, Dan Mandelker, Frank Miller, Tom Sullivan, Dale Swihart, and Bob Thompson, who substantially improved earlier drafts. He also is grateful to the Executive Committee of the Washington University Law Alumni Association for its generous financial support, and to his diligent Research Assistants David Bachman '88, Stephen Potts '88, David Lundgren ' 89 , and Michael Garvin ' 89 . The author is a member of the Board of Trustees of the ACLU of Eastern Missouri, but the views expressed here are entirely his own. 
4. Preventing Excessive Fees

5. Preventing Referrals to Incompetent Lawyers 1108

6. Preventing Unethical Practices in Litigation 1109

7. Protecting the Attorney-Client Relationship 1110

B. Countervailing Interests: The Value of Public Interest Groups

IV. Do Lawyers Have a First Amendment Right to Share Market Rate Fees with Public Interest ORGANIZATIONS?

A. The First Amendment and Group Legal Services

B. Policies Underlying the Group Legal Services Cases

1. Low-Cost Legal Services

2. Political Expression for Minorities

G. The Constitutional Test

1. Compelling State Interests

2. Precision of Regulation

\section{INTRODUCTION}

Attorney fees awarded to prevailing plaintiffs by statute ${ }^{1}$ are a significant source of funding for nonprofit public interest groups that sponsor litigation..$^{2}$ Nearly all such organizations require staff attorneys ${ }^{3}$ to turn

1. A prevailing civil rights plaintiff, for example, is ordinarily entitled to an award of reasonable attorney fees. See Civil Rights Attorney's Fees Awards Act of 1976, 42 U.S.C. $§ 1988$ (1982) (providing that court may, in its discretion, award "reasonable attorney's fee" to prevailing party). A plaintiff is entitled to the award unless "special circumstances" would make an award of fees unjust. Newman v. Piggie Park Enters., 390 U.S. 400, 402 (1968).

Dozens of other federal statutes-concerning such diverse areas as the environment, voting rights, employment discrimination, and rights of the handicapped-also entitle a prevailing plaintiff to reasonable attorney fees. See Marek v. Chesny, 473 U.S. 1, 43-51 (1985) (appendix to Brennan, J., dissenting). The standards developed for section 1988 awards "are generally applicable in all cases in which Congress has authorized an award of fees to a "prevailing party." "Hensley v. Eckerhart, 461 U.S. 424, 433 n.7 (1983). This Article therefore uses section 1988 to illustrate the principles of statutory attorney fees in public interest cases.

2. In this Article, the term "public interest groups" contemplates groups that share two characteristics: (1) they are nonprofit entities holding tax-exempt status under sections 501(c)(3) or 501(c)(4) of the Internal Revenue Code, and (2) they finance or provide lawyers for public interest litigation that can result in statutory fee awards. There is no set agreement on the meaning of public interest litigation, but the Council For Public Interest Law (now the Alliance for Justice) has defined "public interest law" as:

efforts to provide legal representation to previously unrepresented groups and interests. Such efforts have been undertaken in recognition that the ordinary marketplace for legal services fails to provide such services to significant segments of the population and to significant interests. Such groups and interests include the poor, environmentalists, consumers, racial and ethnic minorities, and others.

Council For Public Interest law, Balancing the Scales of Justice: Financing Public INTEREST LAW IN AMERICA 6-7 (1976). Examples of public interest groups include the American Civil Liberties Union (ACLU), the National Association for the Advancement of Colored People (NAACP), and the Mexican-American Legal Defense and Educational Fund. This Article is not 
over all court-awarded fees to the organization, and many organizations require cooperating attorneys ${ }^{4}$ to turn over all or part of any fees resulting from cases sponsored by the organizations. Yet a rule of legal ethics that prohibits lawyers from sharing legal fees with nonlawyers ${ }^{8}$ may jeopardize this important source of funding. This Article explores whether the rule against fee sharing with nonlawyers can or should be enforced against lawyers who agree to assign statutory legal fees to nonprofit public interest groups.

The problem is not merely theoretical. I recently conducted an empirical survey on the fee-sharing practices of public interest groups, ${ }^{6}$ and I

directly concerned with legal aid societies or with offices of the Legal Services Corporation, which are essentially law firms for indigents and unquestionably can receive fees based on work done by their lawyers. See Blum v. Stenson, 465 U.S. 886, 890-92, 902 (1984) (affirming market rate fee award to Legal Aid Society of New York).

3. The term "staff attorneys" refers to full-time salaried employees of public interest organizations who work only on matters referred or assigned to them by the organizations. Not all public interest groups employ staff attorneys. I recently surveyed a wide range of public interest groups, see infra note 6 , and learned that about $50 \%$ of all state ACLU affiliates and about $15 \%$ of other public interest groups do not employ any staff attorneys.

4. The term "cooperating attorneys" refers to private lawyers who agree to handle matters for public interest organizations without salary. According to a recent survey of public interest law groups, more than three-fourths of such groups call upon cooperating attorneys to handle at least some of their litigation, and these cooperating attorneys performed, on the average, $28 \%$ of the legal work undertaken by the surveyed groups. See N. ARON, LIBERTY AND JusTiCE FOR ALL: PUBLIC INTEREST LAW IN THE 1980'S AND BEYOND 33 (1989) (summarizing staffing patterns in public interest law).

5. The rule provides:

(a) A lawyer or law firm shall not share legal fees with a nonlawyer, except that:

(1) an agreement by a lawyer with the lawyer's firm, partner, or associate may provide for

the payment of money, over a reasonable period of time after the lawyer's death, to the law-

yer's estate or to one or more specified persons;

(2) a lawyer who undertakes to complete unfinished legal business of a deceased lawyer may

pay to the estate of the deceased lawyer that proportion of the total compensation which fairly represents the services rendered by the deceased lawyer; and

(3) a lawyer or law firm may include nonlawyer employees in a compensation or retirement plan, even though the plan is based in whole or in part on a profit-sharing arrangement.

Model Rules of Professional Conduct Rule 5.4(a) (1987) [hereinafter Model Rules]; see also Model Code of Professional Responsibility DR 3-102(A) (1986) [hereinafter Model CODE] (identical in all relevant respects). Approximately 30 states have thus far adopted the Model Rules in some form. See [Manual] Law. Man. on Prof. Conduct (ABA/BNA) 01:3-01:4 (1988) (listing states that have adopted the Model Rules through July 1988). Most of the remaining states continue to base their rules of legal ethics on the Model Code.

6. In December 1987 and January 1988, I sent questionnaires to every chapter and affiliate of the ACLU, and to dozens of other public interest organizations that finance or conduct litigation. I agreed to keep the identities of the specific respondents confidential unless they gave me permission to disclose their names. I have the survey results on file.

The ACLU list was prepared by the ACLU's National Office in New York City in July 1987, and included addresses for all of the ACLU's affiliates, chapters, regional offices, and projects. See ACLU Affiliate List (on file with author). I received 52 responses from the ACLU mailing.

I created a list of non-ACLU public interest groups by studying the Encyclopedia of Associations. ENCYCLOPEDIA OF Associations (22d ed. 1988). I reviewed every entry under relevant headings (Attorneys, Civil Rights, Law, Legal Aid, Litigation, and Public Interest) for organizations which might sponsor or conduct public interest litigation. My final mailing list included more than 75 public interest organizations, including the Washington Legal Foundation, the Center for Public Representation, the Center for Law in the Public Interest, the Women's Law Project, and the NAACP Legal Defense and Education Fund, Inc. I received 42 responses, and 26 organizations said they provided lawyers or financial support for litigation that could lead to court-awarded fees. 
received a number of anecdotal reports that lawyers and bar committees are applying the fee-sharing prohibition against public interest organizations. One ACLU affiliate that recently began requiring cooperating attorneys to share fees reported that "several cooperating attorneys have raised concerns about sharing fees." Another AGLU affiliate said: "We have had at least two cooperating attorneys refuse to turn over fees. We were unable to collect our share, even after complaining to the State Bar in one case." At a third, a former staff attorney has retained fees on grounds that turning over the fees would violate the fee-sharing rule. ${ }^{7}$ Another ACLU affiliate recently settled a dispute with a cooperating law firm that reneged on an agreement to share half of its court-awarded fees. And in Maine, the Professional Ethics Commission formally ruled that a cooperating attorney's agreement to turn over a specified percentage of the fees to a foundation connected with the state's ACLU affiliate violated the fee-sharing rule because it "would involve splitting legal fees with a nonlawyer."

Organizations other than the ACLU also have had problems with the fee-sharing rule. In a widely publicized case, the NAAGP Special Contribution Fund filed suit against four of its former staff attorneys, seeking to recover more than two million dollars in fees awarded to the defendants when they were full-time salaried employees of the NAACP. ${ }^{9}$ The former staff lawyers argue that the rule against fee sharing prohibits them from turning over their fees to a nonlawyer group such as the NAACP. ${ }^{10}$ The

There are undoubtedly many groups that I did not contact. Some groups are not listed in the Encyclopedia of Associations or any other standard source, and new groups form all the time. See, e.g., Whistleblower Forms Foundation for Protection, L.A. Daily J., July 18, 1988, at 5, col. 1 (new foundation, currently seeking tax-exempt status from IRS, intends to "set up a network of attorneys to provide free legal aid for whistleblowers").

7. The former staff attorney, who recently entered private practice, received a $\$ 30,000$ fee award based on work done as a full-time staff attorney, but retained $\$ 10,000$ for herself. She has argued, among other things, that the organization failed to maintain the kind of separate litigation fund described in National Treasury Employees Union v. Department of the Treasury, 656 F.2d 848 (D.C. Cir. 1981) (discussed infra at notes 146-58 and accompanying text). She has not fully explained why she gave the remaining $\$ 20,000$ of the fee award to the organization. The affiliate has now filed suit to recover the $\$ 10,000$ in fees thus far retained by the attorney. Telephone interviews with the Executive Director of the affiliate (June 29, 1988 \& March 27, 1989).

8. Maine Comm'n on Professional Ethics, Op. 69, at 2 (1986) (on file with author). The Commission commented that cases awarding fees directly to public interest litigation organizations (PILO's) had "no relevance to whether an attorney and PILO can agree to split legal fees awarded to the attorney by a court." Id. at 2 n.2. But a concurring opinion argued that a court-awarded fee belonged to the client, not to the attorney, and that the fee-sharing rule "cannot prohibit an agreement for division of a fee award between client and PILO." Id. at 3-4 (concurring opinion).

9. See NAACP-Special Contribution Fund v. Atkins, No. 87-0156-CV-W-6 (W.D. Mo. amended complaint filed Mar. 10, 1988) (suit filed to recover fees awarded in Ohio desegregation case and other cases sponsored by NAACP). The NAACP Special Contribution Fund is an unincorporated association affiliated with the NAACP. It is tax exempt under section 501(c)(3) of the Internal Revenue Code, so contributions to it are tax deductible. It was formed in the early 1960's, when the NAACP itself was not qualified under section $501(\mathrm{c})(3)$ to receive tax-deductible contributions. A majority of the board of the Fund consists of nonlawyers. Telephone interview with Grover Hankin, NAACP General Counsel (March 28, 1989).

10. See generally N.A.A.C.P. Sues Four of its Former Lawyers, N.Y. Times, Feb. 22, 1987, at 
case is still in the early stages. Another group reported that the federal government had once challenged the group's right to get fees, and had dropped the issue only after learning that the organization was chartered as a legal aid organization under state law. ${ }^{11}$

On the other hand, several bar associations have formally approved policies that require attorneys to turn over court-awarded attorney fees to public interest groups. In 1979, the Bar Association of Greater Cleveland ruled that staff attorneys and cooperating attorneys for a nonprofit group dedicated to securing full legal rights for women could ethically agree to remit to the organization all fees awarded in sponsored matters. ${ }^{12}$ In 1984, the Nebraska State Bar approved the local ACLU's policy of requiring cooperating attorneys to turn over thirty-five percent of all court-awarded fees to the ACLU for deposit into a fund used solely for litigation. ${ }^{13}$ Early in 1989, the Florida Bar ruled that the ACLU of Florida could ethically require cooperating and staff attorneys to share all or part of their courtawarded fees with the ACLU for deposit into a fund used exclusively for litigation purposes. ${ }^{14}$

These conflicting anecdotal data suggest that questions about the feesharing rule are likely to continue arising in public interest litigation until there is a definitive interpretation of the rule. This uncertainty is of con-

23, col. 1. As this Article is being written, the lawyers are still skirmishing over jurisdiction and other preliminary issues. See NAACP-Special Contribution Fund v. Atkins, No. 87-0156-CV-W-6 (W.D. Mo. Mar. 14, 1989) (order granting motion to dismiss claim against Atkins without prejudice, and giving parties 30 days to file joint motions for such alternatives as dismissals without prejudice or stay of proceedings while certain claims are severed and transferred); see also In re NAACP, Special Contribution Fund, Nos. 87-3366 \& 87-3673 (6th Cir. June 13, 1988) (WESTLAW, CTA6 database) (reversing district court's order enjoining prosecution of Missouri suit).

11. The group also reported that more than half the members of its Board of Directors were lawyers. The identity of the group is confidential.

12. Bar Ass'n of Greater Cleveland Professional Ethics Comm., Op. 141 (June 21, 1979) (on file with author) (holding that staff attorney could agree to remit fees as condition of employment).

13. See Letter from George Green, President, Nebraska Civil Liberties Union, to Robert Barlow, Advisory Opinion Comm., Nebraska State Bar Ass'n (July 9, 1984) (on file with author) (setting forth group's policy and requesting ruling); Letter from John Taylor, Executive Director, Nebraska Civil Liberties Union (undated) (on file with author) (stating that Nebraska State Bar had approved Nebraska Civil Liberties Union's policy as stated in George Green's letter).

14. Letter from Patricia Allen, Ethics Counsel, The Florida Bar, to Larry Spalding, Past President, ACLU of Florida (January 19, 1989) (on file with author) (attaching letter of query from ACLU and reporting that Florida Bar's Professional Ethics Committee voted on January 11, 1989, with one dissent, that ACLU's policies regarding fees awarded to cooperating and staff attorneys "do not involve fee-splitting"). The Ethics Committee did not issue a written opinion, but Ms. Allen's letter elaborated on its decision:

Because the arrangements you describe do not involve fee-splitting, Rule 4-5.4(a) is inapplica-

ble. In other words, . . . attorneys who join together with nonprofit civil rights organizations

to furnish legal assistance to aggrieved parties are not ethically obligated to accept or keep all or, for that matter, any part, of the fee that may be awarded.

Only seven months earlier, however, an Assistant Ethics Counsel for the Florida Bar had written the ACLU a preliminary opinion that "any arrangement or agreement by the [ACLU's cooperating] attorneys to give a portion of court-awarded fees to the organization would be prohibited." Letter from Kathy Papantonio to James Green, ACLU of Florida (June 28, 1988) (on file with author) (emphasis in original): But Ms. Papantonio went on to state: "If individual attorneys desire to make donations to the organization, unrelated to any legal fees awarded, however, they may do so." Id. (emphasis in original). 
siderable significance to public interest groups. According to a recently published survey, court-awarded attorney fees generated by staff attorneys and cooperating attorneys account for about nine percent of all income to public interest groups that sponsor litigation. ${ }^{15}$ Given the continuing proliferation of fee-shifting statutes ${ }^{16}$ and the decline in foundation support and private donations, ${ }^{17}$ attorney fee awards are likely to become even more significant.

Staff attorneys are an especially important source of fees. Virtually every public interest organization requires its staff attorneys to turn over all court-awarded fees. ${ }^{18}$ These fees finance many litigation activities that do not generate fees, including cases that are settled before any suit is filed, cases in which the sponsored client is a defendant, administrative matters for which fees are not available, cases in which the organization is an amicus rather than a party, and cases in which the sponsored client does not prevail. In addition, fee awards finance such things as educational activities, client screening, capital improvements, policy development, scholarships, recruitment and training programs, supervision of cooperating attorneys, and general overhead expenses.

If states were to strictly enforce the fee-sharing prohibition against staff attorneys for public interest organizations, the impact on public interest litigation would be severe. In the ACLU, over forty-two percent of the affiliates say they "could not employ any staff lawyers," and over thirtysix percent "could not afford to employ as many staff attorneys" as they do now. Only twenty-one percent say they could keep all of their present

15. N. ARON, supra note 4, at 39-40 \& 46 table 2.6 (reporting on results of 1983-84 survey). My survey showed that about $40 \%$ of all ACLU affiliates and other public interest groups have derived more than $10 \%$ of their income between 1983 and 1988 from fee awards.

16. In comparison with past decades, increasing numbers of cases sponsored by public interest groups are eligible for fee awards. Congress passed "a great spate" of new fee-shifting statutes during the 1970's. See M. Derfner \& A. Wolf, 1 Court Awarded Atrorney Fees II 1.02, at 1-27 to 128 (1988). In the 1980 's, Congress has focused on passing fee-shifting laws increasing the availability of fee awards in litigation against federal administrative agencies. See id. at 1-28.

17. One survey of foundation support for public interest law shows that the average group experienced a $36 \%$ decline in foundation funds between 1975 and 1983. See N. ARON, supra note 4, at 51-52. More recent statistics about foundation donations to equal rights and legal services groups show that a four year increase in both the dollar value and number of grants reported was reversed in 1986. See Clinton, Trends in Foundation Giving, in The Foundation Directory xxxi, xxxiii (11th ed. 1987); see also O'Connor \& Epstein, Rebalancing the Scales of Justice: Assessment of Public Interest Law, 7 HaRv. J.L. \& PuB. PoL'y 483, 502 (1984) ("While funds for conservatives have increased rapidly, those earmarked for liberal public interest law are in decline." (footnote omitted)); Walker, The Role of Foundations in Helping to Reach the Civil Rights Goals of the 1980's, 37 RUTGers L. Rev. 1055, 1056-57 (1985) (discussing "harsh reality" that substantial cutbacks in federal assistance to nonprofit groups will confront foundations with "difficult funding choices in the years ahead").

To compound the decline in foundation grants, individual charitable giving has recently begun to level off. See Cox, New Figures Show Growth In Donations Has Slackened, Wall St. J., June 13, $1988, \S 2$, at 19 , col. 5 (new study shows that individual giving is growing more slowly than in past years).

18. Among the ACLU groups employing staff attorneys, 25 of 26 require staff attorneys to turn over all fees. Among the other groups in my survey, all but one required staff attorneys to turn over all court-awarded fees. Not surprisingly, no group allowed staff attorneys to keep all fees. 
staff lawyers. The answers from organizations other than the ACLU were equally pessimistic. Nearly one-third say they could not employ any staff attorneys if staff attorneys did not turn over all fees, and another third could not employ as many staff attorneys as they do now. ("Or we might fold," added one group.) Less than thirty-eight percent say they could continue to employ all of their staff lawyers. ${ }^{18}$

Cutting back on staff attorneys would strike at the nerve center of public interest litigation. Staff attorneys develop expertise in an organization's area of law; they understand and are committed to the group's goals and policies; they are readily available to screen and handle cases; and they are uniquely qualified to help the group in selecting, monitoring, and training cooperating lawyers. ${ }^{20}$ Allowing public interest groups to share fees based on work done by staff and cooperating attorneys is thus important to the continued vitality of public interest litigation. But does the ethical prohibition against fee sharing between lawyers and nonlawyers stand in the way?

The issue is not whether public interest groups are entitled to reimbursement for providing legal services. The law is settled that an attorney who personally receives a fee award must reimburse the organization for its actual out-of-pocket costs in furnishing the lawyer's services. ${ }^{21}$ Nor is the issue whether attorneys may donate fees to public interest organizations; the rule against fee sharing in no way prohibits attorneys from making charitable contributions. ${ }^{22}$ Yet voluntary donations cannot substitute for contractual agreements to share fees. Donations simply would not yield as much money. A staff attorney would have little incentive to donate fees to an organization after leaving its employ. A cooperating attorney might keep fees to cover overhead relating to a case. Even attorneys

19. One of the most interesting comments came from an organization that said it could afford to keep all of its present staff attorneys, but said it "would take fewer high risk cases." Since risky cases are more likely to result in a loss-and thus in a financial loss to the organization because expenses are not reimbursed-many other organizations might also become more cautious in their case selection, avoiding cases that could succeed only by breaking new legal ground.

20. In particular, staff attorneys can serve as co-counsel in sponsored cases, whereas a group's lay employees obviously cannot. Having staff attorneys serve as co-counsel ensures that clients and cooperating attorneys consider the public interest implications of sponsored cases, and also ensures that the group will be kept informed of all developments in each case. For this reason, many ACLU affiliates require that clients and cooperating attorneys allow their staff attorneys to serve as co-counsel in all cases sponsored by the group. See, e.g., ACLU of Louisiana Cooperating Attorney Agreement 2 (May 25,1988 ) (on file with author) (ACLU General Counsel's name and title must be on all pleadings); ACLU of Maryland Agreement 2 (undated) (on file with author) ("An ACLU staff attorney will appear as 'Of Counsel' on all papers filed by the Lawyer(s)."); ACLU of New Mexico Guidelines for Cooperating Attorneys 2 (Nov. 1986) (on file with author) ("Legal Director's name is to be listed underneath that of the cooperating attorney" on all pleadings).

21. See Wilderness Soc'y v. Morton, 495 F.2d 1026 (D.C. Cir. 1974) (en banc) (reimbursing nonprofit organization for out-of-pocket expenses does not violate prohibition against fee sharing) (discussed infra at text accompanying notes 115-21), rev'd on other grounds sub nom. Alyeska Pipeline Serv. Co. v. Wilderness Soc'y, 421 U.S. 240 (1975); infra note 121 (citing additional cases).

22. See Jordan v. United States Dep't of Justice, 691 F.2d 514, 516 n.14 (D.C. Cir. 1982) (attorney who receives fee award may ethically donate excess over nonprofit group's cost to nonprofit group, "just as he could donate monies obtained from other sources"). 
who did donate fee awards might hold back part of their fees to cover income taxes, ${ }^{23}$ and the tax laws would limit the percentage of their income they could claim as charitable deductions. ${ }^{24}$ In practical terms, then, the issue is whether public interest groups have or should have the right to raise money by sharing court-awarded legal fees.

Section I of this Article outlines the history and scope of the fee-sharing rule, as well as exceptions to it. This section concludes that fee-sharing agreements between lawyers and public interest groups technically violate the rules of legal ethics. Section II examines the effect of federal feeshifting statutes on the rule against fee sharing with nonlawyers, and concludes that neither the statute itself nor a judicial exception for groups with "separate litigation funds" definitively solves the problem. Section III asks whether the states ought to create an express exception to the feesharing rule so that lawyers may share fees with public interest organizations. I argue that the states should create such an exception, but I recognize that they may be unwilling to do so. Section IV asks whether the states have the constitutional power to prohibit lawyers from sharing court-awarded legal fees with public interest groups. I conclude that states probably do not have this power.

\section{History and Scope of the Rule Against Fee Sharing}

\section{A. History of the Rule Against Fee Sharing}

The rule against sharing legal fees with nonlawyers traces back to a 1729 English Act of Parliament ${ }^{25}$ that forbade an attorney to allow any nonattorney ${ }^{26}$ to use the attorney's name for profit. ${ }^{27}$ In the early 1800 's,

23. The IRS has ruled that an attorney appointed to defend an indigent must include fee awards in his gross income unless he is required by contract to turn over all fees to his employer or the legal aid society. See Rev. Rul. 65-282, 1965-2 C.B. 21.

24. See I.R.C. $\$ 170(b)(1)(A)$ (West 1987) (prohibiting individuals from deducting more than $50 \%$ of their adjusted gross income for charitable contributions). Thus, staff attorncys who voluntarily donate all fees to an organization would have to pay taxes on donated amounts in excess of $50 \%$ of their income. Consequently, staff attorneys would have a strong incentive to withhold at least enough fees to cover taxes on nondeductible donations.

25. Regulation of Attorneys and Solicitors Act, 2 Geo. 2, ch. 23 (1729). This omnibus act "For the better Regulation of Attorneys and Solicitors" set standards for fees, education, admissions, and several other facets of legal practice.

26. For general discussions of the history of the distinction between lawyers and nonlawyers, see Alexander, The History of the Law As an Independent Profession and the Present English System, in The Lawyer's Professional Independence: Present Threats/Future Challenges 1 (1984); Baker, Solicitors and the Law of Maintenance 1590-1640, 32 CAMBringe L.J. 56 (1973). Attorneys emerged as a distinct profession in England around 1250, and over several hundred years gained a monopoly on practice in the courts. See Alexander, supra, at 8-12. In the London courts, the demarcation between lawyers and nonlawyers sharpened in the sixteenth century, when a nonlawyer (then called a "homo laicus") was jailed for appearing in court. See id. at 10. But in many lower courts outside of London, nonlawyer "apprentices" were permitted to solicit cases and represent clients. See Baker, supra, at 57-60. The line between lawyers and nonlawyers grew brighter in the early 1700 's as Parliament clamped down on the growing problem of unauthorized practice.

27. 2 Geo, 2, ch. 23 , at $\S$ XVII (1729). A 1749 statute expanded and reinforced this prohibition. See Regulation of Attorneys and Solicitors Act, 22 Geo. 2, ch. 46, §§ II-XIX (1749). 
this language was the basis for the first case to strike down a fee-sharing arrangement between a lawyer and a nonlawyer. In Tench $v$. Roberts, ${ }^{28}$ an English court invalidated an attorney's agreement to pay his clerk onethird of the profits as a salary, because this in effect permitted a nonlawyer to use the attorney's name for profit. ${ }^{28}$

The United States Supreme Court first addressed fee sharing between lawyers and nonlawyers shortly after the Civil War. In Meguire v. Corwine, ${ }^{30}$ the plaintiff, a nonlawyer, had helped the defendant secure an appointment as special counsel for the government in the Farragut Prize Cases and had assisted the defendant in conducting the case. In exchange, the defendant had agreed to pay the plaintiff half of his fees. ${ }^{31}$ When a dispute arose, the Court said that fee-sharing agreements were "forbidden by a statute or condemned by public policy"32 and were "clearly illegal."33 Many later cases also chastised lawyers for paying nonlawyers a share of the fees to solicit clients. ${ }^{34}$

In 1908, the ABA adopted its influential Canons of Professional Ethics. $^{35}$ Canon 28 prohibited lawyers from paying nonlawyers to refer

28. 56 Eng. Rep. 1047 (1819).

29. The prohibition against sharing fees with a nonlawyer was not absolute, however. See Candler v. Candler, 37 Eng. Rep. 834, 836-37 (1821) (allowing widow to share in profits from her deceased husband's law practice). The Candler exception survives today in the Model Rules and Model Code, under which lawyers may direct a "firm, partner, or associate" to share fees with an estate or a specified person (such as a spouse) for a reasonable time after death. See MODEL RuLES, supra note 5, Rule 5.4(a)(1); MODEL CODE, supra note 5, DR 3-102(A)(1). Despite the age of the exception, its scope is still in flux. Compare O'Hara v. Ahlgren, Blumenfeld and Kempster, No. 65,760 (IIl. Mar. 29, 1989) (WESTLAW, IL-CS database) (fee-sharing rule prohibits lawyers taking over sole practitioner's practice from sharing legal fees with sole practitioner's widow) with Chicago Bar Ass'n Comm. on Professional Responsibility, Op. 85-1 (Oct. 1985) (lawyer taking over clients from deceased sole practitioner may split fees with estate if clients consent), summary printed in [Ethics Opinions] Law. Man. on Prof. Conduct (ABA/BNA) 801:3204 (1986).

30. 101 U.S. 108 (1879).

31. Id. at 108 .

32. Id. at 111 .

33. Id. at 112 .

34. In Alpers v. Hunt, 86 Cal. 78, 87-90, 24 P. 846, 849-50 (1890), for example, two lawyers promised to pay a nonlawyer one-third of their fee if the nonlawyer convinced a wealthy woman to retain the lawyers. The court declared the agreement void. Accord Langdon v. Conlin, $67 \mathrm{Neb}$. 243, 247,93 N.W. 389,390 (1903) (fee-sharing agreement was just "a thinly veiled subterfuge" for nonlawyer to violate state's unauthorized practice laws, which protected clients from "shysters, charlatans and mountebanks"). A more recent example is In re Frankel, 20 N.J. 588, 120 A.2d 603 (1956), in which a lawyer had paid $25 \%$ of his legal fees to a nonlawyer for referring auto accident cases to the lawyer. The court suspended the lawyer for two years, but Justice Brennan (then on the New Jersey Supreme Court) thought suspension was too light and would have voted for disbarment. 20 N.J. at 599, $120 \mathrm{~A} .2 \mathrm{~d}$ at 609 (Brennan, J., dissenting).

In contrast, lawyers themselves were generally allowed to solicit cases in person through the early 1900 's. See Chreste v. Louisville Ry. Co., 167 Ky. 75, 84, 180 S.W. 49, 53 (1915) (since only one case up to that time had voided solicited contract, court held that "mere solicitation on the part of an attorney, unaccompanied by fraud, misrepresentation, undue influence, or imposition of some kind" would not void contract between attorney and client).

35. Earlier codes of ethics did not mention fee sharing between lawyers and nonlawyers. The earliest codes of ethics in America were essays by legal writers and lecturers, which were not binding in any jurisdiction. See, e.g., 2 D. Hoffman, A Course of LEGAL STudy 752-75 (2d ed. 1836); G. Sharswood, An Essay on Professional Ethics (5th ed. 1896) (originally published in 1854 as A Compend of Lectures on the Aims and Duties of the Profession of the LaW, delivered 
cases, ${ }^{36}$ but the Canons did not otherwise prohibit fee sharing with nonlawyers. This omission left open the possibility that lawyers could share fees for such purposes as compensating employees or paying for legitimate services.

Courts and legislatures soon closed this gap. ${ }^{37}$ In response to the emergence of giant corporations that began offering legal services at the turn of the century, including one law corporation that employed an astonishing six thousand lawyers nationwide, ${ }^{38}$ many states passed laws prohibiting corporations from practicing law. ${ }^{39}$ The laws against corporate practice

before the Law Class of the University of Pennsylvania). The first formally binding code was the Alabama Code of 1887. See Armstrong, A Century of Legal Ethics, 64 A.B.A. J. 1063, 1063-64 (1978).

36. Canon 28 said it was "disreputable" for a lawyer "to pay or reward, directly or indirectly, those who bring or influence the bringing of such cases to his office." Canons of Professional ETHICs Canon 28 (1908). This prohibition was an old one and had been enforced for many years by state criminal statutes, whether the nonlawyer received a salary, a flat fee, or a share of the fees for referring cases. See In re Clark, 108 A.D. 150, 158-67, 95 N.Y.S. 388, 394-99 (1905) (attorney who violated state law by paying nonlawyer three to five dollars per case to refer more than 2000 claims was disbarred for running "litigation hunting agency"), aff'd, 184 N.Y. 222, 77 N.E. 1 (1906); Allen v. Hawks, 30 Mass. (13 Pick.) 79, 83 (1832) (construing state statute that prescribed penalty for any person who promised "any valuable consideration" to procure note with intent to profit from legal fees arising from collection suit on note).

37. Many states had already attacked fee sharing through statutes prohibiting the unauthorized practice of law. See generally Rhode, Policing the Professional Monopoly: A Constitutional and Empirical Analysis of Unauthorized Practice Prohibitions, 34 Stan. L. Rev. 1, 6-8 (1981) (collecting statutes and cases). Unauthorized practice statutes did not mention fee sharing per se, but a nonlawyer's receipt of legal fees was sometimes cited as evidence that the nonlawyer was illegally practicing law. See, e.g., Alpers v. Hunt, 86 Cal. 78, 88, 24 P. 846, 849 (1890); Candler v. Candler, 37 Eng. Rep. 834, 836 (1821) (widow had not acted as attorney, "but the point contended for . . would be, that her taking the profits would be evidence that she had done so").

38. This was the Associated Lawyers' Company, a corporation partially owned by nonlawyers. See In re Associated Lawyers' Co., 134 A.D. 350, 351, 119 N.Y.S. 77, 77-78 (1909). The company's initial capitalization was an impressive $\$ 125,000$, and all but five stockholders were lawyers. The company's main business was collecting claims without filing suit, a field open to nonlawyers, but when a lawsuit was necessary to collect a claim, the company used lawyers in its employ. See 134 A.D. at 351, 119 N.Y.S. at 77-78. Companies like Associated Lawyers had many advantages for clients. They offered one-stop shopping for collection work and litigation, and quality was paired with convenience because they employed and monitored lawyers familiar with collection work in all parts of America. This saved clients the trouble of locating competent collection lawyers out of town, and the "brand names" of the giant law corporations gave them a strong incentive to ensure quality so that clients would return with more business.

Another pioneer law corporation was the Co-operative Law Company. Through its legal staff, Cooperative transacted "a general law business, including the prosecution and defense of suits; incorporation of business enterprises; drawing of contracts, leases and agreements, drawing and probating of wills, management of estates, etc." In re Co-operative Law Co., 198 N.Y. 479, 481, 92 N.E. 15, 15 (1910). The board of directors selected and supervised all staff attorneys and set their fees. See id.

The lives of Associated and Co-operative were glorious but short. After New York passed a statute forbidding corporations from practicing law, neither corporation was able to renew its corporate charter. See Co-operative Law, 198 N.Y. at 482-84, 92 N.E. at 16; Associated Lawyers, 134 A.D. at 352-53, 119 N.Y.S. at 78-79. According to Associated Lawyers, such organizations had never properly offered a legal practice. 134 A.D. at 352, 119 N.Y.S. at 78 ("[I]t has never been legal for a corporation to practice law.").

39. See, e.g., Mass. Gen. L. ch. 292, §§ 1-3 (1916); 1917 R.I. Acts \& Resolves ch. 1494, § 2. New York's statute, which was typical, prohibited corporations from practicing law, rendering legal services, giving legal advice, furnishing attorneys to provide legal services, or advertising or soliciting legal business. See N.Y. Penal Law $\$ 280$ (Consol. 1909); N.Y. Bus. Corp. Law $\S 2$-a (Consol. 1909). 
stopped corporations from employing salaried lawyers to provide legal services to third parties and turn over the fees to the corporation. The ban on corporate law practice thus cut off one avenue through which nonlawyers might have shared fees.

The hostility to the corporate practice of law was explained in In re Co-operative Law Company: ${ }^{40}$

The relation of attorney and client . . . cannot exist between an attorney employed by a corporation to practice law for it, and a client of the corporation, for he would be subject to the directions of the corporation and not to the directions of the client ... . The corporation would control the litigation, the money earned would belong to the corporation and the attorney would be responsible to the corporation only. ${ }^{41}$

New York was not alone in condemning the practice of law by corporations. By 1935, nearly half the states had passed laws prohibiting corporations from furnishing lawyers for profit. ${ }^{22}$

In 1925 , the ABA ruled that lawyers were also ethically forbidden to share fees with nonprofit organizations. A local bar asked whether attorneys could accept employment with an auto club to serve club members. ${ }^{43}$ The attorneys were salaried and did not charge members for legal services. Although the Canons of Professional Ethics did not yet prohibit fee sharing with nonlawyers, the ABA relied on Co-operative Law and similar holdings against the "practice of law" by corporations, denouncing the relationship as "a division of professional fees with a lay agency"44 whether or not the club was organized for profit. ${ }^{48}$

In 1928, the ABA formalized its opposition to fee sharing by adopting Canon 34, which directly prohibited fee sharing with nonlawyers. It provided that "[n]o division of fees for legal services is proper, except with

40. 198 N.Y. 479, 92 N.E. 15 (1910). A lower court had originally found that Co-operative was "lawfully engaged" in business and had granted approval, but the chairman of the Brooklyn Bar Association's grievance committee soon moved to vacate the order of approval. After a hearing, the court vacated its prior approval. The New York Court of Appeals affirmed.

41. 198 N.Y. at 483-84, 92 N.E. at 16 (emphasis added).

42. See Wormser, Corporations and the Practice of Law, 5 Fordham L. Rev. 207, 207, 218 (1936) (citing statutes and arguing that "to exclude corporations entirely from the practice of the law is idle, impractical, and adopts a too narrow view of the important business and social considerations").

43. See ABA Comm. on Ethics and Professional Responsibility, Formal Op. 8 (1925), reprinted in American Bar association, Opinions of the Committee on Professional Ethics and GRIEVANCES 71 (1957).

44. Id. at 75 (emphasis added).

45. Id. at 74. The organization's members did not receive any direct monetary benefit from the legal services, but the $A B A$ said that "the club as an entity may profit from this particular activity to the benefit of its other activities and the membership thereby receive an indirect benefit or profit." Id. The opinion intentionally did not state whether the auto club itself was organized for profit, because the Committee believed that the club's plan was forbidden under the Canons "[e]ven if the club is not organized for profit." Id. 
another lawyer, based upon a division of service or responsibility."'46 This prohibition was designed to halt law practice by large banks that could "grab off all the legal business in the community,"47 and was probably also aimed at ambulance chasers whose abusive practices were publicized during extensive hearings and investigations in both $\mathrm{New}$ York ${ }^{48}$ and Philadelphia $^{48}$ in 1928.

The bar's intolerance for fee sharing with nonlawyers has not changed since the adoption of Canon 34. Curiously, however, courts virtually ignored Canon 34 in connection with nonprofit organizations. ${ }^{50}$ The courts continued to condemn fee sharing, but seldom cited Ganon 34. Instead, they relied on the older Canon 28, which forbade the payment of any compensation for securing cases, ${ }^{51}$ and on a new Canon 35, adopted by the $\mathrm{ABA}$ at the same time as Canon 34, which prohibited lawyers em-

46. Canons of Professional Exhics Canon 34 (1928). Another new canon, Canon 35, reinforced the fee-sharing prohibition by providing that a lawyer employed by an association, club, or other organization could not "render legal services . . . to the members of such an organization in respect to their individual affairs." Id. Canon 35. One purpose of Canon 35 was to stifle the "commercialization of the practice of law" that was thought to occur when lawyers working for nonprofit groups advertised that they provided legal services. See 51 REPORTS A.B.A. 82-83 (1926) (report of Committee on Professional Ethics and Grievances).

Neither Canon 34 nor Canon 35 provided an exception for nonprofit organizations. An angry minority report therefore opposed Canon 35, arguing that it would "condemn many organizations which meet, in a perfectly legitimate and convenient manner, a need of the public." 52 REPORTS A.B.A. 390 (1927).

47. See 51 REPorts A.B.A. 82-83 (1926) (report of Committee on Professional Ethics and Grievances). The leading application of the new canons to a bank was People v. People's Stock Yards State Bank, 344 Ill. 462, 176 N.E. 901 (1931). For several years, the bank's lawyers had helped the bank's customers with wills, real estate transactions, and foreclosures. The bank's lawyers charged their regular fees and turned them all over to the bank, so the bank turned a handsome profit. The Illinois court enjoined the practice, held the bank in contempt of court, and fined it $\$ 1000$. 344 Ill. at 479-80, 176 N.E. at $908-09$.

48. See People ex rel. Karlin v. Culkin, 248 N.Y. 465, 162 N.E. 487 (1928). Justice Cardozo wrote: "Ambulance chasing' was spreading to a demoralizing extent. . . . Retainers, often on extravagant terms, were solicited and paid for. Calendars became congested through litigations maintained without probable cause as weapons of extortion." 248 N.Y. at 468,162 N.E. at 488.

49. See Report of the Committee of Censors to the Law Assaciation of Philadelphia: In re Contingent Fee Accident Litigation, reprinted in 14 MAss. L.Q. 1 (Supp. 1928) [hereinafter Philadelphia Report]. The Philadelphia story was a sordid tale about personal injury lawyers paying vast networks of runners, police officers, ambulance drivers, doctors, nurses, hospital switchboard operators, and others to locate or solicit personal injury suits. Sharing contingent fees was one of the main currencies for purchasing claims. Id. at 14-15. To combat the abuses, the Philadelphia Bar recommended adoption and strict enforcement of a flat prohibition on fee sharing. Id. at 22 (recommending that "no attorney shall, directly or indirectly, divide his fee with" nonlawyer).

50. Both the courts and the bar, however, remained vigilant about invoking Canon 34 against fee sharing with nonlawyers for profit. See, e.g., Application of Guberman, 90 Ariz. 27, 363 P.2d 617 (1961) (en banc) (fee splitting with person not admitted to practice law is clearly violation of Canon 34 and tends to show lack of moral character); In re Introcaso, 26 N.J. 353, 140 A.2d 70 (1958) (attorney violated Canon 34 by dividing fees with nonlawyer runner who solicited cases); AMERICAN Bar Association, Opinions of the Commttee on Professional Ethics 150-52 (1967) (summarizing more than one dozen ABA opinions under Canon 34 between 1928 and 1967).

51. See In re O'Neill, 5 F. Supp. 465 (E.D.N.Y. 1933) (without mentioning Canon 34, court censured lawyer under Canons 28 and 35 for having clients agree to pay part of recovery to lawyer and part to trainmen's union); In re Petition of Comm. on Rule 28, 29 Ohio N.P. (n.s.) 291, 298-303 (1932) (without mentioning Canon 34, court found that fee splitting arrangement between lawyer and legal department of trainmen's union violated Canons 27, 28, and 35); supra text accompanying note 36 (quoting Canon 28). 
ployed by "intermediaries" (including nonprofit groups) from rendering legal services for third parties. ${ }^{52}$ In the early 1930's, the bar launched a nationwide "war" against the unauthorized practice of law, ${ }^{5 s}$ and the receipt of any share of legal fees (or even the mere hiring of a staff attorney) was considered proof that a nonprofit group was "practicing law."54

The bar's crusade against unauthorized practice continued throughout the 1950's and into the 1960's. ${ }^{65}$ During the 1960's and 1970's, however, the Supreme Court decided a series of cases that gave nonprofit groups the First Amendment right to solicit and finance cases, refer matters to specific lawyers, and hire staff attorneys. ${ }^{56}$ These cases virtually erased the canon concerning intermediaries, and they sharply limited state power to prosecute nonprofit groups for the unauthorized practice of law. ${ }^{57}$ One of these cases, In re Primus, ${ }^{88}$ suggests that the Court might strike down the blanket prohibition on fee sharing between lawyers and public interest organizations if the issue were squarely presented..$^{59}$ But neither Primus nor any other Supreme Court case has definitely approved fee sharing with public interest groups, ${ }^{80}$ and the Court has twice declined opportuni-

52. See 53 RePorts A.B.A. 120-30 (1928) (debate in ABA House of Delegates over new canons, including Canons 34 and 35, culminating in their adoption); supra notes 46 (discussing Canon 35, which restricted use of "intermediaries") \& 51 (citing cases).

53. See Rhode, supra note 37, at 3, 6-11 (recounting history of bar's unauthorized practice campaign).

54. See, e.g., Illinois State Bar Ass'n v. United Mine Workers, 35 Ill. 2d 112, 117, 219 N.E.2d 503, 506 (1966) ("[O]rganizations, including not-for-profit organizations, which hire or retain lawyers to represent their individual members in legal matters are ordinarily engaging in the unauthorized practice of law."), rev'd, 389 U.S. 217, 221-22 (1967) (holding that unions have constitutional right to hire attorneys to assist individual members); Rhode Island Bar Ass'n v. Automobile Serv. Ass'n, 55 R.I. 122, 179 A. 139 (1935) (voluntary association's collection of dues to finance various legal services without further charge to members constituted unauthorized practice of law).

55. See Rhode, supra note 37, at 8-9 (discussing bar's activities between 1930 and 1960).

56. See In re Primus, 436 U.S. 412 (1978) (lawyer may solicit cases for civil rights group that may benefit financially from fee award); United Transp. Union v. State Bar, 401 U.S. 576 (1971) (labor union may recommend specific attorneys to its members and limit their fees); United Mine Workers v. Illinois State Bar Ass'n, 389 U.S. 217 (1967) (holding that labor union has First Amendment right to hire attorneys to serve its members in their individual cases); Brotherhood of R.R. Trainmen v. Virginia ex rel. Virginia State Bar, 377 U.S. 1 (1964) (labor union has right to recommend specific attorneys to its injured members); NAACP v. Button, 371 U.S. 415 (1963) (civil rights group has First Amendment right to recommend and pay specific attorneys to bring school desegregation suits on behalf of member and nonmember plaintiffs). For detailed discussions of these cases, see infra text accompanying notes 270-316.

57. In United Mine Workers, the Supreme Court overturned a state court holding that hiring an attorney to serve union members constituted an unauthorized practice of law. See 389 U.S. at 221-25. The Button case expressly rejected a state court holding that the NAACP's activities violated Canon 35 (governing intermediaries) and Canon 47 (barring lawyers from assisting unauthorized practice of law). See 371 U.S. at 424-26 \& n.8 (quoting Canons 35 \& 47).

58. 436 U.S. 412 (1978).

59. The general principles articulated in Primus suggest that the Court would recognize a First Amendment right of attorneys to share fees with public interest groups if the issue were squarely presented, but Primus itself did not discuss the fee-sharing rule, and thus left open the precise issues addressed in this Article. See infra text accompanying notes 305-11 (distinguishing Primus).

60. See infra text accompanying notes $300-11$. 
ties to approve fee-sharing arrangements between lawyers and labor unions. $^{6 \mathrm{x}}$

When the ABA adopted the Model Code of Professional Responsibility in 1969,22 Disciplinary Rule 3-102(A) provided: "A lawyer or law firm shall not share fees with a nonlawyer." ${ }^{\text {B }}$ But not everyone shared the bar's views. The Kutak Commission, a special commission appointed in 1976 to recommend revisions to the 1969 Code, suggested that the feesharing rule be substantially relaxed. Specifically, the Kutak Commission proposed that lawyers be allowed to share fees with nonlawyers, even in profit-making enterprises, if the nonlawyers agreed not to influence the attorneys' independent professional judgment and to abide by the rules of legal ethics regarding confidentiality, solicitation, and legal fees. ${ }^{64}$

The Commission's proposal to allow fee sharing attracted little controversy or comment for several years. ${ }^{65}$ But when the ABA House of Delegates debated a final draft of the Model Rules, a delegate asked the Commission's Reporter whether the proposed rule would "permit a business corporation such as Sears Roebuck or $H \& R$ Block to open law offices staffed by salaried lawyers in shopping centers across the country." ${ }^{\text {"B }}$ "The Reporter said that it would. ${ }^{87}$ The debate that followed was intense and

61. See infra text accompanying notes 300-04.

62. Effective January 1, 1970, the Model Code of Professional Responsibility replaced the ABA's Canons of Professional Ethics. See American Bar Foundation, Annotated Code of ProfesSIONAL RESPONSIBILITY xi (1979) (explaining legislative history of Code).

63. MODEL CODE, supra note 5, DR 3-102(A). Three narrow exceptions involved deceased lawyers, retired lawyers, and retirement plans for law firm employees. Id. Only the retirement plan exception has any conceivable relevance for the purposes of this Article. See infra text accompanying notes 88-89 (discussing exception for compensation and retirement plans).

64. The Kutak Commission's Proposed Final Draft of Rule 5.4, which was expressly intended to replace the rule against fee sharing with nonlawyers (and several other rules that excluded nonlawyers from the legal business), provided:

A lawyer may be employed by an organization in which a financial interest is held or managerial authority is exercised by a nonlawyer ... such as a business corporation, insurance company, legal services organization or government agency, but only if:

(a) there is no interference with the lawyer's independence of professional judgment or with the client-lawyer relationship;

(b) information relating to representation of a client is protected as required by Rule 1.6;

(c) the organization does not engage in advertising or personal contact with prospective cli-

ents if a lawyer employed by the organization would be prohibited from doing so by Rule 7.2 or 7.3 ; and

(d) the arrangement does not result in charging a fee that violates Rule 1.5.

American Bar Association Genter for Professional Responsibility, The legislative History of the Model Rules of Professional Conduct: Their Development in the ABA House of Delegates 159-60 (1987) (emphasis added). By holding a financial interest in an organization, nonlawyers could have shared in legal fees. In any event, the basic prohibition against fee sharing would have been completely eliminated.

65. G. Hazard \& W. Hodes, The Law of Lawyering: a Handbook on the Model Rules of Professional. Conduct 469 (1986) [hereinafter Hazard \& Hodes, The Law of LAWYERING].

66. Transcript of floor debate by ABA House of Delegates, HOD Tape 10, at 28 (Feb. 8, 1983) [hereinafter Transcript] (question of Robert Hawkins, former President of Missouri Bar).

67. Id. at 29. The Kutak Commission's Reporter was Professor Geoffrey Hazard, Jr. of the Yale Law School. 
impassioned. $^{68}$ In the end, the proposal to allow fee sharing with nonlawyers became "the only proposed Rule to suffer total rejection" in the House of Delegates. ${ }^{69}$ In its place, the $\mathrm{ABA}$ adopted an amendment ${ }^{70}$ that continued the existing ban on fee sharing verbatim. ${ }^{71}$ The net result is that every state now prohibits fee sharing with nonlawyers.

\section{B. Scope of the Rule Against Fee Sharing}

Nearly all public interest organizations require staff attorneys to turn over all court-awarded fees, and many public interest organizations require cooperating attorneys to turn over all or part of their fees. ${ }^{72}$ Do these agreements violate the rule against fee sharing with nonlawyers?

The fee-sharing rule has two sweeping components. The first, which applies to both staff and cooperating attorneys, is that lawyers may not share fees with nonlawyers who perform services for them-they may not pay nonlawyers a share of the fees rather than a fixed salary or wage. The most common example of this prohibition is that lawyers may not share fees with nonlawyers as payment for soliciting and referring cases. ${ }^{73}$

68. See, e.g., id. at 33 (delegate noting that "there is one California law firm widely advertised, with offices in many states, perhaps some of yours, that intends to go public if this House should adopt Rule 5.4"); id. at 36 (delegate decried proposal as "demeaning to the profession"); id. at 37-39 (speech by delegate from General Practice Section in favor of that Section's amendment maintaining status quo); id. at 42 (delegate asked: "[W]ho is in trouble if there is a violation of these [proposed] rules? Is it the [lay] venturer or the lawyer? It's the lawyer; the venturer isn't even under the jurisdiction.").

69. Hazard \& Hodes, The Law of Lawyering, supra note 65, at 469.

70. The amendment was proposed by the General Practice Section. See Transcript, supra note 66, at 37. The membership of the General Practice Section consists primarily of lawyers in relatively small firms, which would be greatly threatened by the expansion of firms such as Hyatt Legal Services and Jacoby \& Meyers.

71. Compare Model Rules, supra note 5, Rule 5.4(a) with MOder CoDE, supra note 5, DR 3102(A). One delegate damned the status quo as "the cave man and woman mentality." Transcript, supra note 66 , at 43 . But another delegate praised it, saying, "I think we should live with what we have because it's been good enough in the past." Id. at 44 .

The Kutak Commission's proposals were briefly resurrected in 1986, when both the North Dakota and District of Columbia bars proposed versions of Rule 5.4 very much like the defeated Kutak proposal. See Kaplan, Want to Invest in a Law Firm?, Nat'l L.J., Jan. 19, 1987, at 1, col. 4. The North Dakota Supreme Court, however, rejected its bar's proposal, instead adopting Model Rule 5.4. See [2 Current Reports] Law. Man. on Prof. Conduct (ABA/BNA) No. 23, at 462 (Dec. 10, 1986). The D.C. Bar's proposal is still pending, see Glaser, Court Set to Act on Bar's Ethics Proposal, Legal Times, June 27, 1988, at 20, col. 1 (noting that D.C. Court of Appeals has been deliberating on proposals since 1986), but the D.C. Bar has substantially trimmed back its original proposal (which mirrored the Kutak Commission's language). The current proposal would allow fee sharing only with nonlawyers who perform professional services that assist an organization in rendering legal services to clients. See Gilbert \& Lempert, The Nonlawyer Partner: Modest Proposals Deserve A Chance, 2 Geo. J. Legal Ethics 383, 398-400 (1988) (explaining D.C. Bar's retrenchment from its original proposal).

72. See supra text accompanying note 18.

73. See, e.g., In re Pyle, 363 N.W.2d 303, 304 (Minn. 1985) (lawyer disciplined for paying fees to nonlawyer employees of firm for referring cases to firm); In re Lebowitz, 67 A.D.2d 240, 241, 414 N.Y.S.2d 735, 736 (1979) (lawyer disciplined for sharing legal fees with nonlawyer as inducement to refer criminal cases to firm); In re Bregg, 61 N.J. 476, 477, 295 A.2d 360, 361 (1972) (lawyer suspended for paying share of fees to nonlawyer to refer cases). For more examples, see supra text accompanying notes 30-34. For a discussion of possible exceptions for public interest groups, see infra 
Conceptually, one could say that staff attorneys and cooperating attorneys are sharing fees with public interest organizations to pay the groups for soliciting and referring cases, which violates the literal language of Rule $5.4(\mathrm{a}) .^{74}$

The second component of the fee-sharing rule, which applies only to staff attorneys, is that lawyers may not share fees with nonlawyers who employ them-they may not give nonlawyers a share of the fees in exchange for a fixed salary. Thus, lawyers on salary from a corporation may not allow the corporation to charge third parties for the lawyers' services ${ }^{75}$ nor may the lawyers collect fees and remit them to the corporation. ${ }^{76}$ Some jurisdictions have ruled that a company's in-house counsel may not remit fees to the company even if the lawyer won the fees while representing the employer. ${ }^{77}$ By analogy, staff attorneys would appear to be violating the fee-sharing rule by turning over all fees to the public interest organizations that employ them.

The breadth of the rule against fee sharing is matched by the strictness with which it is construed. For example, a lawyer cannot circumvent the rule by having a client pay part of the fees directly to a nonlawyer. The courts will look beyond the technical terms of the contract to hold that the

text accompanying notes 90-110 (discussing lawyer referral services).

74. For a discussion of express and implied exceptions to this literal construction of the feesharing rule, see infra text accompanying notes 88-110.

75. See, e.g., Massachusetts Bar Ass'n Comm. on Professional Ethics, Op. 84-1 (May 18, 1984), reprinted in [1984-1 Transfer Binder] Nat'l Rep. on Legal Ethics \& Prof. Resp. (UPA) MA:OPINIONS:4 (it would be "unethical fee-splitting" for bank to bill staff attorney's time to customers at more than bank's actual cost for staff attorney's services); Tennessee Supreme Court Comm. on Ethics, Formal Ops. 83-F-44 \& 83-F-44(a) (Apr. 14, 1983) (corporate counsel may not permit corporation to collect for legal services performed by lawyer), summary printed in [Ethics Opinions] Law. Man. on Prof. Conduct (ABA/BNA) 801:8108 (1985). In recent years, some states have adopted an exception that allows lawyers to share legal fees with nonlawyers as part of a compensation plan. For a discussion of this exception, see infra text accompanying notes 88-89.

76. See, e.g., Arizona State Bar Comm. on Rules of Professional Conduct, Op. 82-18 (Dec. 1, 1982), summary printed in [Ethics Opinions] Law. Man. on Prof. Conduct (ABA/BNA) 801:1315 (1984) (lawyer cannot accept employment with corporation to provide paralegal and legal services to attorneys); Michigan State Bar Comm. on Professional and Judicial Ethics, Op. CI-917 (Apr. 26, 1983), summary printed in [Ethics Opinions] Law. Man. on Prof. Conduct (ABA/BNA) 801:4864 (1984) (attorney may not open office in which nonlawyer guarantees lawyer's salary since salary arrangement would result in improper fee sharing with nonlawyer); Dallas Bar Ass'n Comm. on Legal Ethics, Op. 1982-3 (July 9, 1982), summary printed in [Ethics Opinions] Law. Man. on Prof. Conduct (ABA/BNA) 801:8405 (1985) (attorney is considered to be sharing legal fees with nonlawyer if employing corporation reaps any benefit, reward, or profit from attorney's provision of legal services to third parties).

77. See, e.g., PPG Indus., Inc. v. Celanese Polymer Specialties Co., 840 F.2d 1565, 1570 (Fed. Cir. 1988) (when calculating statutory fee awards to corporation based on services of in-house counsel, courts should base award on corporation's cost plus overhead in connection with in-house counsel's services, rather than market rate for comparable attorneys in private practice, because "implication of using a private firm market standard is to allow a nonlegal business corporation to use the services of in-house counsel, and to reap a profit therefrom"); People v. People's Stock Yards State Bank, 344 Ill. 462, 477, 176 N.E. 901, 908 (1931) (condemning bank's practice of retaining courtawarded attorney fees based on work done by its legal department in foreclosure suits on loans owned by bank); Missouri Bar Admin., Formal Op. 43, reprinted in $20 \mathrm{~J}$. Mo. BAR 33 (1964) (salaried attorney employed by corporation who sues to collect on note owned by corporation may not request attorney fees if fees will be turned over to corporation). 
lawyer is unethically sharing fees. ${ }^{78}$ Moreover, although clients can waive numerous other ethical rules ${ }^{78}$ they cannot waive the prohibition against sharing fees with nonlawyers. ${ }^{80}$ Finally-and of cardinal importance here-Rule 5.4(a) contains no express exception for nonprofit groups. ${ }^{81}$ This is significant because another subsection of the same rule-Rule 5.4(d) -is specifically limited to organizations practicing law "for a profit." ${ }^{\text {"22 }}$ The absence of any parallel limitation in Rule 5.4(a) is consistent with the historical practice of applying the prohibition against fee sharing to profit and nonprofit organizations alike.

All of these factors-broad range, strict construction, unwaivability, and lack of any express exception for nonprofit organizations-indicate that the prohibition against sharing fees with nonlawyers applies to lawyers working with public interest organizations. If this is true, then staff and cooperating attorneys cannot agree to share court-awarded fees with public interest organizations unless the rule contains an exception.

\section{G. Exceptions to the Rule}

\section{Are Public Interest Groups "Law Firms"?}

The simplest solution to the fee-sharing problem would be to define the problem away by calling public interest groups "law firms." Unfortunately, this will not help any organization that does not employ staff attorneys or that is unwilling to relinquish complete control over all fees to the staff attorneys. The Model Rules define "firm" or "law firm" to be "a lawyer or lawyers in a private firm, lawyers employed in the legal department of a corporation or other organization and lawyers employed in a legal services organization."83 For organizations that rely solely on coop-

78. See, e.g., In re O'Neill, 5 F. Supp. 465, 467 (E.D.N.Y. 1933) ("no difference in principle" between contract obligating lawyer to pay one-fourth of $20 \%$ fee to union and contract requiring client to pay $15 \%$ to lawyer and 5\% directly to union); Committee on Professional Ethics and Conduct v. Lawler, 342 N.W.2d 486, 488 (Iowa 1984) (fee agreement between client and lawyer providing for direct hourly rate payments to paralegal for services rendered by paralegal amounted to improper division of fees between lawyer and paralegal); In re Petition of Comm. on Rule 28, 29 Ohio N.P. (n.s.) 291, 303 (1932) (finding no difference between contract obligating lawyer to pay one-fourth of $20 \%$ fee to union and contract requiring client to pay $15 \%$ to lawyer and $5 \%$ directly to union).

79. See, e.g., Model Rules, supra note 5, Rule 1.2(c) (lawyer may limit objectives of representation "if the client consents after consultation"); id. Rule 1.5(e) (lawyer may divide fees with another lawyer not in same firm "by written agreement with the client"); id. Rule 1.7(a) (lawyer may represent client whose interests are directly adverse to another client if "each client consents after consultation"); id. Rule 1.8(a) (lawyer may acquire pecuniary interest adverse to client if "the client consents in writing thereto").

80. See Gillers, What We Talked About When We Talked About Ethics: A Critical View of the Model Rules, 46 OHIO ST. L.J. 243, 272 (1985) ("Rule 5.4 envisions no opportunity for client consent.").

81. See MODEL Rules, supra note 5, Rule 5.4(a).

82. Id. Rule 5.4(d) (prohibiting lawyer from practicing "with or in the form of a professional corporation or association authorized to practice law for a profit" if nonlawyer owns any interest, is officer or director, or "has the right to direct or control the professional judgment of a lawyer").

83. Id. terminology section (preceding Rule 1.1) (emphasis added). The Model Code is more restrictive; it defines "law firm" to include "a professional legal corporation," which is separately 
erating attorneys and do not employ any staff attorneys, this definition offers no consolation. ${ }^{84}$

Even for organizations that do employ staff attorneys, the definition in the Rules poses difficulties. Since only the lawyers in the organization constitute a law firm, any legal fees that accrue based on their work cannot be shared with anyone except other lawyers in the organization. ${ }^{85}$ In other words, all legal fees must either be distributed to the lawyers personally or placed in a segregated account controlled by lawyers. ${ }^{88}$ This requirement of exclusive lawyer control over all legal fees is likely to cause a problem for many public interest groups. Staff attorneys are by definition employees of the organization, and the nonlawyer officers or directors of the organization may not be willing to give staff attorneys complete control over such significant sums of money. If the nonlawyers are willing to give up control over the money, then the definitional solution may work. The staff attorneys will be sharing fees only within the "law firm," so there will be no fee sharing with nonlawyers. But if the nonlawyers in the organization desire control over the disposition of the fees, the definitional solution will not work. Once the staff attorneys assume control over the fees, the organization will lose the right to insist that the fees be applied to the organization's general purposes. The attorneys may use the money for virtually any purpose they wish ${ }^{87}$-including

defined as "a corporation . . . authorized by law to practice law for profit." Model Code, supra note 5, definitions section (following DR 9-102). The Code also defines a "qualified legal assistance organization" as "an office or organization of one of the four types listed in DR 2-103(D)(1)-(4), inclusive that meets all the requirements thereof." Id. (footnote omitted). One of the requirements of DR $2-103(D)(1)-(4)$ is that the organization "is so organized and operated that no profit is derived by it from the rendition of legal services by lawyers." Id. DR 2-103(D)(4)(a). Since public interest groups are not authorized to practice law for a profit, they cannot qualify as a "law firm" under the Code. Yet since they derive a "profit" by sharing in market rate legal fees, they also do not meet the definition of a qualified legal assistance organization. Thus, the Code does not provide any definitional solution to the problem.

84. In my empirical survey, I found that approximately $50 \%$ of all ACLU affiliates and $15 \%$ of other public interest groups do not employ any staff attorneys. These groups depend entirely on cooperating attorneys for their legal work.

85. The rules place no restrictions on sharing fees with other lawyers in the same firm. See MODEl Rules, supra note 5, Rule 1.5(e) ("[a] division of a fee between lawyers who are not in the same firm may be made only if" division of fees satisfies certain criteria; but rule makes no mention of sharing fees among lawyers in same firm (emphasis added)). Of course, fees may be shared with nonlawyers if the fee-sharing plan fits within one of the exceptions discussed in Sections I-C and II-B.

86. A separate account controlled by the lawyers parallels the usual arrangement in private law firms, where all fees are typically deposited in an account used by the law firm to cover lawyer employment costs, nonlawyer employment costs, and a variety of other operating expenses. See M. Altman \& R. Weil, How to Manage Your Law Office § 11.10 (1988) (describing typical law firm system of accounts).

87. The rules of legal ethics place only a few restrictions on the ways in which lawyers may agree to use their fees. The rules restrict the rights of lawyers to acquire business interests adverse to a client, provide financial assistance to a client in connection with pending litigation, offer an unlawful inducement to a witness for testimony, pay for recommendations or referrals, share fees with nonlawyers or with lawyers not in the same firm, or use fees for purposes that are criminal, dishonest, fraudulent, deceitful, or prejudicial to the administration of justice. See MODEL RuLEs, supra note 5, Rules 1.5(e), 1.8(a) \& (e), 3.4(b), 5.4(a), 8.4(b)-(d). Beyond that, the rules of legal ethics do not specifically address or limit the uses to which lawyers may put their fees. Lawyers may thus agree to 
the organization's nonlitigation program-but the lawyers must be in sole control of the funds. Since this may pose a problem for many organizations, we must see whether the rules provide some other exception.

\section{Compensation Plans for Nonlawyer Employees}

The fee-sharing rule has only one express exception worth discussing. Rule 5.4(a)(3) provides that "a lawyer or law firm may include nonlawyer employees in a compensation or retirement plan, even though the plan is based in whole or in part on a profit-sharing arrangement." ${ }^{88}$ Under this provision, lawyers may apparently agree to base the compensation of their employees on the amount of fees the lawyers earn. But this exception is unhelpful to public interest organizations because nonlawyers ordinarily are not "employees" of the lawyers. Cooperating attorneys are similar to independent contractors, and they do not employ the nonlawyers at public interest organizations. Staff attorneys are typically employees, not employers.

To take advantage of the compensation plan exception, many public interest organizations would have to restructure their operations so that staff attorneys would become the employers of all nonlawyers. This is probably impractical and would in any event be irrelevant with respect to cooperating attorneys. Perhaps sophisticated contracts could divert some fee awards to nonlawyers under the compensation plan exception, but this does not represent a simple or global solution to the problem. ${ }^{89}$

\section{Referral Fees}

Another possible avenue around the fee-sharing rule is ABA Model Rule 7.2(c), which states: "A lawyer shall not give anything of value to a person for recommending the lawyer's services, except that a lawyer . . . may pay the usual charges of a not-for-profit lawyer referral service or other legal service organization." that a lawyer may "request referrals from a lawyer referral service oper-

spend their fees for any legitimate purpose, including any of the legitimate activities of the organization that employs them. However, we must still distinguish between donations and contractual obligations to share fees. Even though a law firm may donate its money for any legitimate purpose, it may not contract to share fees with a nonlawyer, no matter how noble the nonlawyer's purpose. See supra text accompanying note 22.

88. MODEL Rules, supra note 5, Rule 5.4(a)(3). The Code contained a virtually identical provision. See MOdel CodE, supra note 5, DR 3-102(A)(3).

89. The other two express exceptions in Rule 5.4(a) and its substantially identical Code counterpart, DR 3-102(A), concern only deceased lawyers and are irrelevant to public interest groups. See supra note 5 (quoting Rule 5.4(a)).

90. MODel Rules, supra note 5, Rule 7.2(c) (emphasis added). The comment to Rule 7.2(c) does not discuss or explain this language. Under California's newly revised ethical rules, the referral service exception is part of the rule prohibiting fee sharing with nonlawyers. See California Rules of Professional Conduct Rule 1-320(A)(4) (1989) (rule entitled "Financial Arrangements With Non-Lawyers" provides that lawyer "may pay a prescribed registration, referral, or participation fee to a lawyer referral service"). 
ated, sponsored, or approved by a bar association and may pay its fees incident thereto." A A related provision allows a lawyer to be "recommended, employed, or paid by . . . [a]ny bona fide organization that recommends, furnishes, or pays for legal services to its members or beneficiaries" as long as the organization derived "no profit" from the rendition of legal services. ${ }^{92}$

Groups such as the ACLU or the NAACP are legal service organizations within the meaning of Rule 7.2(c), and are "bona fide" organizations that recommend, furnish, or pay for legal services within the meaning of the Code. ${ }^{93}$ The difficult question is whether a lawyer's ethical right to pay the "usual charges" or "fees incident to" a legal service organization encompasses the right to enter into a fee-sharing agreement with a public interest organization. Do these terms imply an exception to the fee-sharing rule allowing contracts to share fees with public interest groups? ${ }^{94}$ The Rules and the Code do not answer these questions, ${ }^{95}$ but a few cases and ethics opinions shed some light on them.

91. MODEL CoDE, supra note 5, DR 2-103(C)(1) (footnote omitted). That section is generally irrelevant to lawyers working with public interest organizations, however, since such organizations are not ordinarily operated, sponsored, or formally approved by bar associations. California, however, has adopted standards for approving lawyer referral services. See Calrfornia Rules of Professional Conbuct Rule 1-600(B) (1989) ("The Board of Governors of the State Bar shall formulate and adopt Minimum Standards for Lawyer Referral Services, which . . . shall be binding on members.").

92. Model CoDE, supra note 5, DR 2-103(D)(4). The Code also requires that there be "no interference with the exercise of independent professional judgment" on behalf of the lawyer's client, id. DR 2-103(D), and (perhaps redundantly) that "[t]he member or beneficiary to whom the legal services are furnished, and not such organization, is recognized as the client of the lawyer in the matter," id. DR 2-103(D)(4)(d).

93. The Model Rules define a number of terms, but they do not define "legal services organization." See Model Rules, supra note 5, terminology section (immediately preceding Rule 1.1). The comment to Rule 7.2 does not even use that phrase. See id. Rule 7.2 comment ("[A] lawyer may participate in not-for-profit lawyer referral programs and pay the usual fees charged by such programs."). The Model Rules commentary says that DR 2-103(D) "referred to legal aid and other legal services organizations." See id. Rule 7.2 comparison section (emphasis added). In fact, however, DR 2-103(D) does not refer to "legal services organizations" per se. Rather, DR 2-103(D) refers to "[a]ny bona fide organization that recommends, furnishes, or pays for legal services to its members or beneficiaries." See MODEL CODE, supra note 5, DR 2-103(D)(4). The meaning of that language is therefore important to understanding the phrase "legal services organization" in Model Rulc 7.2(c).

The Code does not define a "bona fide organization that recommends, furnishes or pays for legal services," but a footnote cites United Mine Workers v. Illinois State Bar Ass'n, 389 U.S. 217 (1967); Brotherhood of R.R. Trainmen v. Virginia ex rel. Virginia State Bar, 377 U.S. 1 (1964); and NAACP v. Button, 371 U.S. 415 (1963) (all of which are discussed infra text accompanying notes 270-85). MODEL CODE, supra note 5, DR 2-103(D)(4) n.87. Citations to these cases suggest that the drafters had a broad range of nonprofit organizations in mind, including public interest groups like the NAACP.

94. If the exception were explicit, Rule 5.4(a) would say: " $A$ lawyer serving as a staff attorney or cooperating attorney for a not-for-profit lawyer referral service, public interest organization, or other legal services organization may share with the organization all or part of any court-awarded attorney fees based on the performance of legal services for clients referred or sponsored by the organization." The exception might also depend on certain conditions, such as those proposed by the Kutak Commission. See supra note 64 (paras. (a)-(d)).

95. The comment to Rule 7.2(c) says only that "a lawyer may participate in not-for-profit lawyer referral programs and pay the usual fees charged by such programs." MODEL Rules, supra note 5 , Rule 7.2(c) comment. The Ethical Considerations to Canon 2 of the Code do not define or explain the word "profit" in DR 2-103(D), but in this context it is logical to define it as the excess of returns over 
In Formal Opinion $291,^{96}$ and again in Informal Opinion $1076,{ }^{97}$ the ABA stated that a bar association's lawyer referral service may ethically require referral panel members to pay a reasonable percentage of the fees that the lawyers collect in referred cases. In line with these opinions, at least forty state and local bar associations require attorneys to give their lawyer referral services a percentage of their fees. ${ }^{88}$

Nevertheless, some lawyers have voiced concern that these percentageof-the-fee requirements violate the prohibition against fee splitting with nonlawyers. ${ }^{\theta \theta}$ These ethical concerns generated litigation in Emmons, Williams, Mires E Leech $v$. State Bar. ${ }^{100}$ There, an attorney registered with a bar's lawyer referral service and agreed to give the service onethird of any resulting fees. ${ }^{101}$ After collecting a $\$ 48,000$ fee on a malpractice referral, however, the lawyer decided that the arrangement "would constitute fee-splitting with an unlicensed person."102 Citing ABA approval of fee sharing as a method of financing lawyer reference services, ${ }^{103}$ the court rejected this argument: "The bar association seeks not individual profit but the fulfillment of public and professional objectives. It has a legitimate, nonprofit interest in making legal services more readily available to the public."104

Read broadly, this rationale applies equally to nonprofit public interest organizations because their goal is also to make legal services more readily available to the public, not to let individuals profit by sharing referral fees. But when read more critically, it does not fully apply to public interest groups because they take a much more active role than referral services

expenditures in a given transaction or series of transactions. To the extent that a fee award exceeds an organization's cost of providing a staff or cooperating attorney, the organization would derive a "profit" from the rendition of legal services.

96. ABA Comm. on Professional Ethics and Grievances, Formal Op. 291 (1956), reprinted in american Bar Association, Opinions of the Committee on Professional Ethics and Grievances 624 (1957). The opinion interpreted the term "lawyer" in Canon 34, which provided that no division of fees for legal services was proper except with "another lawyer." Since a referral service is not "another lawyer," the opinion apparently expresses an implied exception to the rule against fee sharing, based on the bar's duty to make legal services more widely available to the public. See ABA Comm. on Professional Ethics and Grievances, Formal Op. 205 (1940), reprinted in AMERican Bar association, Opinions of the Committee on Professional Eithics and GrievANCES 416, 418 (1957) (recognizing "an obligation of the profession [to provide] competent legal services to persons in low-income groups at fees within their ability to pay").

97. ABA Comm. on Professional Ethics, Informal Op. 1076 (Oct. 8, 1968), reprinted in INFormal Opinions of the Committee on Professional Ethics (ABA) (1969).

98. See American Bar association Lawyer Referral and Information Service ComMITTEE, REFERENCE HANDBOOK 41-42 (1986) (listing 48 bar association referral services having feesharing arrangements); LRS In a Time of Change, B. LEADER, May-June 1982, at 4-5.

99. LRS In a Time of Change, B. LEADER, May-June 1982, at 5-6 (reporting fee-sharing concerns in Florida and Ohio).

100. 6 Cal. App. 3d 565, 86 Cal. Rptr. 367 (1970).

101. 6 Cal. App. 3d at 568, 86 Cal. Rptr. at 368.

102. 6 Cal. App. 3d at 567-68, 86 Cal. Rptr. at 368.

103. 6 Cal. App. 3d at 572 n.5, 573-74, 86 Cal. Rptr. at 371 n.5, 371-73 (citing ABA Formal Op. 291 and California's Minimum Standards for a Lawyer Reference Service in California).

104. 6 Cal. App. 3d at 574, 86 Cal. Rptr. at 372-73. 
in soliciting clients and retaining involvement in the cases. Thus, the opportunity and temptation to increase a share of the fees is a greater danger for public interest organizations than for bar-operated referral services.

Perhaps for these reasons, some recent ethics opinions suggest that nonprofit lawyer referral services not sponsored by bar associations cannot ethically receive a share of the legal fees from referred cases. A 1985 informal ABA ethics opinion, for example, considered a religious corporation's proposal to establish a nonprofit "national network" of lawyers interested in providing legal services to missionaries and their dependents. ${ }^{105}$ The ABA concluded that the plan was proper under Rule 7.2(c) "provided there is no sharing of legal fees with the Organization and no interference with the lawyer's professional judgment in rendering legal services to the client." ${ }^{108}$ A 1985 District of Columbia ethics opinion echoes these themes. ${ }^{107}$

While pertinent, these opinions fail to address several elements common to fee-sharing arrangements between lawyers and public interest organizations. These missing elements cut in opposite directions. On the one hand, the lawyer referral services opinions do not consider situations in which staff or cooperating attorneys agree to pay over all of their fees to the organizations. Yet the phrases "usual charges" and "incidental fees" cannot mean all fees resulting from referred cases, ${ }^{108}$ and the highest percentage currently charged by any bar-operated referral service is only twenty-five percent. ${ }^{109}$ On the other hand, the referral service opinions do not discuss court-awarded attorney fees, whose public policy implications favor public interest groups. ${ }^{110}$ Since the rules themselves do not provide any clear exception for public interest groups, we must ask whether the fee-award statutes themselves provide an avenue around the fee-sharing rule.

105. ABA Comm. on Ethics and Professional Responsibility, Informal Op. 1512 (Mar. 26, 1985), reprinted in [Ethics Opinions] Law. Man. on Prof. Conduct (ABA/BNA) 801:368 (1985). The organization's plan was to contact potential clients to promote the referral service, and to give the names of registered lawyers to those wishing to use the service. See id. at 368-69.

106. Id. at 369 (citing Rule 5.4(a), (c)) (emphasis added). The ABA also concluded that the proposed plan would not violate DR 2-103. Id. at 369-70.

107. See D.C. Bar Comm. on Legal Ethics, Formal Op. 155 (June 18, 1985), reprinted in [19871 Transfer Binder] Nat'l Rep. on Legal Ethics \& Prof. Resp. (UPA) DC:OPINIONS:3.

108. The ABA has permitted lawyers to pay referral services only a "reasonable" percentage of their fees. See supra text accompanying notes 90-98.

109. See American Bar Association Lawyer Referral and Information Service ComMITTEE, REFERENCE HANDBOOR 41-42 (1986) (describing fee-sharing arrangements used by state and local bar association lawyer referral services). The highest figure, 25\%, is charged by the Bar Association of San Francisco Lawyer Referral Service, and applies only to contingent fee recoveries of $\$ 20,000$ or more. Id. at 41 . In the Emmons case, which reviewed two surveys of bar association referral services in the 1960's, the court found that the one-third referral fee at issue was "the highest in the United States." 6 Cal. App. 3d at 574, 86 Cal. Rptr. at 373.

110. See infra text accompanying note 143 . 


\section{The Effect of Federal Fee-Shifting Statutes}

The rule against fee sharing developed long before federal fee-shifting statutes began to play a prominent role in public interest litigation. ${ }^{111} \mathrm{Be}-$ cause federal statutes implicate the supremacy clause, and because courts have crafted a special rule to address fee sharing between staff attorneys and nonprofit groups, we need to explore the effect of federal fee-shifting statutes on the fee-sharing rule.

\section{A. The Supremacy Clause}

Under the supremacy clause of the Constitution, ${ }^{112}$ federal laws take precedence over any conflicting state laws. ${ }^{113}$ Therefore, if federal feeshifting provisions mandate fee awards directly to public interest groups that provide counsel, or if Congress clearly intended that the fee-shifting provisions would override the rule against fee sharing, then the states could not prohibit attorneys from sharing fees with public interest groups.

Unfortunately, the cases and legislative history on the relationship between fee-shifting statutes and the fee-sharing rule are inconclusive. Both before and since the passage of the Civil Rights Attorney's Fees Awards Act of $1976^{114}$ (section 1988), for example, courts have issued conflicting decisions about who is to receive fee awards when public interest groups provide counsel.

In Wilderness Society $v$. Morton, ${ }^{116}$ an en banc opinion written by the late J. Skelly Wright, three environmental groups had won a suit to block construction of the trans-Alaska pipeline. Congress had not yet passed a fee-shifting provision for environmental suits, but the court awarded fees under the common law "private attorney general" doctrine. ${ }^{116}$ However, the court expressly awarded the fees to the staff attorneys, not to the groups that employed them. In the court's view, this procedure avoided "all problems of whether the organization might, by receiving an award directly, be involved in the unauthorized practice of law."117

111. See supra text accompanying notes 25-71.

112. U.S. CoNST. art. VI, cl. 2 (providing that "the laws of the United States . . shall be the supreme Law of the Land; and the Judges in every State shall be bound thereby, any Thing in the Constitution or Laws of any State to the Contrary notwithstanding").

113. See, e.g., Pennsylvania v. Nelson, 350 U.S. 497, 501-10 (1956) (describing analytical framework); see also Felder v. Casey, 108 S. Ct. 2302, 2314 (1988) (holding that Wisconsin procedural rule conflicting with federal civil rights laws was void under supremacy clause).

114. 42 U.S.C. $\S 1988$ (1982).

115. 495 F.2d 1026 (D.C. Cir. 1974) (en banc) (holding that federal courts generally cannot award fees without statutory authority from Congress), rev'd on other grounds sub nom. Alyeska Pipeline Serv. Co. v. Wilderness Soc'y, 421 U.S. 240 (1975).

116. Id. at 1029-30. The reversal of this decision in Alyeska, prompted Congress to enact section 1988.

117. Id. at 1037. The organizations that brought the suit were parties, not just sponsors of the litigation, but the court believed it had to award fees to the lawyers rather than to the organizations "whether such organization is a litigating party or a public interest law firm or defense fund." Id. There was no agreement between the staff attorneys and the organizations concerning fees; the court 
In dictum, the court added that the lawyers could not keep the entire fee award, because equity required them to reimburse their organizations for the portion of their salaries and overhead related to the case. ${ }^{118}$ But the court said: "[A]ny amount in excess of such reimbursement belongs to counsel themselves. That excess may, in whole or in part, be contributed to the organization involved, or to like causes, or retained by counsel . . . ."118 The Supreme Court later overturned the fee award in Wilderness Society without reaching the question of who should have received the fees, ${ }^{120}$ but those who oppose fee sharing with public interest groups still cite Wilderness Society. ${ }^{121}$

Other courts awarded common law fees directly to public interest groups. A good illustration is Torres $v$. Sachs, ${ }^{\mathbf{1 2 2}}$ where the plaintiffs' lawyers were employed by a nonprofit public interest group, the Puerto Rican Legal Defense and Education Fund, Inc.. ${ }^{123}$ The district court awarded fees at full market rates ${ }^{124}$ directly to the group, ${ }^{125}$ and the court of appeals affirmed, noting that "[n]on-profit public interest law firms have been recognized as properly entitled to attorneys' fees." ${ }^{126}$ Similarly, in Fairley $v$. Patterson ${ }^{127}$ attorneys employed by a public interest group

found no reason to believe that the plaintiffs had given "any thought whatever to the possibility of a fee award." Id. at 1037 n.9. The court also thought staff attorneys should be allowed to keep all of the fees in excess of the reimbursement level because their salaries were probably "less than they could have earned on the market in the absence of their dedication to the public interest." Id at 1037. This rationale is unconvincing. Lawyers accept relatively low salaries from public interest groups because they derive satisfaction from serving the public interest. Fee awards on top of the salary would thus unjustly enrich staff attorneys at the expense of the organizations they serve.

118. Id at 1037. The court described the overhead as all expenses normally included in an attorney's fee, such as secretarial services and office supplies.

119. Id; see supra text accompanying note 22. If donations violated the fee-sharing rule, lawyers could never donate money traceable to their receipt of fees. For lawyers who derive most of their income from fecs, this would preclude nearly all charitable donations.

120. The Court reversed Wilderness Society on the grounds that no fees should have been awarded to anyone. See Alyeska, 421 U.S. at 269-71. The Alyeska Court did not examine or discuss the appellate court's allocation of fees between the attorneys and their employers, and nothing in the opinion endorses (or disputes) the rule allowing attorneys to keep all fees above the organization's cost.

121. See Devine v. National Treasury Employees Union, 805 F.2d 384, 388-89 (Fed. Cir. 1986) (citing Wilderness Society for proposition that if unions do not establish funds fully supportive of their litigation activities, court could award fees directly to attorneys), cert. denied, $108 \mathrm{~S}$. Ct. 67 (1987); Munsey v. Federal Mine Safety \& Health Review Comm'n, 701 F.2d 976, 977 n.1 (D.C. Cir.) (citing Wildermess Society for proposition that staff attorneys receiving fee awards personally must reimburse their employers for expenses, including their salaries), cert. denied, 464 U.S. 851 (1983); National Treasury Employees Union v. United States Dep't of the Treasury, 656 F.2d 848, 852 \& n.39 (D.C. Cir. 1981) (asserting that obedience to fee-sharing rule is "expressly required" by Wilderness Society).

122. 69 F.R.D. 343 (S.D.N.Y. 1975), affd, 538 F.2d 10 (2d Cir. 1976).

123. See 538 F.2d at 11 (listing counsel); 69 F.R.D. at 346 (giving counsel's biographies).

124. See 69 F.R.D. at 346 (awarding fees at "the hourly amount to which attorneys of like skill in the area would typically be entitled" " (quoting City of Detroit v. Grinnell Corp., 495 F.2d 448, 471 (2d Cir. 1974))).

125. 69 F.R.D. at 348 (ordering fees "to be paid by defendants to the Puerto Rican Legal Defense Fund").

126. 538 F.2d at 13 (citations omitted).

127. 493 F.2d 598 (5th Cir. 1974). 
successfully challenged a reapportionment plan. The district court denied fees because the group's staff attorneys had assigned all fees to the group, ${ }^{128}$ but the court of appeals reversed, saying: "Whether the attorney charges a fee or has an agreement that the organization that employs him will receive any awarded attorneys' fees are not bases on which to deny or limit attorneys' fees or expenses."129

From the perspective of the policy underlying federal fee-shifting statutes, Torres and Fairley are preferable to Wilderness Society. ${ }^{130}$ If the fee-sharing rule gave staff attorneys the right to keep all fees exceeding a group's cost (as Wilderness Society implies), the resulting loss of revenue might force public interest groups to lay off staff attorneys or pay lower salaries. Either result might drive many lawyers out of the public interest sector altogether, ${ }^{131}$ making it harder for public interest groups to educate the public, sponsor cases, file amicus briefs, train cooperating attorneys, and carry on other activities. Awarding fees directly to public interest groups (as in Torres) or allowing attorneys to assign fee awards to public interest groups (as in Fairley) at least diminishes this threat to the practice of public interest law.

Congress did not expressly consider these implications in passing section 1988, but the House report on section 1988 cites Torres and Fairley with approval in a terse footnote. ${ }^{\mathbf{1 3 2}}$ Citing this footnote, the Supreme Court stated in New York Gaslight Club, Inc. v. Carey" that "Congress endorsed such decisions allowing fees to public interest groups when it was considering, and passed [section 1988]." "134 But this dictum overstates Congress' use of Torres and Fairley. The House Report cited those cases not to support fee awards to public interest organizations, but rather for the proposition that "a prevailing party is entitled to counsel fees even if represented by an organization."135 This tracks the language of section 1988 , which allows courts to award fees only to a prevailing party. ${ }^{136}$

128. See id. at 605 (quoting unpublished district court opinion).

129. Id. at 607 (emphasis added, footnote omitted). The footnote suggested that denying or limiting statutory fees to nonprofit groups "might raise other issues of constitutional dimension," including equal protection issues. Id. at 607 n.14. Equal protection issues are beyond the scope of this Article.

130. For a discussion of policy issues from the perspective of legal ethics, see infra text accompanying notes 203-59.

131. See supra text accompanying notes 17-19 (reporting empirical data).

132. See H.R. REP. No. 1558, 94th Cong., 2d Sess. 8 n.16 (1976) [hereinafter H.R. REP. No. 1558]. The report does not cite specific language from either case, so the import of the citations is ambiguous. The Senate report does not cite Torres or Fairley at all, and never mentions direct awards to groups or the problem of fee sharing with groups that include nonlawyers. See S. REP. No. 1011, 94th Cong., 2d Sess. (1976), reprinted in 1976 U.S. CODE CONG. \& ADMIN. NEws 5908, 5909.

133. 447 U.S. 54 (1980).

134. Id. at $70 \mathrm{n} .9$ (emphasis added).

135. H.R. ReP. No. 1558, supra note 132 , at 8 n.16.

136. See 42 U.S.C. $\S 1988$ (1982). All other federal fee-shifting statutes likewise award fees to the prevailing party. No federal fee-shifting statute awards fees directly to the prevailing attorney or sponsoring organization. See Marek v. Chesny, 473 U.S. 1, 43 (1985) (appendix to Brennan, J., dissenting) (listing more than 100 federal fee-award statutes).

The discussion here does not concern the situation in which public interest groups are actually 
Congress could have allowed fees to the plaintiff's attorney ${ }^{137}$ or to the sponsoring organization, ${ }^{138}$ but Congress chose instead to award fees only to the prevailing party.

This choice was recently emphasized by the Supreme Court in Evans v. Jeff $D .{ }^{138}$ There, a Legal Aid staff attorney challenged the defendant's right to condition a class action settlement on the plaintiff's waiver of all fees under section 1988. The Court held that the clients could waive the right to a fee award because "the language of the Act, as well as its legislative history, indicates that Congress bestowed on the 'prevailing party' . . . a statutory eligibility for a discretionary award of attorney's fees."140 In dictum, Evans added that parties could assign their fees to their attorneys, because Congress never "legislated against assignment of this right to an attorney."141 But two key questions remain. If clients do assign their fees to attorneys, does section 1988 allow attorneys to assign their fees to public interest organizations even though the assignment violates state ethical rules against fee sharing with nonlawyers? Alternatively, does section 1988 allow clients to assign fee awards directly to organizations, even though the assignment also technically violates the fee-sharing rule?142

parties to litigation. When a public interest group is itself a party, it may be entitled to fees for providing its own counsel. Under the Equal Access to Justice Act, for example, tax-exempt nonprofit organizations that prevail in litigation against the government are expressly eligible for attorney fee awards. See 28 U.S.C. \$ 2412(d)(1)(A) (1982 \& Supp. IV 1986). But see supra text accompanying notes 115-19 (under Wilderness Society, even public interest groups acting as parties could not receive fees directly under the common law private attorney general doctrine).

137. In other contexts, some model acts provided for fees to be awarded directly to attorneys. See, e.g., UNIF. Consumer CRedit CoDe $\S 5.201$ (8) (Official Text 1974) (if creditor has violated Act, "the court shall award to the consumer the costs of the action and to his attorneys their reasonable fees" (emphasis added)).

138. Various model acts have advocated awarding fees directly to nonprofit groups. See, e.g., Model Consumer Credit ACT \$ 8.113(3) (National Consumer Law Center 1974 Draft) ("If the consumer is represented by an attorney employed by a non-profit organization, the organization is entitled to the same amounts to which a private attorney would be entitled." (emphasis added)); National Consumer ACT $\S 5.307$ (1) (National Consumer Law Center 1st Final Draft 1970) ("If the consumer is represented by a non-profit organization, . . . the organization shall be awarded a service fee, in lieu of attorney's fees, equal to the amount of fees a private attorney would be awarded for the same services." (emphasis added)).

139. 475 U.S. 717 (1986).

140. Id. at 730 (emphasis in original). Justice Brennan vehemently dissented. See id. at 743 (Brennan, J., dissenting).

141. Id. at 731. Thus, a client could properly assign his fee award to a staff or cooperating attorney for a public interest group.

142. An attorney may have the right to waive a fee entirely, but the attorney cannot nominally "waive" fees and simultaneously allow the client to assign the "waived" fees to a nonlawyer. That would enable attorneys to evade the fee-sharing prohibition too easily. See, e.g., In re O'Neill, 5 F. Supp. 465, 467 (E.D.N.Y. 1933) (lawyer violated rule against fee sharing by having client pay $15 \%$ of recovery to lawyer and $5 \%$ directly to union that referred case to lawyer); Committee on Professional Ethics and Conduct v. Lawler, 342 N.W.2d 486, 488 (Iowa 1984) (lawyer violated rule against fee sharing by having client pay hourly fees directly to paralegal). Since an agreement that violates the rules of ethics is void as contrary to public policy, a court could not honor any underlying assignment of fees to a nonlawyer. See O'Hara v. Ahlgren, Blumenfeld and Kempster, No. 65,760 (Ill. Mar. 29, 1989) (WESTLAW, IL-CS database) (refusing to enforce fee-sharing agreement with nonlawyer on grounds that agreement violated public policy). See generally J. Calamari \& J. Perilro, ConTRACTS $\S 22-1$, at 889 (3d ed. 1987) (illegal bargains generally unenforceable). As in Wilderness Society, lawyers would have to reimburse their employers for their costs, but the lawyers could keep 
Congress never directly addressed these questions. If Congress had addressed them, I believe it would have allowed parties or their attorneys to assign fees to public interest groups, whether or not such assignments violate the fee-sharing rule. Such assignments would be consistent with the principal purpose of section 1988, which was to increase the availability of lawyers taking civil rights cases. ${ }^{143}$ But nothing in the legislative history of section 1988 clearly expresses this intent, and under the Supreme Court's supremacy clause jurisprudence a statute's broad purpose is not sufficient to override a state rule. ${ }^{144}$ Accordingly, given the ambiguous legislative history and the complete silence in the statutory language, section 1988 apparently will not nullify state ethical rules that forbid assignment of fees to public interest groups. ${ }^{145}$ However, courts have developed an exception that might allow public interest groups to receive statutory fees without violating the rule against fee sharing with nonlawyers. That exception involves separate litigation funds, which are discussed next.

\section{B. Separate Litigation Funds}

\section{National Treasury Employees Union and Its Progeny}

In National Treasury Employees Union v. Department of the Trea$\operatorname{sury}^{\mathbf{1 4 8}}(N T E U)$, a union-sponsored prepaid legal services plan employed full-time, salaried staff lawyers who had agreed to turn over all courtawarded fees to the union's general treasury. ${ }^{147}$ But when a staff attorney won a suit for a union member under the Privacy Act, which provided for a fee award, the district court refused to award fees at prevailing market

the excess or donate it to their employers or to other groups. See supra text accompanying notes 115-19.

143. See H.R. REP. No. 1558, supra note 132, at 3 ("[P]rivate lawyers were refusing to take certain types of civil rights cases because the civil rights bar, already short of resources, could not afford to do so.").

144. See Commonwealth Edison Co. v. Montana, 453 U.S. 609, 633-34 (1981) (preemption of state law by federal statutes is not favored unless nature of subject matter allows no other conclusion or unless Congress has unmistakably so provided). See generally L. TRIBE, AMERICAN ConstTTUTIONAL. LAw $\$ 2-25$, at 479-81 (2d ed. 1988) (noting Court's apparent "overriding reluctance to infer preemption in ambiguous cases").

145. But courts will scrutinize the allegation of such a purpose to determine whether it truly reflects congressional intent. See National Treasury Employees Union v. Department of the Treasury, 656 F.2d 848, 855 (D.C. Cir. 1981) ("We do not imply, of course, that Congress could not assign the considerations at stake values different from those ascribed by the legal profession. It suffices merely to observe that for cases like the one before us, Congress has not done so.").

146. 656 F.2d 848 (D.C. Cir. 1981). An earlier opinion in the same case, Anderson v. Department of the Treasury, 648 F.2d 1, 3 (D.C. Cir. 1979) (per curiam), had held that "no fee exceeding the expenses incurred by the union-in terms of attorney's salaries and other out-of-pocket expenses-should be allowed." Shortly thereafter, however, the D.C. Circuit decided a related issue involving attorney fees in Copeland v. Marshall, 641 F.2d 880 (D.C. Cir. 1980) (en banc). The Anderson panel then decided, sua sponte, to issue "a supplemental opinion elaborating on the principles underlying [Anderson], and on the limited nature of our holding." NTEU, 656 F.2d at 850 . I discuss only the supplemental opinion.

147. See 656 F.2d at 849; see also id. at 850 ("At oral argument, union counsel told us that the entire fee recovery would be turned over to their employer [the union]."). 
rates. Instead, the court awarded only the union's actual financial outlay for providing the staff attorney's services. ${ }^{148}$ The court of appeals affirmed. ${ }^{149}$ If the union received a fee award in excess of the union's actual costs of providing legal services, the court said, the union would be making an unethical "profit" on legal services. ${ }^{150}$ This "profit" would violate the prohibition against sharing fees with nonlawyers. ${ }^{151}$

The NTEU court, however, intended no harm to public interest organizations that depended on court-awarded fees for funding. ${ }^{182}$ The court said that its "very narrow" holding would not damage the public interest bar, and would not affect prior opinions awarding market rate fees directly to public interest groups. ${ }^{\mathbf{1 5 3}}$ Unlike unions, the court said, public interest organizations focused strictly on litigation, not on the "diverse operations" funded by unions. ${ }^{154}$ The rules of legal ethics permitted lawyers to divide fees with other members of their law firms, and the "same principle leaves a salaried attorney at liberty to surrender his fees to a public interest organization dedicated entirely to litigative activities."185 Market rate fee awards to public interest organizations would thus be "plowed back into the litigative programs that made their recovery possible in the first place."186

The implication of $N T E U$ is that lawyers may ethically agree to share market rate legal fees with public interest groups as long as the fees are used solely to finance more litigation. ${ }^{157}$ Before a public interest group can demand that its staff attorneys or cooperating attorneys turn over fees awarded at market rates, therefore, the group apparently must maintain a separate "litigation fund."158

148. See id. at 849 (summarizing unpublished opinion).

149. Because the union was ultimately to receive any fee award, the court viewed the union as the "real party in interest" and granted the union's motion for substitution as appellant. Id. at 850-51 \& n.23.

150. Id. at 851 (quoting DR 2-103(D)(4)(a), which provides that lawyers cannot work for legal services organization unless it derives "no profit" by rendering legal services).

151. Id. at 851-52. The court also asserted that profiting from the work of staff attorneys would involve the union in the unauthorized practice of law. See id. at $852 \mathrm{n.37}$ ("Since a lawyer should not aid or encourage a layman to practice law, he should not . . . share . . . fees with a layman." " (quoting MOdel Code, supra note 5, EC 3-8)).

152. Amici, including the Lawyers' Committee for Civil Rights Under Law, had offered the "apocalyptic scenario" that refusing to award market rate fees would "destroy the public interest bar by squeezing out of existence those legal aid organizations that depend on court-awarded . . . fees." 656 F.2d at 853 \& n.48.

153. Id. at 853-54 \& $\mathrm{n} .49$ (citing cases from nine circuits awarding market rate fees to legal aid offices or public interest organizations). For a discussion of some of the cited cases, see supra text accompanying notes $122-29$.

154. 656 F.2d at 854 .

155. Id. (emphasis added).

156. Id.

157. The court also said that full market rate fees would be proper if the fees became the attorney's own money. Id. at 855 .

158. Because the National Treasury Employee's Union itself did not maintain a special fund dedicated solely to litigation, the court did not have to decide whether courts could properly award market rate fees to nonprofit groups that maintained such funds. The court said only that "perhaps" 
Many opinions have followed NTEU. ${ }^{159}$ The most important for public interest organizations is Jordan v. United States Department of Justice, ${ }^{\mathbf{1 0 0}}$ which held that lawyers employed by a law school's clinical program ${ }^{101}$ were to be awarded fees at full market rates. ${ }^{162}$ In a long footnote frequently citing $N T E U$, the court said:

We assume for purposes of this appeal that, should the Institute share in any attorneys' fee award beyond recoupment of its own expenses, it will maintain a fund exclusively for litigation, into which its share will be deposited. . . . [I]t is improper for an entity not licensed to practice law to partake in attorneys' fees representing the market value formula . . . where its portion is not to be placed in a fund dedicated solely to litigation. ${ }^{\mathbf{1 6 3}}$

An informal Nebraska ethics opinion has followed NTEU and Jordan. The Nebraska ACLU affiliate, the NCLU, required cooperating lawyers to turn over thirty-five percent of any fee award in NCLU cases. The NCLU deposited all fee awards into "a segregated fund" used "exclusively for litigation purposes."164 In the NCLU's view, this segregated

full market rate fee awards "would withstand criticism when the monies are directed into a fund for maintenance of a legal services program." Id. But the opinion clearly approved of market rate awards to lawyers working for public interest organizations that maintained separate funds for litigation.

159. See, e.g., Munsey v. Federal Mine Safety \& Health Review Comm'n, 701 F.2d 976, 977 (D.C. Cir.) ("If attorney fees are awarded to the union itself rather than its attorney, the union can only recoup the expenses it incurred in supplying services to the client . . . ."), cert. denied, 464 U.S. 851 (1983); Powell v. Department of the Treasury, 8 M.S.P.B. 21, 27 (1981) (where any award of attorney's fees is forwarded to union under employment contract, union-paid lawyer representing union member can recover "no more than the actual cost of the union in providing legal services" to member). Munsey distinguished fees personally awarded to an attorney: "If attorney fees are awarded to the attorney alone (and not for the union's general treasury), the attorney is entitled to receive the market value of the services rendered." 701 F.2d at 977 (citing NTEU).

160. 691 F.2d 514 (D.C. Cir. 1982).

161. The program was the Institute for Public Representation, which is affiliated with Georgetown University Law Center. The court described the Institute as "a qualified clinical program." Id. at 516 n.14. The court did not explain the word "qualified"; perhaps it meant "bona fide"-that is, not set up by nonlawyers for the purpose of improperly reaping profits from the practice of law. See supra note 83 (discussing meaning of "qualified legal assistance organization" in Code).

162. 691 F.2d at 521 (remanding to determine "the rate prevailing in the community for similar legal work"). The opinion was written by Judge Spottswood Robinson, III, author of the NTEU opinion.

163. Id. at 516 n.14 (emphasis added, citations omitted). The court went on to say that an entity without a separate fund "would participate in a long-prohibited division of fees with an attorney" if it received fees at market rates. Id. Citing Wilderness Society, however, the court said:

[A] market-value award can be made directly to the lawyer who served at the instance of the organization. The lawyer might then come under an equitable obligation to reimburse the organization for its expenses, and would be free to donate any part of the fee to the organization-just as he could donate monies obtained from other sources. Id. (citations omitted).

164. Letter from George Green, then President of the NCLU, to Robert Barlow, Advisory Opinion Comm., Nebraska State Bar Ass'n (July 9, 1984) (on file with author). The letter also said that fees shared with the NCLU could be characterized as "referral fees" permitted under the Nebraska equivalent of Rule 7.2(c). See also Nebraska Code of Professional Responsibility DR 2103(A) (1983) (containing referral service language modeled on Rule 7.2(c)); Advisory Comm. of the Nebraska State Bar Ass'n, Op. 83-4 (1983), reprinted in [1984-1 Transfer Binder] Nat'l Rep. on 
fund satisfied the standards in NTEU and Jordan. The state bar ruled that the fee-sharing arrangement was not unethical. ${ }^{185}$

\section{Evaluating the Separate Litigation Fund Concept}

The theory underlying separate litigation funds is that "[w]hen fees are paid into a separate account used solely by lawyers for litigation purposes, there simply is no fee splitting with a lay entity."166 This explanation, however, confuses ethics and policy. The condition that fees be "used solely by lawyers" correctly states the requirement of the rules of legal ethics. Absent any actual use of legal fees by nonlawyers, the rule against fee sharing is not violated. ${ }^{\mathbf{1 6 z}}$

However, the condition that lawyers use the fees "for litigation purposes" is not required by the ethical rules, which place no such restriction on the ways in which lawyers may use their fees. ${ }^{168}$ The "litigation only" condition in the NTEU line must therefore be based on the policy of the fee-shifting statutes-to increase the supply of lawyers willing to handle public interest cases. ${ }^{169}$ But restricting the use of fee awards to litigation funds is debatable. ${ }^{170}$ On the one hand, maintaining a separate fund devoted exclusively to litigation is not difficult, ${ }^{171}$ and many public interest groups have already created separate litigation funds to receive attorney fee awards. ${ }^{172}$ A separate fund is basically a bookkeeping entry, and

Legal Ethics \& Prof. Resp. (UPA) NE:OPINIONS:10 (lawyer may pay usual charges to nonprofit lawyer referral service).

165. See Letter from John G. Taylor, NCLU Director, to James Long, ACLU of Florida Executive Director (July 25,1988 ) (on file with author) ("The State Bar Association has determined that our system of sharing fees is not in violation of DR 2-103." (emphasis in original)). The D.C. Bar's Legal Ethics Committee reached a similar conclusion in $N T E U$ 's original context, ruling that the prohibition against fee sharing allows market rate fee awards to a union "where market value fees are placed in a separate fund to be used solely by the union's lawyers to finance legal assistance, even if the umbrella organization receives some indirect benefit from this arrangement." D.C. Comm. on Legal Ethics, Formal Op. 176 (Oct. 21, 1986), reprinted in District of Columbia BAR Legal Ethics Commitree Opinions 291, 292. The Ethics Committee interpreted the phrase "exclusively for litigation" in Jordan to include "funds maintained exclusively for legal assistance that involves legal work other than just litigation." Id. at 291 n.2. It is unclear whether "legal assistance" would include educational programs, lawyer training, or other nonlitigation activities, but that would be stretching the term "legal assistance" far beyond its ordinary meaning.

166. Curran v. Department of the Treasury, 805 F.2d 1406, 1409 (9th Cir. 1986) (emphasis added).

167. See supra text accompanying notes 83-87 (discussing definition of "law firm" in Model Code and Model Rules).

168. See supra text accompanying notes 86-87 (describing restrictions on use of fees).

169. See supra note 143 (quoting legislative history of section 1988).

170. This Article does not address whether separate litigation funds are justified in the context of union-prepaid legal services programs. However, my policy analysis may also apply to unions.

171. Cf. Regan v. Taxation with Representation, 461 U.S. 540, 544 n.6 (1983) (burden of maintaining separate organizations for lobbying and for tax-exempt nonlobbying activities is not great).

172. According to my survey, almost $45 \%$ of all ACLU affiliates (22 of 50 ) now maintain separate litigation funds into which they deposit all court-awarded fees. Among other public interest groups, nearly $40 \%$ maintain separate litigation funds. However, a group's assertion that it maintains a separate fund does not guarantee market rate fees because courts, staff attorneys, and defendants can challenge the adequacy of a fund on various grounds, such as use of the fund for nonlitigation purposes, control of the fund by nonlawyers, or inadequate record keeping. 
groups that spend more on litigation than they receive in fees can easily dedicate fee awards to litigation without diminishing their level of support for nonlitigation programs. ${ }^{173}$ Applying the fee awards to further litigation also superficially promotes the purpose of section 1988, which is "to ensure 'effective access to the judicial process' for persons with civil rights grievances." 174

In addition, litigation funds may lessen the temptation for nonlawyers to exercise control over fee-award money ${ }^{\mathbf{1 7 5}}$ because fee awards will not be available to finance general activities and operating expenses. ${ }^{176}$ If an organization's lay leadership could use fee awards for general expenses, the lay leaders might pressure the organization's attorneys to generate higher fees, or to generate them sooner.

On the other hand, requiring public interest organizations to deposit all fee awards into water-tight litigation funds has some serious drawbacks. First, requiring separate litigation funds will distort incentives to litigate. For some public interest groups, conditioning market rate fees on the maintenance of separate litigation funds will effectively coerce them to apply all fee awards toward more litigation. But litigation is not always the best way for public interest groups to further their goals. Most public interest groups carry on extensive recruiting, fundraising, educational, and lobbying activities that are important companions to litigation. ${ }^{\mathbf{1 7 7}}$ If people

173. For example, if an organization spends $\$ 100,000$ per year on litigation but receives only $\$ 40,000$ per year in attorney fee awards, it should make no difference to the organization whether the $\$ 40,000$ in fees goes into the organization's general treasury or into a separate litigation fund. Either way, the organization will have to spend $\$ 60,000$ out of its other (nonfee) revenues to finance a litigation budget of $\$ 100,000$.

174. Hensley v. Eckerhart, 461 U.S. 424, 429 (1983) (quoting H.R. REP. No. 1558, supra note 132 , at 1).

175. See, e.g., Goodrich v. Department of the Navy, 733 F.2d 1578, 1579 (Fed. Cir. 1984) (separate litigation fund was under sole control of union's General Counsel), cert. denied, 469 U.S. 1189 (1985).

176. This argument is probably flawed because it rests on the premise that nonlawyers in public interest organizations are interested in raising money only for general purposes, not for litigation. That premise is unsound. One would suppose that a nonlawyer would be interested in raising funds for all of an organization's programs, not just for those that could be carried out by nonlawyers.

177. See Boggs, The Role of Public Interest Organizations and the Private Bar in Civil Rights Enforcement in the 1980's, 37 RuTGERs L. Rev. 1065, 1089 (1985) (urging civil rights groups to use "non-litigation models to address civil rights and poverty issues not readily susceptible to direct litigation attack").

Under section 501(c)(3) of the Internal Revenue Code, tax-exempt public interest groups may jeopardize their tax-deductible status if they engage in extensive lobbying. See I.R.C. $\S \S 170(a)(1)$, (c)(2)(D) (West 1987) (providing that charitable donation is tax deductible only if recipient organization "is not disqualified for tax exemption under section 501 (c)(3) by reason of attempting to influence legislation"). However, public interest groups can lobby on a limited basis without jeopardizing their tax-deductible status if they make an election under section $501(\mathrm{~h})$ and abide by its requirements. Moreover, many organizations that engage in public interest litigation are tax exempt under section 501(c)(4), which does not restrict lobbying efforts, rather than sections 501(c)(3) or 501(h), which restrict lobbying. Telephone interview with Ronald Williams, Assistant Branch Chief, Internal Revenue Service Employee Plans and Exempt Organizations Support Services Branch (Jan. 31, 1989) (reporting that most recent available data-from April 1986-show that 27 of 167 tax-exempt organizations engaging in public interest litigation were exempt under section 501 (c)(4) rather than section $501(c)(3))$. Under $N T E U$, however, attorney fees could not be used to finance lobbying efforts. 
are not educated about their rights, they cannot litigate to enforce them; if governments do not respect people's rights, litigation may be inadequate; and if public interest groups lack adequate physical resources (such as space or equipment), litigation may be ineffective. A fee award might therefore be best used for nonlitigation purposes, such as hiring fundraisers, lobbying for new laws, publicizing victories, purchasing computers, or organizing community groups. Fee awards should not be like food stamps, which carry paternalistic restrictions on what can and cannot be purchased, and groups should not suffer the penalty of lower fee awards for spending fees on things they consider more important than litigation. ${ }^{178}$ Section 1988 already gives public interest organizations a strong incentive to pursue litigation because groups can win attorney fees under section 1988 only for litigating-not for lobbying, mediating, organizing, or educating. Rewarding only those groups that apply all fee awards to litigation may make the incentive to litigate stronger than Congress intended.

Conversely, denying market rate fee awards to groups that do not maintain separate litigation funds ${ }^{\mathbf{1 7}}$ would make the incentive to litigate too weak, undercutting the deterrence policy of section 1988. One function of a statutory fee award is to deter defendants from violating constitutional rights in the future by letting them know that defending civil rights violations is expensive. ${ }^{180}$ By making the defense of civil rights violations less expensive, reducing fee awards to cost plus overhead could lower the degree of deterrence. ${ }^{181}$

Requiring separate litigation funds will also complicate the fee-award process. Justice Powell cautioned that fee awards should not generate "a second major litigation," quirement may consume substantial judicial time. If a group has a litigation fund, a court will have to examine the group's books, decide which

178. On the other hand, most groups have litigation budgets that far exceed the amount they receive in fees. My empirical data shows that in $75 \%$ to $80 \%$ of all public interest groups (including most ACLU affiliates), fee awards have accounted for less than one-fourth of their total income over the last five years. For these groups, a separate litigation fund is merely a bookkeeping entry showing that attorney fee awards all go toward further litigation.

179. See supra note 172 (reporting survey data indicating that $55 \%$ of ACLU affiliates and $60 \%$ of other public interest groups do not currently maintain separate litigation funds). These results may overstate the problem because some of the survey respondents may dedicate all of their resources to litigation and thus have no need for a separate litigation fund. But most of the survey respondents apparently engage in many activities other than litigation, and these groups would be denied market rate fees if courts required separate litigation funds.

180. See Davis v. Bolger, 512 F. Supp. 61, 63-64 (D.D.C. 1981).

181. One could argue that separate litigation funds strengthen the deterrence policy of section 1988 by letting all potential defendants know that a public interest group is maintaining a war chest that can be used only for litigation. This argument is weak, however, because the mere ability to finance future litigation is an inadequate deterrent unless the financial resources are backed up by nonlitigation activities such as educating people about their rights and training more lawyers to handle civil rights cases.

182. Hensley v. Eckerhart, 461 U.S. 424,437 (1983). 
expenses relate to "litigation," and monitor future expenditures to ensure that the fees are spent exclusively on litigation. ${ }^{183}$ If a group does not have a separate litigation fund, the court will have to determine the overhead attributable to each victory. ${ }^{184}$

Finally, public interest organizations that devote major efforts to raising funds for litigation may have a strong incentive to interfere with litigation in order to increase fee awards, even if fee awards must be deposited into a separate litigation fund. It is thus difficult to believe that a separate litigation fund will significantly guard against the abuses that the feesharing rule is designed to prevent. ${ }^{185}$

\section{Opinions Going Beyond NTEU}

Despite the policy problems with separate litigation funds, several cases have taken an even more restrictive position than NTEU, holding that market rate fees are inappropriate even if a nonprofit organization does

183. The requirement of separate litigation funds may cause litigants to waste time arguing whether a litigation fund is adequate, verifying that fees are deposited in the litigation fund, and ensuring that fees are put back into the litigative programs that made their recovery possible in the first place. Much of this work will be done by the defendant because the defendant wants to reduce the amount of the fee award. Nevertheless, the court may have to decide various issues, rule on discovery motions, and read briefs on the litigation fund issue. For example, the court may have to decide whether a defendant may look into the books and records of a public interest organization.

184. In NTEU itself, the court remanded for a proper calculation of "the cost to the union of supplying the attorneys' services." 656 F.2d at 849 n.11. To calculate overhead precisely, a court must determine how much the nonprofit group paid for secretarial services, rent, office equipment, depreciation, and other typical components of overhead in connection with the particular case at hand. This is an awesome task. Cf. J. WhIte \& R. Summers, UNIFORM Commercial Code $\$ 7-13$, at 326 (3d ed. 1988) (predicting "bloody battles" over phrase "reasonable overhead" in U.C.C. $\$ 2-708(2)$ because one can expect "no unanimity among accountants about what is overhead and what is not or about how the overhead is to be allocated to the seller's various contracts"). Fortunately, courts have developed a convenient shortcut for calculating overhead; they simply double the amount allocable to the attorney's salary. See, e.g., Sabey v. United States, 6 Cl. Ct. 36, 36 (1984) (awarding fees at salaried hourly rate of union attorney, plus "an equal amount as overhead"); Powell v. Department of the Treasury, 8 M.S.P.B. 21, 29-30 (1981) (explaining rationale for formula). But either party has the right to challenge this formula and to ask courts to calculate actual overhead if it presents "evidence. . . that such an allowance of 100 percent of attorney compensation for professional overhead is substantially excessive or insufficient in the particular case." Powell, 8 M.S.P.B. at 30 (allowing "such variations for individual cases as the evidence may justify"). One court was recently presented with just such a challenge. See Johnson v. United States, 16 Cl. Ct. 321 (1989) (rejecting plaintiffs' challenges to applications of Powell formula in case where union maintained separate litigation fund). The plaintiffs in Johnson unsuccessfully argued: (1) that a staff attorney's gross salary for purposes of the Powell cost-plus-overhead formula should include such fringe benefits as "health, optical, and life insurance; contributions to an employees' pension plan; workers' compensation insurance; FICA; and state unemployment taxes"; and (2) that the hourly rate of a staff attorney should be calculated based on the hours actually worked (excluding vacation and sick days, for example) rather than on the total number of working hours available in the year. $I d$. at 326.

185. See American Association of Law Schools Clinical Section, Report of the Committee on Clinics and Attorney Fees 32 n.66 (1987) (on file with author) (in considering relationship between law school and its clinical programs, there is no reason to believe that law school will have "less interest in collecting fees that can be used for future litigation than in collecting fees that can be used for nonlitigation advocacy"). However, this danger will not rise to the level of a compelling state interest unless there is a showing of actual harm in a particular case. See infra text accompanying notes 324-45. 
channel fees into a separate litigation fund. In Wells v. Schweiker, ${ }^{186}$ for example, a labor union sought fees at market rates and stressed that the fees would be deposited into "a special Legal Representation Fund" used "only for purposes directly related to the legal representation of petitioner's members." 187 The Merit Systems Protection Board considered this to be irrelevant: "[W] hether or not petitioner elects to expend its attorney fee awards solely for litigation-related purposes, the fact remains that the application of the market-value formula to the fee award here would allow petitioner to profit from the underlying activities of its attorneys in this matter." 188 The "profit" would be "commensurate with the extent to which such an award would relieve petitioner of the burden of financing its litigation activities through its general revenue funds." ${ }^{189}$ Accordingly, the Board based fees on cost plus overhead, not market rates. ${ }^{180}$ The Glaims Court reached a similar conclusion in Sabey $v$. United States. ${ }^{191}$

Fortunately for public interest groups, Wells and Sabey were not intended to govern awards in public interest cases. In Sabey, for example, the court emphasized that the fee-award policy of the Fair Labor Standards Act ${ }^{192}$ was unlike the policy of section 1988 because "[r]ather than merely ensuring that employees recover back wages . . . without incurring out-of-pocket expenses, civil rights statutes are intended to actively encourage suits to vindicate fundamental rights." ${ }^{\text {"93 }}$ But this dictum about section 1988 is not very comforting. Defendants in civil rights cases will inevitably argue that a litigation fund not fully funded by fee awards allows an indirect benefit to nonlawyers and does not qualify for market rate awards.

If applied to public interest organizations, cases like Wells and Sabey would cause serious harm. Allowing market rate fees only to those groups wealthy enough to finance all litigation out of a separate litigation fund

186. 12 M.S.P.B. 329 (1982). In Wells, the Merit Systems Protection Board considered the feeaward provision of the Back Pay Act, 5 U.S.C. $§ 5596(\mathrm{~b})(1)(\mathrm{A})(\mathrm{ii})$ (1982).

187. 12 M.S.P.B. at 332 .

188. Id.

189. Id.

190. Id. In Goodrich v. Department of the Navy, 733 F.2d 1578 (Fed. Cir. 1984), cert. denied, 469 U.S. 1189 (1985), the court followed Wells. The union had established a separate litigation fund, under the sole control of the union's General Counsel, that could be used "solely for legal work." Id. at 1579. Nevertheless, the court limited the fee award to the union's expenses in providing the services. Id. at 1580. But the court left open the question "whether a different result might be appropriate if a legal representation fund fully supported the union's legal services program." Id. at 1581. The D.C. Bar rejected Goodrich. See D.C. Comm. on Legal Ethics, Formal Op. 176 (Oct. 21, 1986), reprinted in District of Columbia Bar Legal ETHics Committee Opinions 291, 292 (agreeing with Jordan that market rate fee awards to nonprofit groups maintaining funds devoted exclusively to legal activities are not "shared" with group, and therefore do not violate rule against fee sharing).

191. 6 Cl. Ct. 36, 36 (1984) (where union represented plaintiffs in Fair Labor Standards Act case at no cost as benefit of membership, fee award under Act based on "the hourly salary of plaintiffs' counsel, and an equal amount to cover overhead, is reasonable and appropriate").

192. 29 U.S.C. $\& 216$ (b) (1982).

193. 6 Cl. Ct. at 37 (citing Goodrich, 733 F.2d at 1580). 
would be a cruel irony. Any group whose litigation fund was too small to finance its entire litigation program would be unable to increase the size of the fund through fee awards to its staff attorneys. This rule would especially hurt new groups trying to expand their litigation programs by plowing fee awards back into further litigation. Most new groups would probably not have sufficient litigation funds to cover their entire litigation programs, so under the rationale of Wells and Sabey they would at best be able to break even on litigation even if they won every case. ${ }^{104}$ Since every public interest group loses some cases, the supply of new funds for public interest litigation would inevitably diminish in the long run. ${ }^{195}$

Quite properly, therefore, one court has sharply questioned the rationale of Wells and has indicated that full market rate fee awards are appropriate even if nonprofit groups do not channel fees into separate litigation funds. In Curran v. Department of the Treasury, ${ }^{196}$ a case discussing the fee-award provision of the Back Pay Act, ${ }^{197}$ the court observed:

The Board's assumption that an above-cost fee award will always provide an indirect economic benefit to the non-legal activities of a lay organization is incorrect .... Although an organization may choose to divert its original contribution of general revenues for litigation to support an expansion of its lay activity, it may choose to instead maintain its original contribution and simply add this amount to any fees awarded to the litigation fund as a means of financing greater legal activity. ${ }^{198}$

194. In Devine v. National Treasury Employees Union, 805 F.2d 384 (Fed. Cir. 1986), cert. denied, 108 S. Ct. 67 (1987), a case denying market rate fees under the Equal Access to Justice Act, 28 U.S.C. $\S 2412$ (d) (1982 \& Supp. IV 1986), the court recognized that "[d]ifferent concerns exist when awarding attorney fees in civil rights cases." 805 F.2d at 388 (citing Blum v. Stenson, 465 U.S. 886 (1984)); see also Goodrich, 733 F.2d at 1580-81 (fee-award provision in Back Pay Act is unlike section 1988, because section 1988 fee awards are intended to encourage suits to vindicate civil rights, but there is "no comparable public policy to encourage the bringing of suit by federal employees challenging adverse personnel actions against them"); Powell v. Department of the Treasury, 8 M.S.P.B. 21, 27 n.5 (1981) (rule that fees cannot exceed union's costs "does not encompass" fee awards made under related statute that follows Title VII).

195. Public interest groups could try to make up for the decrease in fee awards by seeking increased charitable donations from the public, but the outlook for raising more funds in this way is not bright. Although donations to public interest groups by individuals increased dramatically during the early years of the Reagan administration, individual contributions were actually lower in 1983 than in 1975. See N. Aron, supra note 4, at 54. More recent data are no more optimistic. See Cox, New Figures Show Growth In Donations Has Slackened, Wall St. J., June 13, 1988, § 2, at 19, col. 5 (reporting results of new study of individual donations). Thus, fee awards are likely to remain an important source of funds for both litigation and nonlitigation activities.

196. 805 F.2d 1406 (9th Cir. 1986). The Curran approach was recently rejected by the Claims Court in Johnson v. United States, 16 Cl. Ct. 321 (1989).

197. 5 U.S.C. $\$ \S 5596(\mathrm{~b})(1)(\mathrm{A})(\mathrm{ii}), 7701$ (g)(1) (1982).

198. 805 F.2d at 1409 n.2 (emphasis in original, citing Wells and Goodrich). In Curran, the court awarded full market rate fees to a union that maintained "a special fund . . . to support the litigation of individual and collective federal employee rights before administrative and judicial tribunals." Id. at 1407. The court agreed that a fund of this kind "satisfies the ethical concerns expressed in NTEU and removes any barrier to the payment of market rates." Id. at 1408 (citations omitted). In reaching this decision, however, the Curran court termed the requirement of separate litigation funds "unprecedented in the arena of ethical standards," $i d$. at $1408 \mathrm{n.1}$, and noted that the government had 
If requiring separate litigation funds is often unwise and unjustified, and if the existing rules of legal ethics do not otherwise permit lawyers to share legal fees with public interest groups, perhaps the bar should create an express exception to the rules that allows lawyers to share legal fees with public interest organizations. I consider that possibility next.

\section{Should the Bar CReate an Exception?}

Rules of professional conduct should be made and revised by the states, not by the federal courts. When the courts strike down existing rules, they leave a vacuum in the existing rules, they cloud remedial rulemaking with dicta, and they tarnish the image of the bar. Unfortunately, the states have often been painfully slow to recognize emerging constitutional trends and to revise their codes of legal ethics to acknowledge these trends. The states fought inch by inch against the rights of public interest organizations and labor unions to solicit cases, employ counsel, and refer cases to attorneys, even though the Supreme Court ruled against the states in case after case on these issues. ${ }^{199}$ The states fought an equally determined battle against the rights of lawyers to advertise through printed media, even though the Supreme Court struck down every state rule it considered that restricted truthful legal advertising in print. ${ }^{200}$

If the anecdotal data and the naked language of the fee-sharing rule are any guide, the states appear equally determined to maintain a strong "wall of separation" between lawyers and nonlawyers with regard to legal

cited "no ethical authority in support of its position," id. at 1409. See also D.C. Comm. on Legal Ethics, Formal Op. 176 (Oct. 21, 1986), reprinted in District of Columbia Bar Legal. Ethics COMMITTEE OPINIONS $291,292 \mathrm{n} .4$ (reserving possibility that market rate fee award might be ethical even "if it were not deposited in a separate legal assistance fund").

199. See In re Primus, 436 U.S. 412, 434-35 (1978) (absent proof of undue influence, overreaching, misrepresentation, or invasion of privacy, state may not discipline lawyer for sending unsolicited letter on behalf of ACLU offering free legal representation to potential plaintiff); United Transp. Union v. State Bar, 401 U.S. 576, 585 (1971) (state cannot constitutionally enjoin labor union's practice of recommending particular lawyers to its injured members, limiting fees that could be charged by those lawyers, transporting members to lawyers' offices, and requiring lawyers to reimburse union for transportation expenses); United Mine Workers v. Illinois State Bar Ass'n, 389 U.S. 217, 221-22 (1967) (labor union has First Amendment right to hire attorney on salary basis to serve members); Brotherhood of R.R. Trainmen v. Virginia ex rel. Virginia State Bar, 377 U.S. 1, 8 (1964) (First Amendment protects right of union to recommend specific lawyers to its injured members); NAACP v. Button, 371 U.S. 415,417 (1963) (unconstitutional for state to make it unlawful for organization to recommend particular attorneys to conduct litigation in which organization has no pecuniary right or liability).

200. See Shapero v. Kentucky State Bar Ass'n, 108 S. Ct. 1916 (1988) (striking down state ethical rule prohibiting truthful targeted mail solicitation to people known to need legal services); Zauderer $v$. Office of Disciplinary Counsel, 471 U.S. 626 (1985) (striking down state rule prohibiting lawyers from placing truthful newspaper advertisements soliciting plaintiffs and offering legal advice regarding particular legal problems); In re R.M.J., 455 U.S. 191 (1982) (striking down complete ban on truthful written advertisements using language not approved by state courts); Bates v. State Bar, 433 U.S. 350 (1977) (striking down state rule prohibiting truthful newspaper advertising of prices by lawyers soliciting employment for routine legal services). The only case in which the Supreme Court upheld a state rule in the area of advertising and solicitation is Ohralik v. Ohio State Bar Ass'n, 436 U.S. 447 (1978) (state may prohibit lawyers from soliciting clients in person, for pecuniary gain, under circumstance likely to pose dangers of improper conduct). 
fees. ${ }^{201}$ But the states should not cling blindly to tradition on the matter of fee sharing. Rather, the states should carefully reexamine the fee-sharing rule to determine whether an exception is wise, and what that exception should provide. In undertaking this reexamination, the bar should keep in mind the risk that if the bar does not voluntarily create an exception that allows fee sharing with public interest groups, the courts may force them to do so. ${ }^{202}$ In deciding whether to allow lawyers to share legal fees with public interest groups, the bar should compare the state interests in enforcing the present blanket prohibition against fee sharing to the public interests in permitting the unfettered use of fee awards by public interest groups.

\section{A. The State's Interests: The Seven Deadly Sins}

The prohibition against fee sharing is intended to guard against seven "deadly sins": (1) stirring up litigation; (2) improper methods of solicitation; (3) the unauthorized practice of law; (4) excessive fees; (5) referrals to incompetent lawyers; (6) unethical litigation practices; and (7) injurious lay interference with the attorney-client relationship. ${ }^{203}$ These justifications for the fee-sharing prohibition grew up almost entirely in the commercial sphere, and most of them are inapplicable or highly speculative in the context of public interest litigation. Moreover, every one of the state's interests is already protected by other rules and statutes.

\section{Eliminating Incentives for Nonlawyers to Stir Up Litigation}

In the state's view, nonlawyers who share legal fees have an incentive to solicit plaintiffs for cases, and thus stir up litigation that might otherwise remain dormant. By preventing this, states can relieve pressure on court dockets and preserve social harmony. ${ }^{204}$ In the context of nonprofit public interest litigation, however, the state's interest in preventing nonlawyers

201. In addition to the fee-sharing prohibition per se, see MODEL RuLEs, supra note 5, Rule 5.4(b) (providing that lawyer "shall not form a partnership with a nonlawyer if any of the activities of the partnership consist of the practice of law"); MODEL CODE, supra note 5, DR 3-103(A) (substantially identical).

202. Professor Hazard has suggested that the rigid rule against fee sharing may be unconstitutional even as applied to commercial lawyers in profit-making law firms as an "irrational regulation of business." See Hazard \& Hodes, The LAw OF LAWYering, supra note 65, at 472. A constitutional analysis of the fee-sharing rule in the for-profit context is beyond the scope of this Article, but the policy analysis of allowing fee sharing with public interest organizations, see infra text accompanying notes 203-59, suggests that the states should allow some fee sharing with nonlawyers in the commercial arena. This was certainly the view of the Kutak Commission. See supra note 64 (quoting Kutak Commission proposal).

203. This list draws on the numerous cases and ethical opinions cited earlier in this Article. See supra text accompanying notes 25-82. I should note that lawyers are fully capable of committing all of these sins themselves, but since lawyers are trained in legal ethics and are officers of the court, the rule against fee sharing with nonlawyers is focused primarily on the potential wickedness of nonlawyers.

204. See Bates v. State Bar, 433 U.S. 350, 375-76 (1977) (discussing "societal repose"). 
from fomenting litigation or soliciting plaintiffs carries no weight. As the Court noted in NAACP v. Button, ${ }^{205}$ a public interest law suit is a form of political expression to be encouraged, not an evil to be prevented. ${ }^{208}$ Accordingly, the Court held that the NAACP had a First Amendment right to solicit plaintiffs to file school desegregation suits. ${ }^{20 z}$ Since Button, the Court has made clear that both lawyers and nonlawyers have a constitutional right to solicit cases on behalf of nonprofit public interest organizations, provided that the solicitors do not stand to reap any personal financial benefit from the solicitation. ${ }^{208}$

\section{Preventing Improper Methods of Solicitation by Nonlawyers}

The state does retain a strong interest in prohibiting abusive methods of solicitation, such as false or misleading statements, undue influence, or invasion of privacy. ${ }^{209}$ From the state's perspective, even public interest groups might be tempted to use these improper methods of solicitation if cases could result in fee awards that would benefit the organizations. This view is logical. Public interest groups already have a strong ideological interest in soliciting plaintiffs by whatever means necessary. The additional incentives of a share of the legal fees will undeniably increase this incentive. However, the state already prohibits false or misleading communications about legal services, ${ }^{\mathbf{2 1 0}}$ and the Supreme Court has indicated that states can directly prohibit public interest groups from using improper methods of solicitation. ${ }^{211}$ These existing protections appear to be effective, for there is no evidence that existing fee-sharing agreements with public interest organizations are causing the organizations to engage in improper methods of solicitation. ${ }^{\mathbf{2 1 2}}$ Thus, the state's interest in using the

205. 371 U.S. 415 (1963).

206. See id. at 429-30, 440. The dissent agreed, stating: "We have passed the point where litigation is regarded as an evil that must be avoided if some accommodation short of a lawsuit can possibly be worked out." Id. at 453 (Harlan, J., dissenting); see also In re Primus, 436 U.S. 412, 436-37 (1978) (fear of " 'stirring up' of frivolous or vexatious litigation" does not justify violation of First Amendment rights); Bates v. State Bar, 433 U.S. 350, $376 \mathrm{n} .32$ (1977) ("It would be difficult to understand [Button and the other group legal services cases] if a lawsuit were somehow viewed as an evil in itself.").

207. Button, 371 U.S. at $429-30$.

208. See In re Primus, 436 U.S. 412, 422-32 (1978); United Transp. Union v. State Bar, 401 U.S. 576, 585 (1971); United Mine Workers v. Illinois State Bar Ass'n, 389 U.S. 217, 221-25 (1967); Brotherhood of R.R. Trainmen v. Virginia ex rel. Virginia State Bar, 377 U.S. 1, 5-8 (1964).

209. See In re Primus, 436 U.S. 412, 432 (1978) (not disputing "importance" of state's interests in preventing solicitation that employs undue influence, overreaching, misrepresentation, and invasion of privacy).

210. See Model Rules, supra note 5, Rule 7.1(a).

211. See In re Primus, 436 U.S. 412,438 (1978) (state may proscribe solicitation by lawyers that is "misleading, overbearing, or involves other features of deception or improper influence" (footnote omitted)).

212. The lack of evidence may be more significant than usual because the enemies of public interest organizations would probably be quick to publicize any alleged improprieties. On the other hand, the lack of evidence may indicate the extreme difficulty of policing personal solicitation. $C f$. Ohralik v. Ohio State Bar Ass'n, 436 U.S. 447, 466 (1978) ("[I]n-person solicitation is not visible or 
fee-sharing rule to curb improper solicitation seems to be speculative and weak. $^{213}$

\section{Preventing Unauthorized Practice of Law}

In theory, a nonlawyer sharing in legal fees has an incentive to engage in the unauthorized practice of law. ${ }^{\mathbf{2 1 4}}$ For example, a nonlawyer might handle legal matters personally rather than turning away business when a lawyer is not available, or might give legal advice to a plaintiff to influence the plaintiff's decisions about the case in a way that would maximize legal fees for the nonlawyer, possibly at the expense of the plaintiff's best interests. These concerns have some logical force. A public interest group in immediate need of funds might be tempted to send lay representatives to persuade a plaintiff to settle (so that the plaintiff could petition for fees), ${ }^{215}$ and a public interest group intent on maximizing fees over the long run might advise a plaintiff to reject a settlement offer and go to trial, thus increasing the total fee award if the plaintiff prevails.

It is very difficult to learn whether any abuses of this type are actually happening. If they are, however, the states already combat them by enforcing existing statutes prohibiting the unauthorized practice of law, ${ }^{\mathbf{2 1 6}}$ and by enforcing ethical rules that make lawyers responsible for the conduct of nonlawyer associates ${ }^{217}$ and prohibit lawyers from assisting nonlawyers in the unauthorized practice of law. ${ }^{218} \mathrm{~A}$ broad prophylactic response to a speculative danger, in the form of a blanket ban against fee sharing with all nonlawyers and nonlawyer groups, seems unwarranted.

\section{Preventing Excessive Fees}

In the commercial arena, the states have historically argued that fee sharing with nonlawyers leads to excessive legal fees because a client is paying both a nonlawyer and a lawyer, rather than just a lawyer. ${ }^{219}$ In

otherwise open to public scrutiny. Often there is no witness other than the lawyer and the layperson whom he has solicited, rendering it difficult or impossible to obtain reliable proof of what actually took place.").

213. In Button, the state presented evidence suggesting that some school segregation plaintiffs had been improperly lured into litigation by the NAACP. See 371 U.S. at 422 n.6. The Court, however, faulted the plaintiffs for their ignorance and found the NAACP to be blameless. Id.

214. The Model Code provides that "[s]ince a lawyer should not aid or encourage a layman to practice law, [a layman] should not practice law in association with a layman or otherwise share legal fees with a layman." MODEL CODE, supra note 5, EC 3-8.

215. It is important to keep in mind that a plaintiff is entitled to fees even if she prevails through settlement rather than by winning at trial. See Maher v. Gagne, 448 U.S. 122, 129 (1980) ("The fact that respondent prevailed through a settlement rather than through litigation does not weaken her claim to fees.").

216. See Rhode, supra note 37.

217. See MODEL RuLEs, supra note 5, Rule 5.3(c) (setting forth circumstances in which lawyers are responsible for violations of rules by nonlawyers).

218. See id. Rule 5.5(b) (prohibiting lawyers from assisting nonlawyers in "activity that constitutes the unauthorized practice of law").

219. See, e.g., Alpers v. Hunt, 86 Cal. 78, 88, 24 P. 846, 849 (1890); Emmons, Williams, Mires 
addition, overbearing lay solicitation might discourage comparison shopping for lawyers, thus preventing people from searching for the lowest fee. ${ }^{220}$ Even in the for-profit setting, such theories are questionable, especially now that advertising by lawyers permits potential clients to compare fees with relative ease. In public interest litigation, these theories are completely inapplicable because fees are paid by the losing party, not by the client, and are either negotiated at arms length or awarded after judicial review. ${ }^{221}$ The amount of the fee award will be the same whether it is paid to the lawyer alone or to the lawyer and a nonlawyer together. ${ }^{222}$

In any event, the states already guard against excessive fees in other ways. The disciplinary rules prohibit lawyers from charging excessive fees, ${ }^{223}$ and the fee-award statutes themselves expressly mandate that fee awards be "reasonable."224 Given the meticulous case-by-case review of statutory fee awards, ${ }^{225}$ this protection seems more than adequate and the fee-sharing rule seems entirely unnecessary.

\section{Preventing Referrals to Incompetent Lawyers}

Allowing nonlawyers to share fees could encourage nonlawyers to refer cases to those lawyers willing to share the highest percentage of their fees

\& Leech v. State Bar, 6 Cal. App. 3d 565, 574-75, 86 Cal. Rptr. 367, 373 (1970); New York State Bar Ass'n Comm. on Professional Ethics, Formal Op. 572 (June 5, 1985), reprinted in [1986-2 Transfer Binder] Nat'l Rep. on Legal Ethics \& Prof. Resp. (UPA) NY:OPINIONS:31.

220. This argument depends on the questionable assumption that fee sharing leads nonlawyers to apply undue influence to cajole clients into signing retainers. See supra text accompanying notes 209-13.

221. See In re Primus, 436 U.S. 412, 429-30 (1978) (noting "differences between counsel fees awarded by a court and traditional fee-paying arrangements"). If the parties are unable to negotiate the amount of a fee award, the amount is set by a court based on the adversarial submissions of the parties. See, e.g., Greater Los Angeles Council on Deafness v. Community Television, 813 F.2d 217, 221 (9th Gir. 1987); NAACP v. City of Evergreen, 812 F.2d 1332, 1334 (11th Cir. 1987).

222. The state does have an interest in preventing organizations from encouraging their lawyers to run up fees by spending unnecessary time on a case, but the state can enforce this interest by prohibiting unnecessary litigation tactics at the outset, by refusing to pay excessive fees in settlement, or by persuading the court to deny unreasonable fees, as section 1988 requires the court to do. These methods of combatting excessive fees are narrower and more precise than the blanket ban on fee sharing with nonlawyers.

One might even argue that fee sharing with public interest groups results in lower fees rather than higher ones. Once a lawyer has agreed to turn over all fees to the organization, the lawyer loses all financial interest in the fee award and only the organization retains an interest. Because of its nonprofit and tax-exempt status, and because nonlawyers are ordinarily willing to work for less money than lawyers, the organization may be content with a lower fee than the lawyer personally would accept.

223. See, e.g., MODEL Rules, supra note 5, Rule 1.5(a) ("A lawyer's fee shall be reasonable."); MODEL CODE, supra note 5, DR 2-106(A) ("A lawyer shall not enter into an agreement for, charge, or collect an illegal or clearly excessive fee.").

224. See, e.g., 42 U.S.C. $§ 1988$ (1982) (allowing court to award "reasonable" fee to prevailing party in civil rights litigation); id. $\S 2000 \mathrm{e}-5(\mathrm{k})$ (allowing court to award "reasonable" fee to prevailing party in employment discrimination litigation).

225. See, e.g., Hensley v. Eckerhart, 461 U.S. 424, 435-36 (1983) (requiring courts to deny fees for work unrelated to successful claims); Jean v. Nelson, 863 F.2d 759, 769-80 (11th Cir. 1988) (scrutinizing fee award under Equal Access to Justice Act and remanding for new calculation); Lawrence v. City of Philadelphia, 700 F. Supp. 832, 835-36 (E.D. Pa. 1988) (reviewing fee petition and denying part of fee request). 
rather than to those best qualified to handle cases. ${ }^{228}$ If Attorney $A$ will share a higher percentage of fees than Attorney $B$, then nonlawyers will have an incentive to refer cases to Attorney $A$ even if Attorney $A$ is not competent, or even if Attorney B is more competent. ${ }^{227}$

But this fear makes little sense in the statutory award context because there are no fees to share unless the attorney prevails. Groups therefore have a strong financial incentive to select the most competent attorneys in order to maximize fees. In addition, public interest groups have an ideological incentive to choose attorneys who will win cases and set favorable precedents. And as a practical matter, most groups require attorneys to share a fixed amount of the fee; they do not negotiate on a case-by-case basis to see which attorney will share the highest percentage. ${ }^{228}$ The concern about referrals to incompetent attorneys is therefore very weak.

In any case, Rule $7.2(\mathrm{c})$ already prohibits lawyers from paying more than the "usual charges" to obtain cases from public interest groups, ${ }^{229}$ and Rule 1.1 requires lawyers to handle matters competently. ${ }^{230}$

\section{Preventing Unethical Practices in Litigation}

The bar believes that nonlawyers, who are not bound by professional standards and are under the jurisdiction neither of the bar nor of the courts, might resort to unethical practices to win cases in which they have a contingent share. ${ }^{231}$ For example, a nonlawyer whose income depends on winning a case might bribe a witness or juror, create false evidence, destroy evidence, or engage in other unethical practices-or might urge a

226. This argument is independent of the argument that fee-sharing agreements would cause nonlawyers to use improper methods of solicitation. Bankers, realtors, accountants, and many other nonlawyers who do not actively solicit cases are frequently asked to recommend lawyers.

227. This undesirable practice has occurred for decades in the personal injury field. See Philadelphia Report, supra note 49, at 9 ("A large number of Philadelphia physicians make it a practice of referring accident cases to lawyers in return for a commission . . . on a percentage basis.").

228. In my empirical survey, only a handful of organizations reported negotiating fee agreements on a case-by-case basis, and those groups indicated that they were willing to share a higher percentage of the fee when necessary either to attract more competent lawyers, or to compensate lawyers for taking on risky cases unlikely to yield any fees. Perhaps some attorneys refuse to work on cases for public interest organizations that require fee sharing, and in that sense organizations may be referring cases to less competent attorneys than if they did not require fee sharing. But this is not the evil that the rule is intended to prevent. By analogy, private law firms might be able to hire more competent attorneys if they offered higher salaries or more favorable partnership terms, but a refusal to do so does not violate the rules of legal ethics.

229. See MODEL Rules, supra note 5, Rule 7.2(c); supra text accompanying notes 90-110 (discussing rule and its Code counterpart).

230. See MODEl Rules, supra note 5, Rule 1.1 ("A lawyer shall provide competent representation to a client.").

231. This fear is also reflected in other rules, such as the common prohibition against paying contingent fees to expert witnesses. See MODEL RULES, supra note 5, Rule 3.4(b) (lawyer shall not "offer an inducement to a witness that is prohibited by law"); id. Rule 3.4(b) comment (noting "common law rule in most jurisdictions . . that it is improper to pay an expert witness a contingent fee"). 
lawyer to do so. ${ }^{232}$ The state unquestionably has a strong interest in preventing these abusive practices.

In the context of public interest litigation, however, there is no evidence of these abusive practices. ${ }^{233}$ Even though most public interest organizations do currently share in fee awards, ${ }^{234}$ public interest organizations and their lawyers are seldom the target of sanctions for unethical litigation practices. ${ }^{235}$ This is especially significant given the novelty of many cases sponsored by public interest groups and the hostility that many defendants must feel for those who solicit and sponsor litigation against them. Apparently, because of their high visibility, their desire for charitable donations, their limited financial resources, their basic integrity, and their dedication to the rule of law, public interest groups and their lawyers pay especially careful attention to ethical obligations. The interest in using the feesharing rule to prevent unethical litigation practices therefore seems weak.

In any event, the existing protections against unethical litigation practices are abundant. The rules of legal ethics, ${ }^{236}$ the Federal Rules of Civil Procedure, ${ }^{237}$ inherent judicial power, ${ }^{238}$ and state substantive laws against fraud, perjury, and other evils already prohibit the unsavory conduct at which the fee-sharing rule is aimed.

\section{Protecting the Attorney-Client Relationship}

The foremost purpose of the rule against fee sharing is "to protect the lawyer's professional independence of judgment," protecting the attorney-client relationship from injurious lay interference. ${ }^{240}$ The state's argument is that fee-sharing agreements give public

232. For historical examples of litigation fraud perpetrated by nonlawyers who shared in legal fees, see Philadelphia Report, supra note 49, at 40-46 (discussing false medical testimony and repair bills).

233. This is not to say that public interest lawyers are never sanctioned. There are some recent examples of improper litigation conduct by lawyers for public interest groups. See, e.g., Bell v. Lynaugh, 858 F.2d 978, 981-83 (5th Cir. 1988) (rebuking law school's Capital Punishment Clinic for abusing writ of habeas corpus by repeatedly filing last minute appeals). But the fact that such sanctions are rare suggests that fee-sharing arrangements do not lead to improprieties often enough to warrant a prophylactic rule prohibiting all fee sharing with public interest organizations.

234. See supra text accompanying notes 17-20 (discussing empirical data).

235. See generally American Bar Association Section of Littigation, Sanctions: Rule 11 AND OTHER Powers (2d ed. 1988) (collecting numerous cases).

236. See, e.g., MOdel Rules, supra note 5, Rule 3.1 (prohibiting frivolous claims and defenses); id. Rule 3.2 (prohibiting unjustified delay); id. Rule 3.3(a) (prohibiting false evidence); id. Rule 3.4 (requiring fairness to opposing parties and counsel).

237. See, e.g., FED. R. Crv. P. 11, 26(g), 37 (prohibiting unreasonable pleadings, motions, and discovery tactics).

238. See Link v. Wabash R.R., 370 U.S. 626, 630-32 (1962) (discussing inherent judicial power to sanction litigation abuse).

239. MODEl Rules, supra note 5, Rule 5.4 comment. The title of the rule is "Professional Independence of a Lawyer." See also Button, 371 U.S. at 460 (Harlan, J., dissenting) (challenged law reflects state's deep desire "to prevent any interference with the uniquely personal relationship between lawyer and client").

240. The bedrock of the attorney-client relationship is loyalty-"the lawyer's virtually total loyalty to the client and the client's interests." C. Wolfram, MOdERN Legal ETHICs $\$ 4.1$, at 146 
interest groups an incentive to interfere with the independent judgment of the lawyers. Specifically, fee-sharing agreements give organizations an incentive to maximize attorney fees, even if this harms client interests. For example, an organization might urge a lawyer to oppose a favorable settlement if a trial would be likely to result in a higher fee award. ${ }^{241}$ Conversely, an organization might encourage the lawyer to recommend that a client accept an inadequate settlement if the terms include generous attorney fees. ${ }^{242}$ An organization might also discourage an attorney from spending adequate time on cases unlikely to yield fee awards. ${ }^{243}$

For staff attorneys, the dangers of lay interference are inherent. As Justice Harlan explained in his dissenting opinion in Button: "When an attorney is employed by an association or corporation to represent individual litigants . . . the lawyer necessarily finds himself with a divided allegiance-to his employer and to his client-which may prevent full compliance with his basic professional obligations." 244 The question is whether this danger of divided allegiance is serious enough to warrant a total prohibition on fee sharing between lawyers and public interest organizations.

In the abstract, the degree of danger depends on two factors. First, how great is the organization's incentive to interfere with the attorney-client relationship? Second, how much leverage does the organization have over its attorneys? The mix of incentive and leverage varies depending on whether the attorney handling a case is a cooperating attorney or a staff attorney.

In the case of cooperating attorneys, fee-sharing agreements do not present a serious danger to the attorney-client relationship. An organization's

(1986). To fulfill the duty of loyalty, attorneys must exercise professional judgment solely in the best interests of their clients, avoiding conflicts not only with other current clients, but also with former clients, third parties, and the lawyers' own personal and financial interests. See Model RuLEs, supra note 5, Rule 1.7 \& comment ("Loyalty is an essential element in the lawyer's relationship to a client.").

241. Occasionally, fees are available for monitoring a consent decree, or for other post-settlement work. But in most cases a settlement ends all billing on a case.

242. A court can disapprove a negotiated fee agreement if it has judicial power to review the agreement, but the court has such review power only in class actions and other special cases. See FED. R. CIv. P. 23(e) ("A class action shall not be dismissed or compromised without the approval of the court . . . ."); R. Marcus \& E. Sherman, Complex Litigation 469 (1985) ("[U]nlike almost all other settlements, class action settlements are subject to substantive review by the court."). Courts have no power to review settlements in cases brought by individuals, even if a settlement may substantially affect the public interest. See FED. R. Crv. P. 41(a) (giving plaintiffs automatic right to dismiss any action-except class action, action where receiver has been appointed, or action where dismissal is governed by federal statute-simply by filing stipulation of dismissal signed by all parties to action).

243. Cf. Florida Bar v. Consolidated Business and Legal Forms, Inc., 386 So. 2d 797, 798-99 (Fla. 1980) (finding for-profit corporation violated ethical rules by limiting time salaried lawyers could spend on flat-fee cases).

244. 371 U.S. at 460 (Harlan, J., dissenting) (emphasis added). Justice Harlan saw the potential for serious conflicts between individual clients and the NAACP. For example, the NAACP prohibited its branches from sponsoring "equal facility cases," and insisted on pressing for a full and immediate end to segregation in every case, but an individual litigant might have preferred to negotiate with the school board rather than see the schools closed for years due to litigation. See id. at $448-50,462$. 
incentive to exercise control is reduced to the extent that a cooperating attorney will keep part of the fee award. If an organization will share only half of a fee award, it has only half the financial incentive to interfere with the attorney's handling of the case. Moreover, a cooperating attorney is not on the organization's payroll, and thus has no fear of losing a job for failing to follow the organization's wishes. The cooperating attorney also has her own offices, clients, and support staff independent of the organization. Moreover, the short supply of cooperating attorneys ${ }^{245}$ gives them the upper hand in any disagreements with groups, especially in controversial or high-risk cases. Thus, an organization's leverage over a cooperating attorney is relatively small.

In the case of staff attorneys, by comparison, fee-sharing agreements present a more serious danger of organizational control. Most staff attorneys depend on their employers for all of their income, their clients, their office space, and their support services. They may thus be vulnerable to an organization's efforts to control litigation. This distinguishes contemporary public interest litigation from the litigation in Button, In re Primus, ${ }^{248}$ United Transportation Union v. State Bar, ${ }^{247}$ United Mine Workers v. Illinois State Bar Association, ${ }^{248}$ and Brotherhood of Railroad Trainmen $v$. Virginia ex rel. Virginia State Bar, ${ }^{249}$ none of which involved full time staff attorneys. ${ }^{250}$ Moreover, because a staff attorney is part of the organization, enriching the organization through fee awards indirectly enriches the staff attorney as well. ${ }^{251}$

The state's argument, however, is entirely hypothetical. As my survey indicates, virtually every public interest organization that employs staff attorneys already demands that its staff attorneys turn over all courtawarded fees. Yet while there is some recent evidence that fee-sharing agreements have led to harmful lay control over litigation in the private

245. See N. ARON, supra note 4, at 80-82 (between 1975 and 1985, firms began to cut back their pro bono work). Ms. Aron identifies four possible reasons for this cutback: (1) higher operating costs and greater competition for private firms have caused pressure to increase billable hours; (2) firms often reject public interest cases that might offend paying clients; (3) firms prefer pro bono matters that can be disposed of quickly, so they avoid public interest cases, which often involve extensive factfinding and litigation; and (4) public interest cases often require specialized knowledge and skills that lawyers in private firms do not possess. Id. at 81.

Because of the difficulty of finding cooperating attorneys who were willing to work without any possibility of obtaining fees, the ACLU began in 1977 to allow state affiliates to share statutory fee awards with cooperating attorneys. See In re Primus, 436 U.S. 412, 430 n.24 (1978). As a member of the Legal Steering Committee for the ACLU affiliate in St. Louis, the author also knows from personal experience that the ACLU is frequently unable to sponsor meritorious cases because cooperating attorneys cannot be located to handle them.

246. 436 U.S. 412 (1978).

247. 401 U.S. 576 (1971).

248. 389 U.S. 217 (1967)

249. 377 U.S. 1 (1964).

250. See infra text accompanying notes 270-316.

251. For example, a staff attorney's working conditions, job security, and future salary level depend heavily on the employing organization's financial condition. 
sector, ${ }^{252}$ there is little evidence that fee-sharing agreements lead to similar abuses in the public interest context. ${ }^{263}$ Absent reports either of disciplinary actions against staff attorneys. or of state efforts to penalize public interest organizations for attempting to control litigation, it seems unreasonable to suppose a danger of harm to the attorney-client relationship great enough to warrant a total prohibition on fee sharing between lawyers and public interest groups.

Even if organizations would like to control their staff attorneys, the rules of legal ethics already provide multiple protections against lay interference with an attorney's independent judgment. For example, Rule 1.2(a) requires a lawyer to "abide by a client's decisions concerning the objectives of representation," and more specifically to "abide by a client's decision whether to accept an offer of settlement of a matter."254 This rule prohibits a lawyer from allowing an organization to control decisions about settlement. In addition, Rule 1.7 prohibits a lawyer from representing a client if the representation "may be materially limited by the lawyer's responsibilities . . . to a third person,"

Other rules address the situation of staff lawyers even more directly. Rule 1.8(f), for example, prohibits lawyers from accepting compensation from anyone other than a client unless the third party does not interfere with "the lawyer's independence of professional judgment or with the client-lawyer relationship." ${ }^{\text {"256 }}$ Rule 5.4(c) reiterates the protections of Rule $1.8(f)$ by providing that a lawyer "shall not permit a person who recom-

252. In Florida Bar v. Consolidated Business and Legal Forms, Inc., 386 So. 2d 797 (Fla. 1980), for example, a corporation owned by nonlawyers hired lawyers to provide third parties with legal services such as uncontested divorces, wills, and personal bankruptcies. Clients paid all fees directly to the corporation, and the corporation paid the lawyers a salary plus a percentage of gross fees. The nonlawyers exercised control over the legal services by limiting client conference time per case, prescribing the forms the lawyers could use, and setting fees. See id. at 798-99. The state demonstrated that these practices had resulted in harm to particular clients. See id. at 800 .

253. One well-known scholar has argued that the NAACP has placed its own ideological quest for racial balance in the schools over the desire of many of its clients for educational improvement. See Bell, Serving Two Masters: Integration Ideals and Client Interests in School Desegregation Litigation, 85 YALE L.J. 470, 471 (1976) (asking whether philosophical complexities of school desegregation litigation justify "more diligent oversight of the lawyer-client relationship by the bench and bar"). However, Professor Bell does not discuss fee-sharing arrangements. Moreover, Professor Bell indicates only that some groups of clients within the school desegregation cases had different goals than the NAACP, not that the NAACP was able to control the litigation over the objections of all clients. See id. at 482-87.

254. MOdel Rutes, supra note 5, Rule 1.2(a).

255. Id. Rule 1.7. This Rule does allow a lawyer to represent a client despite conflicting interests if the lawyer reasonably believes that the representation will not be adversely affected and the client consents after being fully informed of the circumstances. Id.

256. Id. Rule 1.8(f). The lawyer's obligation to protect confidential information is set out in Rule 1.6 , the essence of which prohibits a lawyer from disclosing client confidences unless the client consents or unless disclosure is necessary to "prevent the client from committing a criminal act that the lawyer believes is likely to result in imminent death or substantial bodily harm." Id. Rule 1.6. The obligation of Rule $1.8(\mathrm{f})$ to maintain client confidences means that the lawyer cannot reveal client confidences to the third party who is paying the fees unless the client consents. Even then, the lawyer has an obligation to ensure that the third party abides by Rule 1.6, whether or not the third party is a lawyer. 
mends, employs, or pays the lawyer to render legal services for another to direct or regulate the lawyer's professional judgment in rendering such legal services." ${ }^{257}$ Rules $1.8(\mathrm{f})$ and $5.4(\mathrm{c})$ should be viewed as a recognition that lawyers can be trusted to resist directions from nonlawyers who employ them to serve others. Otherwise, these rules would be an empty aspiration. Staff lawyers for public interest organizations can be trusted to follow this rule as ably as associates for private law firms, who are likewise employed and paid to render legal services for others. ${ }^{258}$

In sum, the rule against fee sharing is largely redundant. Even if there were no rule against fee sharing, the rules of legal ethics would still prohibit lawyers from allowing third parties to compromise independent professional judgment, and the state could use these rules to prevent actual or potential harm. The rules thus already adequately protect the attorneyclient relationship against injurious lay interference. As the Kutak Commission recognized, the state can already satisfy its interests by directly enforcing existing statutes, ethical rules, and rules of procedure without imposing a blanket ban on fee sharing between lawyers and nonlawyers. ${ }^{280}$

\section{B. Countervailing Interests: The Value of Public Interest Groups}

Even if the dangers of fee sharing were greater, and other protections for the state's interest were somehow insufficient, there still would be substantial reasons for allowing lawyers to share legal fees with public interest organizations. In my view, public interest organizations are the unique and indispensable vehicle through which citizens can systematically sponsor and assist litigation advancing broad public interests. Without the expertise and focusing efforts of public interest groups, individual sponsorship of litigation brought by others would be highly impractical. Individuals acting alone, without the medium of an association, would be unable to locate litigants, evaluate cases, find lawyers, or finance the expenses of major litigation, much less to organize a sustained long-term agenda for coordinating litigation ${ }^{260}$ and working in harmony with likeminded citizens. ${ }^{261}$

257. Id. Rule 5.4(c).

258. The client pays the bills, but the law firm pays the associate's salary. In a struggle between the law firm and the client for the associate's time and attention, the law firm seemingly has as least as much leverage over an associate as a public interest organization has over a staff attorney.

259. See Hazard \& Hodes, The Law of Lawyering, supra note 65, at 469-72 (arguing that ABA's adoption of current rule against fee sharing was motivated by "illegitimate rationale, namely economic protectionism").

260. See generally, M. Tushnet, The NAACP's Legal Strategy Against Segregated EdUCATION 13-20 (1987) (describing formulation of plan for comprehensive legal strategy).

261. In addition to coordinating their own cases to avoid duplication of efforts, many public interest groups coordinate litigation with other public interest groups having similar goals. See O'Connor \& Epstein, supra note 17, at 489,500 ("liberal" public interest groups have "tended to reinforce each other's litigation efforts through coordination, either in the form of co-sponsored briefs or amicus 
Moreover, public interest groups serve the administration of justice by extending legal assistance to individuals who would otherwise be ignorant of their rights, unable to find a lawyer, or without the financial ability to undertake litigation on their own behalf.

Finally, public interest groups serve the judicial system and our entire system of government by focusing litigation on key issues according to a coherent plan. Using the courts as a complement to the legislative process ${ }^{262}$ public interest organizations serve as the political parties of the judicial system. ${ }^{263}$ They enable people to band together in support of litigation to further common goals that are beyond the reach of individuals acting alone and that have not provoked an adequate response in the majoritarian process of the legislature. ${ }^{264}$ Like political parties in the legislative arena, public interest litigation groups focus and distill the broad range of their members' individual interests into positions that will result in the greatest good for the greatest number.

In my opinion, the blanket prohibition on fee sharing between lawyers and public interest groups overestimates the dangers of fee sharing and undervalues the importance of those groups to society. If the states reevaluate their longstanding historical reasons for the rule against fee sharing, they should conclude that those reasons do not support a prohibi-

briefs filed in support of the sponsoring party," and "conservative" public interest groups also "generally share a similar outlook and thus can coordinate their efforts" (footnotes omitted)). In some areas, there are informal networks of organizations that "talk to each other frequently and divide up the work.' "N. ARON, supra note 4, at 99 (quoting Judith Lichtman of Women's Legal Defense Fund).

262. Public interest groups also devote substantial resources to work at the administrative level, monitoring and seeking to influence the actions of government agencies that are relatively immune from the majoritarian political process. See N. ARON, supra note 4, at 95 ("monitoring the activities of the federal administrative agencies remains a significant part of the work" of public interest groups). Bolstered by judicial opinions forcing agencies to allow a greater voice for public interest groups in administrative decisionmaking, public interest activities at the administrative level have been so vigorous that they have in many ways transformed the way in which administrative agencies operate. See Stewart, The Reformation of American Administrative Law, 88 Harv. L. REv. 1667, 1711-16 (1975) (explaining transformation of administrative agencies into forum for broad spectrum of interest groups).

263. See Comment, The Role of the Judiciary in the Confrontation with the Problems of Environmental Quality, 17 UCLA L. REv. 1070, 1098-99 (1970) (arguing that environmental litigation sponsored by public interest groups has expanded boundaries of standing and thus "enables the individual citizen to cast $a$ different kind of vote" (emphasis added)). Public interest lawyers also appear to see public interest litigation as a highly political endeavor. Public interest lawyers at both ends of the political spectrum identify strongly with a political party. Lawyers in "liberal" public interest groups overwhelmingly vote for presidential candidates from the Democratic Party. See Lichter \& Rothman, What Interests the Public and What Interests the Public Interests, PUB. OPINION, April-May 1983, at 44, 46 table 2 (tabulating survey results indicating that since 1968, no Republican presidential candidate has received more than $4 \%$ of votes of public interest group leaders). Similarly, lawyers in "conservative" public interest litigation groups tend to be active in the Republican Party. See O'Connor \& Epstein, supra note 17, at 493-501 (recounting key roles played by prominent Republicans such as Ed Meese, James Watt, Kit Bond, and various close Reagan advisors in rise of "conservative public interest law firms").

264. In our system of separated powers and judicial review, "it is not uncommon for legislators to believe that constitutional questions are none of their business at all." Brest, Who Decides?, $58 \mathrm{~S}$. CaL. L. Rev. 661, 670 (1985). Consequently, representative bodies often do not adequately protect constitutional rights, especially the constitutional rights of minorities. See generally D. MoRGAN, Congress And the Constitution: A Study of Responsibility (1966). 
tion against fee sharing in the new and different context of organized public interest litigation.

But policy arguments are an uncertain basis for amending the feesharing rule, because those who write the rules of ethics may not value public interest groups, or public interest litigation, as highly as I do. Some writers have attacked public interest groups for taking positions in litigation antithetical to the public at large ${ }^{265}$ and insensitive to the interests of the individual clients they sponsor. ${ }^{268}$ Others have attacked public interest groups for inviting courts to supplant the legislature and to undermine our system of representative, majoritarian government. ${ }^{267}$ If the leaders of the bar share these negative views about public interest litigation, then they will not support an amendment to the fee-sharing rule that allows public interest organizations to use legal services, in effect, as a fundraising device. If these negative views of public interest litigation prevail, the bar is unlikely to amend the fee-sharing rule unless the Constitution requires that the states allow lawyers to share fees with public interest organizations. I therefore turn to constitutional considerations.

\section{Do Lawyers Have a First Amendment Right to Share Market Rate Fees with Public Interest Organizations?}

At the outset of this constitutional analysis, I want to assert two important premises. The first premise is that constitutional rights of public interest organizations and the lawyers who work with them are reciprocal. When the Supreme Court extended First Amendment protection to public interest organizations, it extended the same protection to their staff and cooperating attorneys. ${ }^{288}$ Thus, if lawyers have a First Amendment right to enter into fee-sharing contracts with public interest organizations, then public interest organizations have an equal and reciprocal right to condi-

265. See Lichter \& Rothman, supra note 263, at 48 (reporting survey results suggesting that public interest lawyers "often deviate from the outlook and perspectives of the general public"). Those who believe that public interest groups do not truly represent the public have consequently formed competing litigation organizations. See generally Houck, With Charity for All, 93 YALE L.J. 1415, 1454-1514 (1984) (discussing growth and variety of "business public interest law firms").

266. Bell, supra note 253 , at $479-80$ (court orders mandating racial balance may be educationally disadvantageous, yet "civil rights lawyers continue to argue that black children are entitled to integrated schools without regard to the educational effects of such assignments"). But see Correspondence, 86 YALE L.J. 378, 381 (1976) (letter from Nathaniel Jones, then General Counsel to NAACP Special Contribution Fund, arguing that "Professor Bell's allegation that civil rights lawyers do not ethically represent the interests of the black community can scarcely stand").

267. See Rabkin, Public Interest Law: Is It Law in the "Public Interest"?, 8 Harv. J.L. \& PuB. PoL'y 341, 344 (1985) (arguing that courts are inappropriately being made into "fora for a pluralist dialogue at the behest of public interest firms").

268. This has been true even when the attorneys have derived personal financial benefit from the association's referrals. See Brotherhood of R.R. Trainmen v. Virginia ex rel. Virginia State Bar, 377 U.S. 1, 5 \& n.9 (1964) (protecting rights of attorneys to accept cases union solicited for them even though attorneys received reasonable contingent fee for handling cases); NAACP v. Button, 371 U.S. $415,420-21$ (1963) (protecting rights of NAACP staff attorneys to solicit cases even though they were paid $\$ 60$ per day for working on NAACP-sponsored cases). 
tion employment or referrals on such contracts. This reciprocity of rights is entirely logical. Attorneys could not freely associate with public interest organizations if the organizations could be prosecuted for working with them, and an organization's rights to supply attorneys for public interest litigation would be empty if attorneys could be disciplined for working on cases sponsored by the organizations.

The second premise is that the First Amendment rights of nonprofit public interest organizations are at least as great as the First Amendment rights of other nonprofit organizations. Although labor unions and other nonprofit groups may be very different from public interest organizations in purpose and composition, the Supreme Gourt has treated them equally when discussing First Amendment rights regarding litigation. ${ }^{269}$ This equal treatment is proper. The reasons for protecting First Amendment rights of labor unions, charities, and other nonprofit groups apply with equal force to the special genre of nonprofit groups known as public interest organizations. If the Court has bestowed a First Amendment right on a nonprofit labor union or charity, therefore, the same right extends to the public interest organizations that are the subject of this Article. Against the backdrop of these important premises, we can analyze the constitutionality of the fee-sharing rule.

\section{A. The First Amendment and Group Legal Services}

Superficially, fee sharing appears to fall outside the scope of First Amendment protection. Fee sharing is not literally "speech" and is unlike the kinds of expressive activities the First Amendment has ordinarily protected. One could argue that fee sharing is mere "conduct," which the First Amendment does not protect. This argument is weakened, however, by a line of Supreme Court cases over the past twenty-five years directly addressing group legal services. In these cases, the Court generally rejected the speech/conduct distinction and extended First Amendment protection far beyond traditional forms of speech, petition, assembly, and association. Most pertinent here, the group legal services cases accorded First Amendment protection to several financial arrangements between lawyers and public interest groups.

The seminal case about group legal services, $N A A C P$ v. Button, ${ }^{270}$ was the first case to extend First Amendment protection to a financial relationship between lawyers and a public interest group. In Button, the NAACP

269. See United Mine Workers v. Illinois State Bar Ass'n, 389 U.S. 217, 222 (1967) (noting that NAACP v. Button, 371 U.S. 415 (1963), and Brotherhood of R.R. Trainmen v. Virginia ex rel. Virginia State Bar, 377 U.S. 1 (1964), alike dealt with "the right of an association to provide legal services for its members"); Trainmen, 377 U.S. at 8 (asserting that union's activities "fall just as clearly within the protection of the First Amendment" as the NAACP's, and that "the Constitution protects the associational rights of the members of the union precisely as it does those of the NAACP").

270. 371 U.S. 415 (1963). 
challenged a Virginia statute that prohibited any group from financing litigation or recommending attorneys for litigation in which the group was not a party and had no pecuniary interest. ${ }^{271}$ The issue was not simply whether the NAACP had a First Amendment right to recommend attorneys, but whether it had the right to recommend attorneys on the NAACP's own payroll. ${ }^{272}$ Virginia argued that it could prohibit the NAACP from recommending attorneys in its own employ, because the NAACP's financial leverage over its staff attorneys gave the NAACP too much control over the litigation. ${ }^{273}$ The state urged that the statute was needed to insure high professional standards, and thus fell "within the traditional purview of state regulation of professional conduct."274

The Supreme Court disagreed. For the NAACP, the Court said, litigation was "not a technique of resolving private differences," but rather "a form of political expression."273 Without stopping to distinguish among or define the contours of various First Amendment rights, the Court held that the NAAGP's sponsorship of litigation fell within the scope of First Amendment protection for speech, freedom of association, and the right to petition government for the redress of grievances. ${ }^{276}$ Accordingly, the First Amendment protected the NAAGP's "entire arrangement"-including its financial sponsorship of cases, its direct solicitation of plaintiffs, its recommendation of its staff attorneys, and its payment of those attorneys. ${ }^{277}$

The Button case involved the rights of a group to sponsor constitutional litigation. The next step for group legal services was to extend the protections of Button to federal statutory litigation having no constitutional

271. This statute prohibited the NAACP from financing and providing attorneys for school desegregation suits. See id. at $419-26$.

272. At oral argument, the Court asked the NAACP's attorney, Robert Carter (now a federal judge), whether the NAACP advised potential plaintiffs that it would not finance litigation "unless they go to NAACP [staff] lawyers." Mr. Carter replied: "[T] hat's exactly what the case would reduce itself to, your Honor." Tr. of Oral Arg. at 11 (reargument). At another point in the oral argument, one of the Justices (not identified by name) said:

As far as I'm concerned, you should argue . . . that the NAACP, for the purpose of protecting and asserting the constitutional rights of Negroes in the courts, through lawyers, for that reason set up an arrangement under which your organization and its Fund hired lawyers at special rates. Your case has to stand on the basis that you do recommend those lawyers, and that the statute which restricts you from doing so either is or is not a violation of constitutional rights. As far as I'm concerned, I see no other way to decide this case.

Id. at 18-19 (emphasis added).

In later cases, the Supreme Court stressed that the NAACP's staff attorneys were "actually employed by the association which recommended them," Brotherhood of R.R. Trainmen v. Virginia ex rel. Virginia State Bar, 377 U.S. 1, 7 (1964), or were "actually paid by the association," United Mine Workers v. Illinois State Bar Ass'n, 389 U.S. 217, 221 (1967), or were " organized as a staff and paid by' that organization," In re Primus, 436 U.S. 412,429 (1978) (quoting Button, 371 U.S. at 434).

273. Tr. of Oral Arg. at 27, Button (No. 62-5) (reargument). Virginia argued that NAACP staff attorneys had to "keep on the good side of the chairman" or they would not be reelected to the NAACP's legal staff the following year. Id.

274. Button, 371 U.S. at 438.

275. Id. at 429.

276. Id. at $429-30$.

277. Id. at 442 (emphasis added). 
overtones. The Court took this large step, over a vehement dissent, in Brotherhood of Railroad Trainmen v. Virginia ex rel. Virginia State $B a r .{ }^{278}$ The case involved a solicitation and referral plan designed to protect injured railroad workers against greedy and incompetent lawyers. Under the plan, the union maintained a legal department that investigated railway accidents and recommended that injured union members retain a lawyer the union had selected based on competence and experience. Lower courts had repeatedly outlawed various versions of this plan, ${ }^{279}$ but the Supreme Court gave the plan constitutional protection. Again fusing (and perhaps confusing) various First Amendment rights, the Court held that "the First Amendment's guarantees of free speech, petition and assembly give railroad workers the right to gather together for the lawful purpose of helping and advising one another in asserting the rights Congress gave them."280

The Court soon invoked Button and Trainmen to protect a union's right to hire a staff attorney to serve union members free of charge. In United Mine Workers v. Illinois State Bar Association, ${ }^{281}$ the only issue was whether the union could "hire attorneys on a salary basis to assist its members in the assertion of their legal rights." ${ }^{\text {"282 }}$ The state court had held that the union could not employ an attorney to serve its members, because "any 'financial connection of any kind" " between the union and the attorneys was illegal. ${ }^{283}$ The Supreme Court reversed. The record did not show that the financial connection between the union and the staff had harmed clients, the profession, or the public. ${ }^{284}$ Moreover, by flatly prohibiting any financial connection between attorneys and the union, the state court's decree would have prohibited even the arrangements already approved in Button and Trainmen. The Court therefore struck down the decree on First Amendment grounds. ${ }^{285}$

Financial connections were again at issue in United Transportation Union v. State Bar, ${ }^{286}$ another case challenging the trainmen's plan. ${ }^{287}$ The union demanded that the attorneys it recommended agree to charge no more than twenty-five percent of any recovery, and to reimburse union

278. 377 U.S. 1 (1964).

279. See, e.g., In re O'Neill, 5 F. Supp. 465 (E.D.N.Y. 1933); In re Brotherhood of R.R. Trainmen, 13 Ill. 2d 391, 150 N.E.2d 163 (1958). Only one court had ever upheld the plan. See Ryan v. Pennsylvania R.R., 268 Ill. App. 364 (1932).

280. Trainmen, 377 U.S. at 5.

281. 389 U.S. 217 (1967).

282. Id. at 222 (emphasis added). The Court's opinion was "limited to this one aspect of the Union's activities." Id. at 218 n.1.

283. Id. at 225 (quoting 35 Ill. 2 d 112, 118, 219 N.E.2d 503, 506 (1966)) (emphasis added).

284. Id.

285. The Court held that the First Amendment guarantees of speech, assembly, and petition gave the union this right. Id. at 222 .

286. 401 U.S. 576 (1971).

287. The case was originally filed against the Brotherhood of Railroad Trainmen, but in 1969 the Brotherhood merged into the newly created United Transportation Union. See id. at 577 \& n.1. 
representatives for transporting injured workers to the attorneys' offices. ${ }^{288}$ Although neither practice directly involved speech or political expression, the Court rejected the state's challenges to both practices. In the context of the union's overall plan, the Court held that transporting injured workers was protected by the union members' First Amendment right to "help and advise each other in securing effective legal representation." ${ }^{288}$ Limiting contingent fees, similarly, was part of the First Amendment right "to act collectively to obtain affordable and effective legal representation."280

A contingent financial relationship between a lawyer and a public interest organization was examined by the Court in In re Primus, ${ }^{291}$ the most recent case in the Button line. In Primus, the state disciplined a lawyer for soliciting a case on behalf of the ACLU, which stood to make a "profit" by requesting attorney fees if the plaintiff prevailed. ${ }^{292}$ The Supreme Court held that this possible financial benefit to the ACLU was an inadequate basis for discipline and did not take the ACLU out of the protection of Button. ${ }^{293}$ On the contrary, the Court viewed the possible benefit to the ACLU as a virtue because it meant that the attorney herself had no financial interest in the case. Specifically, the Court emphasized that "even if there had been an award during the period in question, it would have gone to the central fund of the ACLU,"284 and that "any award of counsel fees would have been received only for the organization's benefit," ${ }^{285}$ not for the benefit of the attorney personally. ${ }^{286}$ Because the

288. See id. at 577-78. The Court discussed some other alleged practices as well, but either gave them less prominence or disposed of the allegations without reaching the merits.

289. Id. at 582. The Court stated:

The Union conceded that . . . Union representatives were reimbursed [by the attorneys] for their actual time spent and out-of-pocket expenses incurred in bringing injured members or their families to the offices of the legal counsel. Since the members of a union have a First Amendment right to help and advise each other in securing effective legal representation, there can be no doubt that transportation of injured members to an attorney's office is within the scope of that protected activity.

Id. (emphasis added).

290. Id. at 584 (citing United Mine Workers). Justice Harlan's separate opinion in United Transportation Union criticized the majority for extending First Amendment protection to a mere economic arrangement-to nothing more than "a combination of purchasers of services seeking to increase their market power." Id. at 599 (Harlan, J., concurring in part and dissenting in part). To Harlan, the relationship of this plan to First Amendment interests was "remote at best." Id.

291. 436 U.S. 412 (1978).

292. Id. at $418-20$ \& n.10.

293. Id. at 429 .

294. Id. at 430 (footnote omitted). The footnote quoted the ACLU's policy that cooperating attorneys could never personally receive any payment for rendering legal services in cases sponsored by the ACLU. See also Record at 188, In re Smith, 268 S.C. 259, 233 S.E.2d 301 (1977), rev. sub nom. In re Primus, 436 U.S. 412 (1978) (transcript of Ms. Primus's disciplinary hearing) (quoting undisputed testimony that attorney fee award "goes into the organization and not to the attorney"). In 1977, after the solicitation in Primus occurred, the ACLU changed this policy so that local affiliates could, if they wished, allow cooperating attorneys to keep part of the fees. See Primus, 436 U.S. at 430 n.24.

295. 436 U.S. at 428 n.21 (discipline was based "solely on the possibility that appellant's solicitation might have conferred a financial benefit on the ACLU").

296. See id. at 428-29 ("It is conceded that appellant received no compensation for any of the 
disciplined attorney was motivated by ideology and not by pecuniary gain, her solicitation fell squarely within her right to engage in political expression and association through litigation. ${ }^{292}$

Read together, the group legal services cases from Button through Primus establish First Amendment protection for financial arrangements between lawyers and public interest organizations whenever those arrangements are integral to an organization's purposes. ${ }^{288}$ If fee-sharing agreements are integral to the litigation programs of public interest groups-and my survey suggests that they are-then fee-sharing arrangements fall within the protection of the First Amendment. In United Mine Workers, the Court warned against "indirect restraints" on freedom of expression that did not prohibit speech, petition, or assembly "as such."298 The blanket prohibition on fee sharing is the kind of indirect restraint that could infringe on First Amendment rights by impeding the association of attorneys and public interest organizations for purposes of litigation.

Nevertheless, the Supreme Court has never expressly extended First Amendment protection to fee-sharing arrangements with nonprofit groups. On the contrary, the Court has repeatedly refused to decide whether fee-sharing agreements fall within the First Amendment's scope. In Trainmen, for example, the dissent attacked the union for sharing legal fees, noting that the union had for many years required regional counsel to share twenty-five percent of their fees with the union. ${ }^{300}$ The decree below had enjoined the union from sharing fees with recommended lawyers and from permitting fee sharing with its nonlawyer investigators, but the majority did not reach the fee-sharing issue because the union had agreed to comply with the injunction against fee sharing. ${ }^{301}$ In United Transportation Union, the lower court had enjoined the union from "sharing in any manner in the legal fees of any lawyer or countenancing the splitting of or sharing in such fees with any layman or lay agency,"302

activities in question."). The state conjectured that Ms. Primus might enhance her reputation through her ACLU work, and thus generate increased foundation support for her own work, but even the state court had found no evidence that Ms. Primus acted on her own behalf. See id. at $428 \mathrm{n} .21$ (citing lower court opinion).

297. See id. at 428-32 \& n.24 (because Ms. Primus was not motivated by personal gain, her letter of solicitation fell "within the generous zone of First Amendment protection reserved for associational freedoms").

298. See generally L. TRIBE, American Constitutional Law $\$ 12-26$, at 1015-16 (2d ed. 1988) (defining "integral activity" as any activity-specifically including litigation or referrals by nonprofit groups-"integral to the association in the sense that the association's protected purposes would be significantly frustrated were the activity disallowed").

299. 389 U.S. at 222. Justice Harlan urged the Court to distinguish expression from conduct, see id. at 225-34 (Harlan, J., dissenting), stating in particular that "litigation is more than speech; it is conduct," $i d$. at 226 , but the majority again rejected the invitation.

300. See 377 U.S. at 9, 11.

301. See id. at 5 n.9.

302. 401 U.S. at 579 n.4. 
and the dissent would have upheld this provision of the decree. ${ }^{303}$ The majority did not argue that fee sharing was protected by the First Amendment, but pointed out that the record contained "not a line of evidence" concerning fee sharing. ${ }^{304}$

The case that comes closest to protecting fee-sharing arrangements is Primus, in which the ACLU was to receive any attorney fees awarded in the underlying case. ${ }^{305}$ But for several reasons, the Primus case cannot be read as a blanket endorsement of all fee-sharing arrangements between lawyers and public interest groups. First, the conduct at issue in Primus occurred before Congress passed section $1988 .^{306}$ Under pre-section 1988 law, the ACLU itself would have applied for and received any fee award directly. $^{307}$ The attorney handling the litigation would neither have received the fee award personally nor formally assigned it to the organization, and thus would not have "shared" fees with the organization. Consequently, the situation in Primus did not involve fee sharing per se, the state did not charge Ms. Primus with violating the fee-sharing rule, and the Court never mentioned the rule against sharing fees with nonlawyers. ${ }^{308}$

Second, the attorney who handled the case solicited by Ms. Primus was not a full-time staff attorney. He was either a part-time staff attorney or an unsalaried cooperating attorney (the record is unclear on this point), ${ }^{309}$ and in either case had income and clients independent of the ACLU. This is significant. A public interest group has little leverage over an attorney with an independent livelihood, especially one who will not personally receive any fees even if the client prevails.

Third, Primus expressly refused to decide whether its decision might have been different if the ACLU had been sharing fees with its cooperating attorneys. ${ }^{310 ~ " W e ~ a r e ~ n o t ~ p r e s e n t e d ~ i n ~ t h i s ~ c a s e, " ~ t h e ~ C o u r t ~ o b s e r v e d, ~}$

303. Id. at 598 (Harlan, J., concurring in part and dissenting in part).

304. Id. at 583 .

305. See 436 U.S. at 430 (noting that any fee award "would have gone to the central fund of the ACLU").

306. The solicitation letter that formed the "centerpiece" of the litigation was dated August 30, 1973. See id. at 416 \& n.6.

307. See, e.g., Torres v. Sachs, 69 F.R.D. 343 (S.D.N.Y. 1975), affd, 538 F.2d 10 (2d Cir. 1976) (discussing fee awards to groups before passage of section 1988); see also supra text accompanying notes 114-32 (same).

308. It is important to note that neither Ms. Primus nor the attorney who actually handled the case on the ACLU's behalf was charged with violating the rule against sharing fees with a nonlawyer. Rather, she was charged only with improper solicitation, including solicitation on behalf of a group that would benefit financially from the solicited suit. See Primus, 436 U.S. at 417-21.

309. See id. at 415 n.3 (describing Ms. Primus and her associate Carlton Bagby as "unsalaried cooperating attorneys," and her associate Herbert Buhl as "staff counsel" for ACLU); Walker v. Pierce, 560 F.2d 609, 610 (4th Cir. 1977) (listing Carlton Bagby as counsel of record on appeal), cert. denied, 434 U.S. 1075 (1978).

310. 436 U.S. at 430 n.24. The Court noted that the ACLU had historically insisted on keeping all fees for itself to guard against the possibility that cooperating attorneys would accept only those cases likely to produce fees. In 1977, however, the ACLU changed policies, permitting affiliates to experiment by allowing cooperating attorneys to retain part of the fees. The South Carolina ACLU 
"with a situation where the income of the lawyer who solicits the prospective litigant or who engages in the actual representation of the solicited client rises or falls with the outcome of the particular litigation." 311 Thus, even if Primus implies First Amendment protection for a cooperating attorney's agreement to share all fees with a public interest group, it might not protect a cooperating attorney's agreement to share only part of a fee award. The abstract logic of Primus should protect partial fee sharing, but there is one plausible distinction. A cooperating attorney becomes vulnerable to losing income-and thus more subject to an organization's control-to the extent she will be sharing in any fee award.

Finally, the Primus case did not address the situation of the full-time staff attorney who has agreed to turn over all court-awarded fees to the organization. Primus, therefore, does not definitively establish comprehensive First Amendment protection for fee-sharing arrangements with public interest groups.

To determine whether the First Amendment protects fee sharing with public interest groups, we need to undertake two inquiries. First, we need to examine more carefully the policies underlying the First Amendment rights articulated in the group legal services cases from Button through Primus. Second, if the policies indicate that fee sharing is protected by the First Amendment, we need to apply the standard that the state must meet in order to justify an infringement on First Amendment rights. Should the infringement prove unjustified, it should convince the bar, the legislatures, and the courts to reexamine the present restrictions on fee sharing with public interest groups.

\section{B. Policies Underlying the Group Legal Services Cases}

The group legal services cases express two related policies. One policy is to assist nonprofit organizations in their efforts to extend "low-cost, effective legal representation" to individual litigants. ${ }^{312}$ As the Court said in United Transportation Union, the "common thread" running through the group legal services cases is that "collective activity undertaken to obtain meaningful access to the courts is a fundamental right within the protection of the First Amendment," hollow promise if courts could deny associations of workers or others the means of enabling their members to meet the costs of legal representa-

chapter had not adopted any such fee-sharing arrangement, so the new policy did not come into play in Primus. The Court therefore was careful to "express no opinion whether our analysis in this case would be different had the latter policy been in effect during the period in question." Id.

311. Id. at 436 n.30 (citing id. at 428-31 \& n.24) (emphasis added). The italicized language indicates that the Court had in mind lawyers whose incomes would rise if they successfully represented clients solicited by others. That dictum would encompass lawyers who agree to share only part of any court-awarded fees with nonprofit groups in cases solicited by the groups.

312. Id. at 426 (citing Trainmen, United Mine Workers, and United Transportation Union).

313. 401 U.S. at 585. 
tion." ${ }^{314}$ A second policy of the group legal services cases is to foster political expression by minority groups. The cases express the Court's belief that associating to sponsor litigation is often "the most effective form of political association" for minorities, ${ }^{315}$ and may even be "the sole practicable avenue open to a minority to petition for redress of grievances." ${ }^{316}$ Fee-sharing arrangements further both policies.

\section{Low-Cost Legal Services}

Fee-sharing agreements help to extend low-cost legal representation to all citizens by helping public interest groups generate funds. The more money an organization has to hire staff attorneys, to recruit and train cooperating attorneys, and to finance the expenses of litigation, the more cases the organization can handle or supervise. Since public interest organizations do not charge clients for legal services, ${ }^{317}$ fee-sharing agreements help people obtain low-cost legal representation. The bar has long recognized that fee-sharing agreements are an appropriate way of financing lawyer referral services, ${ }^{\mathbf{3 1 8}}$ and they are an equally appropriate vehicle for financing public interest groups.

One could arguably distinguish fee sharing on the grounds that agreements to share market rate fees will raise the cost of legal services to the defendants paying the fees. ${ }^{319}$ If fee-sharing agreements are allowed, defendants who do not prevail in public interest cases will pay market fees rather than only the actual cost of legal services. ${ }^{320}$ And the lure of market

314. Id. at 585-86 (emphasis added). The Court added that this "was the holding in United Mine Workers, Trainmen, and NAACP v. Button." Id. at 586. The phrase "or others" and the citation to Button make clear that the holding was not confined to labor unions.

315. Button, 371 U.S. at 431.

316. Id. at 430 . Sometimes the interests of the members and the interests of the individual litigants are essentially congruent. In Button, for example, the Court took the position that the aims and interests of the NAACP were not in conflict with the interests of the litigants for whom the NAACP provided attorneys and financing. See id. at 443.

317. Public interest law firms often do charge for their services, but the states have not questioned fee-sharing agreements within public interest law firms.

318. See supra text accompanying notes 96-104.

319. Moreover, defendants may attempt to pass these costs along to the public. When a governmental defendant is ordered to pay fees to a prevailing plaintiff, or when the government has agreed to pay a fee award, the taxpayers bear the cost of the award directly because the government's money comes from taxes and fees of some kind. Even if taxes are not increased to pay the award, other governmental services may be cut back, making legal fees a relatively higher portion of the government's budget. When a private employer is ordered to pay fees to a prevailing plaintiff, the employer will attempt to pass on the cost of a fee award to consumers. However, a private company can pass along the cost to consumers only if the demand for the company's products or services is inelastic. A company that cannot pass along the costs may become less profitable, and the shareholders will ultimately bear the cost of the fee award.

320. Fees based on market rates appear to be nearly double the amount of fees based solely on cost plus overhead. See, e.g., Goodrich v. Department of the Navy, 733 F.2d 1578 (Fed. Cir. 1984) (awarding only $\$ 1958.64$ based on cost plus overhead, rather than $\$ 3675$ requested by attorney based on market rate), cert. denied, 469 U.S. 1189 (1985); Sabey v. United States, 6 Cl. Ct. 36 (1984) (awarding only $\$ 38$ per hour based on cost plus overhead, rather than $\$ 75$ per hour request based on market rate). 
rate fees will result in more cases, increasing defense costs still further. ${ }^{\mathbf{3 2 1}}$ But this line of argument distorts the group legal services cases. The group legal services cases allow associations to lower the cost of providing competent lawyers to individuals, not to entities such as railroads or school boards. As long as fee-sharing agreements help individual litigants meet the cost of legal services and obtain meaningful access to the courts, the cost of defending against public interest lawsuits is constitutionally irrelevant. ${ }^{322}$

\section{Political Expression for Minorities}

Fee-sharing agreements also facilitate political expression by minorities. According to the Court's jurisprudence in the group legal services cases, the First Amendment rights to petition for a redress of grievances, to assemble peaceably, and to engage in free speech, "though not identical, are inseparable." ${ }^{\prime 323}$ Fee-sharing arrangements assist public interest organizations in carrying out their right to associate (that is, to assemble) for the purpose of litigation (that is, petitioning the government for redress of grievances), and this litigation is a form of political expression (that is, free speech). Without the right to share legal fees, the resources for engaging in political expression through organized litigation programs would be far more limited. The Court's group legal services cases were intended to expand, not limit, public interest litigation.

I conclude that fee-sharing agreements between lawyers and public interest groups directly serve the policies that have led the Court to extend First Amendment protection to a variety of financial arrangements between lawyers and public interest groups. The only remaining inquiry is whether the state can advance countervailing interests to justify a restriction on First Amendment liberties.

321. In addition, defense costs may increase because the greater incentive of market rate fees will encourage plaintiff' attorneys to spend more hours on each case in which a plaintiff is likely to prevail.

322. The conclusion that higher defense costs are irrelevant to a First Amendment analysis seems inescapable because defense costs increase whenever plaintiffs obtain greater access to the courts. Whether the defense costs increase because plaintiffs bring more suits or because each individual suit is more expensive, or both, has never concerned the Supreme Court in First Amendment cases.

323. United Mine Workers, 389 U.S. at 222 (quoting Thomas v. Collins, 323 U.S. 516, 530 (1945)). Because of this inseparability, the group legal services cases discuss First Amendment rights in many different permutations and combinations, as if they were interconnected or interchangeable. In Button, for example, the Court referred at various times to the First Amendment rights of "expression and association," "advocacy," "political expression," "petitioning for the redress of grievances," "orderly group activity," "the right "to engage in association for the advancement of beliefs and ideas," " and "association for litigation." 371 U.S. at 428-31. Sometimes, the Court melded various rights together into a unified whole. See supra text accompanying notes 276 \& 280. 


\section{The Constitutional Test}

To overcome the First Amendment right to share legal fees with public interest organizations, the state must satisfy the stringent First Amendment test applied in the context of political speech. ${ }^{\mathbf{3 2 4}}$ This test has two independent components. First, the state must advance a compelling reason for any significant infringement on First Amendment rights. ${ }^{325}$ Second, even if the state can articulate a compelling interest, it must still regulate with precision, ${ }^{328}$ using regulatory measures that directly advance the state's interests ${ }^{327}$ and that restrict First Amendment freedoms as little as possible. ${ }^{328}$

Applying this two-pronged test to the fee-sharing rule is relatively easy. As we have seen, the state's interests in avoiding excessive fees is a non sequitur in the context of public interest litigation, ${ }^{329}$ and its interest in preventing nonlawyers from stirring up litigation is constitutionally irrelevant. ${ }^{330}$ The state's interests in preventing abusive methods of solicitation, unauthorized practice, improper referrals, and unethical litigation practices are potentially compelling but wholly speculative because there is no evidence that fee-sharing agreements are causing any of these evils. ${ }^{331}$ In

324. The rational basis or "reasonable relationship" test does not apply if an activity has First Amendment protection. For that reason, the Court rejected the reasonable relationship test in Button. Justice Harlan, believing that litigation was primarily conduct rather than speech, favored a test under which a regulation "not directly suppressing speech or peaceable assembly, but having some impact on the form or manner of their exercise will be sustained if the regulation has a reasonable relationship to a proper governmental objective and does not unduly interfere with such individual rights." Button, 371 U.S. at 454 (Harlan, J., dissenting) (emphasis added). The majority, however, considered the reasonable relationship test too weak to protect First Amendment liberties. Id. at 438.

325. See, e.g., Button, 371 U.S. at 438 ("The decisions of this Court have consistently held that only a compelling state interest . . . can justify limiting First Amendment freedoms.").

326. See, e.g., id. at 438 ("[p]recision of regulation must be the touchstone" in First Amendment area).

327. See, e.g., Village of Schaumburg v. Citizens for a Better Env't, 444 U.S. 620, 636-39 (1980) (striking down municipal ordinance because it only "peripherally promoted" and was "insufficiently related" to substantial state interests at which law was supposedly aimed).

328. See, e.g., Shelton v. Tucker, 364 U.S. 479, 488 (1960) ("The breadth of legislative abridgment must be viewed in the light of less drastic means for achieving the same basic purpose." (footnote omitted)). See generally J. Nowak, R. Rotunda \& J. Young, Constitutional. Law \& 16.10, at 848 (3d ed. 1986) (even when law is intended to further substantial government interest, Court "requires that the legislation use means which are the "least restrictive' of free speech"). First Amendment doctrine also allows a plaintiff to attack a regulation under the "overbreadth" doctrine if the regulation may substantially impinge anyone's First Amendment rights, even if it would be constitutional as applied to the plaintiff. See, e.g., Broadrick v. Oklahoma, 413 U.S. 601, 611-16 (1973) (explaining rationale for doctrine); Gooding v. Wilson, 405 U.S. 518, 521 (1972) ("TT] the transcendent value to all society of constitutionally protected expression is deemed to justify allowing attacks on overly broad statutes with no requirement that the person making the attack demonstrate that his own conduct could not be regulated by a statute drawn with the requisite narrow specificity." (citation omitted)); Button, 371 U.S. at 432 (law may be invalid "if it prohibits privileged exercises of First Amendment rights whether or not ... the petitioner has engaged in privileged conduct").

329. See supra text accompanying notes $219-25$.

330. See supra text accompanying notes 204-08.

331. See supra text accompanying notes 209-13 (discussing abusive methods of solicitation), 214-18 (discussing unauthorized practice), 226-30 (discussing improper referrals) \& 231-38 (discussing unethical litigation practices). 
any event, the state could attack every one of these evils through far less restrictive measures than a blanket ban on fee sharing between lawyers and public interest groups. ${ }^{332}$

The only interest of any real consequence underlying the fee-sharing prohibition is the state's interest in protecting the attorney-client relationship against interference by nonlawyers. Although I have already discussed the attorney-client relationship from the standpoint of policy, ${ }^{333}$ the importance and complexity of this interest makes it worth revisiting from a constitutional perspective.

\section{Compelling State Interests}

In all of the group legal services cases, the Supreme Court has made clear that public interest organizations may not control litigation or cause serious conflicts for their attorneys. ${ }^{34}$ In Button, for example, the Court struck down Virginia's statute partly because the state had made "no showing of a serious danger . . . of professionally reprehensible conflicts of interest which rules against solicitation frequently seek to prevent."335 Conversely, the state's interest apparently would have been compelling if the record had permitted "an inference of any injurious intervention in or control of litigation." 336

This focus on conflicts or control continued in United Mine Workers ${ }^{\mathbf{3 3 7}}$ and Primus. Generally, the Court insists on a showing of actual harm before a state can take action that abridges First Amendment rights, ${ }^{338}$ but

332. See supra text accompanying notes 211-12 (abusive solicitation), 216-18 (unauthorized practice), 223-25 (excessive fees), 229-30 (improper referrals) \& 236-38 (unethical litigation practices).

333. See supra text accompanying notes 239-59.

334. This premise deserves serious reexamination, for it is built on a conception of the attorneyclient relationship that may not be well suited to public interest litigation. One could argue, for example, that a public interest organization's decision not to settle a case should take precedence over the client's views. This would be contrary to the current rules of legal ethics, which provide that lawyers "shall abide by a client's decision whether to accept an offer of settlement of a matter." MODEL Rules, supra note 5, Rule 1.2(a). But giving precedence to the organization's views would ensure that the narrow, parochial interests of an individual client would not override the public interest in establishing an important precedent or bringing facts to light through the public forum of the courtroom. Cf. Fiss, Against Settlement, 93 YALE L.J. 1073, 1085 (1984) ("Parties might settle while leaving justice undone."). This Article is not the proper place to explore this argument fully, but I am working on a separate piece examining the attorney-client relationship in public interest litigation.

335. 371 U.S. at 443.

336. Id. at 444. Justice White's separate opinion in Button also condemned the control of litigation by nonlawyer organizations. Had Virginia's law proscribed only "the actual day-to-day management and dictation of the tactics, strategy, and conduct of litigation by a lay entity such as the NAACP," Justice White would have voted to uphold it. Id. at 447 (White, J., concurring in part and dissenting in part). In his mind, "neither the practice of law by such an organization nor its management of the litigation of its members or others is constitutionally protected." Id.

337. See 389 U.S. at 224 (finding "no indication that the theoretically imaginable divergence between the interests of union and member ever actually arose in the context of a particular lawsuit").

338. See Primus, 436 U.S. at 434 (showing of potential danger may suffice to infringe First Amendment rights in context of commercial affairs, but attorneys exercising protected freedoms of association and expression may not be disciplined unless their conduct "in fact involved the type of misconduct" at which regulation is aimed); Ohralik v. Ohio State Bar Ass'n, 436 U.S. 447, 462 n.20 
the Primus Court suggested that a " 'serious danger' of conflict of interest or of organizational interference with the actual conduct of the litigation"-as opposed to actual harm-would justify an infringement. ${ }^{339}$ Under this dictum, the precise question is whether fee-sharing arrangements create a "serious danger" that organizations will create conflicts of interest or attempt to exert control over the actual conduct of litigation, thus justifying state interference without waiting for actual harm..$^{340}$

As an intuitive matter, fee sharing would seem to increase the likelihood of injurious lay interference with the attorney-client relationship because fee-sharing agreements strengthen the incentive for organizations to control litigation. As the Court pointed out in Button: "Objection to the intervention of a lay intermediary, who may control litigation or otherwise interfere with the rendering of legal services . . . derives from the element of pecuniary gain." "341 The Court discounted the danger of conflicts in Button "because no monetary stakes are involved, and so there is no danger that the attorney will desert or subvert the paramount interests of his client to enrich himself or an outside sponsor." ${ }^{342}$ Fee sharing, however, reinstates the missing element of pecuniary gain, and the accompanying danger that the attorney will enrich the sponsor at the expense of the client. Ideological commitment on the part of public interest organizations only heightens the incentives to control litigation. As Justice Rehnquist suggested in Primus, the danger of harm to the attorney-client relationship is not minimized "simply because a lawyer proceeds from political conviction rather than for pecuniary gain." 343

If logic alone were sufficient, this train of reasoning would demonstrate a compelling interest in prohibiting fee sharing with staff attorneys. But logic is not enough. In the group legal services cases, the Court has considered historical or empirical evidence essential to establishing a compelling state interest. In United Mine Workers, for example, the Court struck down a blanket prohibition against hiring staff attorneys because, in the many years the program had been in operation, there had come to light "not one single instance of abuse, of harm to clients, of any actual disad-

(1978) ("We hold today in Primus that a lawyer who engages in solicitation as a form of protected political association generally may not be disciplined without proof of actual wrongdoing that the State constitutionally may proscribe." (emphasis added)).

339. 436 U.S. at 436 (quoting Button, 371 U.S. at 443) (citations omitted, emphasis added). This suggestion was a step toward endorsing Justice Harlan's belief that states could constitutionally employ prophylactic measures to ward off "foreseeable abuses." See United Mine Workers, 389 U.S. at 232-33 (Harlan, J., concurring in part and dissenting in part).

340. See Primus, 436 U.S. at 436-39 (discussing justifications for state regulation of lawyers associated with nonprofit groups).

341. 371 U.S. at 441 (emphasis added).

342. Id. at 443 (emphasis added).

343. 436 U.S. at 445 (Rehnquist, J., dissenting). This ideological commitment motivated the NAACP and the ACLU to exert control over the selection of plaintiffs and attorneys in both Button, see 371 U.S. at 448-50 (Harlan, J., dissenting), and Primus, see 436 U.S. at 416 n.6 (letter to plaintiff). 
vantage to the public or to the profession" growing out of the financial connection between the union and its staff attorney. ${ }^{344}$ If the state cannot produce historical or empirical evidence that fee sharing between lawyers and nonlawyers leads to improper conflicts or control, then the danger of fee sharing with staff lawyers must not be as great as logic suggests, and the state's interest is not compelling. ${ }^{345}$

\section{Precision of Regulation}

Even if the danger to the attorney-client relationship did constitute a compelling state interest, the state would also have to show that a blanket prohibition on fee sharing between staff attorneys and public interest groups regulates with precision-that it is a "carefully tailored regulation that does not abridge unnecessarily the associational freedoms of nonprofit organizations." ${ }^{346}$ The blanket prohibition against fee sharing cannot pass this test because it is overinclusive in the conduct it regulates and does not use the least restrictive means to attack the evil it seeks to eliminate.

The fee-sharing rule is overinclusive because it regulates all types of fee sharing even though some types of fee sharing do not threaten serious evil. Specifically, the rule prohibits fee sharing with cooperating attorneys as well as with staff attorneys, even though only fee sharing with staff attorneys poses any serious likelihood of injurious lay interference with the attorney-client relationship. ${ }^{347}$ Because the rule uses fee sharing as a proxy for evil, even though there is not necessarily any direct connection between fee sharing and injurious interference, the rule sweeps too broadly.

A line of charitable fundraising cases demonstrates that the Court will not tolerate such overinclusiveness in the First Amendment area. In Village of Schaumburg v. Citizens for a Better Environment, ${ }^{348}$ for example, the Court considered a nonprofit advocacy group's First Amendment chal-

344. 389 U.S. at 225 .

345. The state's historical evidence also will have to be directly related to the fee-sharing agreements at issue in a particular case. Otherwise, the evidence might be irrelevant or insufficient. In Trainmen, for example, Justice Clark argued that the past history of the union, including fee sharing and other unethical practices, justified the state's regulation of the union's plan: "[T]his identical union plan has been before several other courts and, while the union has repeatedly promised to reform, as here, it has consistently renewed the same practices." 377 U.S. at 11 (Clark, J., dissenting) (footnote omitted). The majority ignored this argument. In United Transportation Union, Justice Harlan recounted cases from Illinois and Virginia presenting a history of abuses in the union's plan, including the unethical sharing of legal fees. See 401 U.S. at 586-93 (Harlan, J., concurring in part and dissenting in part). The majority brushed off this history, saying that it presented "other cases involving other parties in other courts." Id. at 583.

346. See Primus, 436 U.S. at 439 (noting that Court's opinion should not be read to foreclose such regulation).

347. See supra text accompanying notes 245-51 \& 341-45. Even fee sharing with staff attorneys, however, poses only a hypothetical danger because there is virtually no empirical evidence of injurious lay interference with staff attorneys for public interest organizations. See supra text accompanying notes $344-45$.

348. 444 U.S. 620 (1980). 
lenge to a municipal ordinance that prohibited door-to-door solicitation by organizations applying more than twenty-five percent of their receipts to salaries and other noncharitable purposes. ${ }^{349}$ The Court invalidated the ordinance on its face because a substantial number of groups within the ambit of the statute did not cause any of the evils the state sought to prevent. This broad sweep was unacceptable because the government may not lump together bona fide organizations with fraudulent ones, and "refuse to employ more precise measures to separate one kind from the other." ${ }^{360}$ By analogy, the state may not lump together all forms of fee sharing and refuse to separate the dangerous kinds from the harmless kinds.

The Court used a similar analysis in another charitable fundraising case, Secretary of State $v$. Joseph H. Munson Co ${ }^{351}$ Munson, a professional for-profit fundraiser, ${ }^{352}$ challenged a statute that prohibited charitable organizations from paying anyone more than twenty-five percent of the amount raised in connection with any fundraising activity. ${ }^{363}$ As in Schaumburg, the Court found the statute invalid on its face. The flaw in the statute was "a fundamentally mistaken premise that high solicitation costs are an accurate measure of fraud." 354 The premise that all feesharing arrangements lead to a serious danger of injurious interference with the attorney-client relationship is similarly mistaken.

Even as to those fee-sharing arrangements that do pose a danger to the attorney-client relationship, the fee-sharing rule is invalid because it is flawed by another type of imprecision. It fails to employ the least restrictive means to attack the evil at which it is aimed. This type of imprecision was stressed by the Schaumburg Court, which set down the general rule that challenged regulations are constitutionally flawed, even when supported by constitutionally sufficient government interests, unless the regulations promote the governmental interests directly rather than "peripherally." ${ }^{355}$ After examining the interests allegedly served by the ordinance at

349. See id. at 622 .

350. Id. at 637. The Court implied that states could impose restrictions on organizations that were "using the charitable label as a cloak for profitmaking." Id. The Court supported its analysis with a well-known quotation from Button: "Broad prophylactic rules in the area of free expression are suspect. Precision of regulation must be the touchstone . . . ." Id. (quoting Button, 371 U.S. at 438). The village's ordinance failed this test because it was "insufficiently related to the governmental interests asserted in its support to justify its interference with protected speech." 444 U.S. at 639.

351. 467 U.S. 947 (1984).

352. See id. at 950 .

353. See id. at 950-51. The statute at issue in Munson had greater flexibility than the ordinance struck down in Schaumburg. For example, the Maryland statute allowed a waiver of the $25 \%$ limitation for a charity that could demonstrate financial necessity. For the full text of the challenged statute, see id. at 950 n.2.

354. Id. at 966; see also id. at 961 (discussing Schaumburg). More recently, the Court struck down still another charitable fundraising statute because there was a "missing nexus" between the statutory restrictions and the state's interests. See Riley v. National Fed'n of the Blind, Inc., 108 S.Ct. 2667, 2675 (1988).

355. 444 U.S. at 636 . 
issue in Schaumburg, the Court concluded that the village could further these interests through less intrusive measures. ${ }^{356}$

The state can likewise prevent public interest groups from interfering with the attorney-client relationship through less intrusive measures than a blanket prohibition on fee sharing. The most obvious of these alternative measures is more vigorous enforcement of existing codes of legal ethics, which zealously guard a lawyer's independent professional judgment from outside interference and affirmatively require lawyers to serve their clients loyally. ${ }^{357}$ Another measure would be revising state or federal tax laws to prohibit tax-exempt organizations from exerting pressure on an attorney or client in a sponsored case in order to increase the amount or likelihood of a fee award. ${ }^{358} \mathrm{~A}$ third alternative would be to amend (or enforce) state laws and regulations governing nonprofit corporations and associations so that public interest organizations would be barred from exerting control over the conduct of litigation or interfering with the attorney-client relationship. ${ }^{358}$

These alternatives may be more difficult to enforce than a blanket ban on fee sharing, ${ }^{360}$ but the Supreme Court has emphasized that "the First Amendment does not permit the State to sacrifice speech for efficiency." Consequently, even in purely commercial contexts, the Court has ordinarily rejected enforcement difficulties as a justification for broadly drawn

356. For example, the village's interest in preventing fraud could be served through disclosure requirements and penal laws against fraud, and its interest in public safety was unrelated to the regulation. 444 U.S. at 637-38.

357. See Model Rules, supra note 5, Rule 1.7 comment ("Loyalty is an essential element in the lawyer's relationship to a client."); $i d$. Rule 1.8(f)(2) (requiring lawyer who accepts compensation from ane other than client to ensure that "there is no interference with the lawyer's independence of professional judgment or with the client-lawyer relationship"). See generally Patterson, Legal Ethics and the Lawyer's Duty of Loyalty, 29 EMORY L.J. 909 (1980).

358. See Rev. Rul. 75-76, 1975-1 C.B. 154, 155 (neither expectation nor possibility, however remote, of award of fees may be substantial motivating factor in selection of cases for nonprofit public interest law firm).

359. Cf. Revised Model Nonprofit Corporation Act (ABA Section of Corporation, Banking and Business Law, Committee on Nonprofit Corporations Exposure Draft March 1986) (developing general standards for nonprofit corporations).

360. Enforcing the rules against third-party interference with the attorney-client relationship might be less effective than the fee-sharing prohibition because lawyers seldom report misconduct by other lawyers. See Model Rules, supra note 5, Rule 8.3 comment (Code's requirement in DR 1103(A) that lawyer report every violation of disciplinary rules "proved to be unenforceable"). In addition, clients might not know if a staff lawyer is being improperly influenced. The bar could step up enforcement against lawyers for public interest groups, but most state bars have few well-trained investigators, and many states have too few disciplinary counsel to handle all of the complaints that are deemed worthy of prosecution. See, e.g., Carrizosa, Watchdog Panel's Report Finds Few Discipline Problems, L.A. Daily J., July 21, 1988, at 1, col. 2 ("[T]he bar needs to do more to provide its investigators with better training, more consistent supervision and clearer policies and procedures."); Jost, The Public's Stake in Lawyer Discipline, L.A. Daily J., Apr. 8, 1985, at 3, col. 5 (portraying disciplinary system as "lenient, secretive, and slow"). But see Zazzali, Disciplining Attorneys: The New Jersey Experience, 1 Geo. J. Legal ETHICs 659, 688 (1988) (concluding that New Jersey disciplinary system has been successful in punishing and deterring misconduct).

361. Riley v. National Fed'n of the Blind, Inc., 108 S. Ct. 2667, 2676 (1988). 
prophylactic rules. ${ }^{362}$ The fee-sharing rule does sacrifice speech for efficiency, and thus fails to meet the least restrictive means test.

States can cure the problem of imprecision by writing a new rule that prohibits fee sharing with any organization that exerts control over the actual conduct of litigation or otherwise interferes with the attorney-client relationship. Furthermore, states can continue to seek empirical or historical evidence that fee sharing with public interest organizations leads to improper conflicts or control so frequently that it can be said to pose a "serious danger" to the attorney-client relationship. But under the Supreme Court's consistent jurisprudence in the area of group legal services, a fee-sharing rule that prohibits all fee sharing between all lawyers and all nonlawyer public interest organizations is unconstitutionally imprecise and hence unenforceable.

\section{ConCLuSION}

The wall of separation between lawyers and nonlawyers has been virtually unbreachable for almost a century. Today, the prohibition against sharing fees with a nonlawyer is nearly universal. This prohibition was originally intended to thwart ambulance chasers and to prevent banks and commercial law corporations from transforming the practice of law into an ordinary commercial business, with the resulting unrestricted emphasis on the hard sell and the bottom line. But the organized bar has consistently applied the ban on fee sharing to nonprofit entities.

Nonprofit public interest organizations have made great strides in overcoming statutes and regulations against solicitation and unauthorized practice that stood in the way of organized public interest litigation. Public interest groups have now firmly established their constitutional rights to sponsor and solicit litigation and to recommend or provide attorneys. As

362. In Shapero v. Kentucky State Bar Ass'n, 108 S. Ct. 1916 (1988), for example, the Court struck down a Kentucky rule completely prohibiting lawyers from sending "targeted" letters to potential clients known to need legal services of the type offered by the lawyer in a particular matter. The Court noted that the state could regulate abuses in targeted letters "through far less restrictive and more precise means" than a total ban. $I d$. at 1923. The Court expressly rejected the state's contention that policing abuses in targeted letters would be too onerous:

To be sure, a state agency or bar association that reviews solicitation letters might have more work than one that does not. But "[o]ur recent decisions involving commercial sptech have been grounded in the faith that the free flow of commercial information is valuable enough to justify imposing on would-be regulators the costs of distinguishing the truthful from the false, the helpful from the misleading, and the harmless from the harmful.'

Id. at 1924 (quoting Zauderer v. Office of Disciplinary Counsel, 471 U.S. 626, 646 (1985)); see also Zauderer, 471 U.S. at $644-45$ (rejecting state's argument that legal advice in advertisements may be banned because "it is intrinsically difficult to distinguish advertisements containing legal advice that is false or deceptive from those that are truthful and helpful, much more so than is the case with other goods or services" (footnote omitted)); Bates v. State Bar, 433 U.S. 350, 379 (1977) (rejecting state's argument that "wholesale restriction" on lawyer advertising is "justified by the problems of enforcement if any other course is taken"). But see Ohralik v. Ohio State Bar Ass'n, 436 U.S. 447, 466 (1978) (allowing state to enforce prohibition against in-person solicitation of legal business for pecuniary gain in absence of showing of actual harm, because "in-person solicitation would be virtually immune to effective oversight and regulation" if state were required to prove actual harm). 
yet, however, the Supreme Court has not definitively stated that those constitutional rights encompass the rights of lawyers to share fees with public interest organizations. The time has come to recognize that lawyers ought to have that right.

We live in an era of deregulation. In many spheres, the drive for deregulation has come from the executive branch, the independent agencies, or the legislatures-that is, from traditional sources of rulemaking. In the legal profession, however, the impetus for deregulation has come almost exclusively from the United States Supreme Court. In a series of ten cases on advertising and group legal services spanning a twenty-five year period, the Supreme Court has decided against state bar associations and reversed state supreme courts nine times. This reflects poorly on the organized bar's capacity for leadership. I understand the bar's reverence for the attorney-client relationship and its determination to maintain professionalism among lawyers, and I share those values. But I also believe that the bar should continually reexamine its premises and its rules, especially when those rules jeopardize constitutional rights and values.

The rule against sharing fees with nonlawyers is ripe for reexamination. The Kutak Commission believed that the rule ought to be reexamined in all contexts, commercial as well as nonprofit. The ABA's House of Delegates voted down the Kutak Commission's proposed revision, but my proposed revision is more modest. I propose simply that lawyers be permitted to share legal fees with nonprofit public interest organizations as long as the organizations do not interfere with the attorney-client relationship or otherwise commit the evils at which the fee-sharing rule is now aimed. This express exception to the rule against fee sharing with nonlawyers would further the policies underlying statutory fee-shifting provisions, assist political expression by minorities, and advance the bar's stated goal of making high quality legal services more widely available to those who might otherwise lack representation.

Perhaps in debating and formulating an express exception for fee sharing with nonprofit groups, the bar will conclude that the entire feesharing rule needs to be revised, even in the commercial sphere. Given the weaknesses of the state's policy reasons for maintaining the prohibition against fee sharing, and given the increasing need of clients for a range of services broader than lawyers alone can provide, a searching reexamination of the rule would make sense. ${ }^{363}$ In the meantime, I hope that the courts and bar associations called upon to rule on the question presented in this Article will state unequivocally that lawyers may share legal fees with nonprofit organizations as long as there is no proof of actual harm.

363. For a recent scholarly reexamination of the fee-sharing rule in the for-profit context, see Gilbert \& Lempert, supra note 71, at 383 (discussing North Dakota and District of Columbia proposals to allow nonlawyers to form partnerships with lawyers under limited circumstances). 
